University of New Mexico

UNM Digital Repository

UNM Bulletins

Scholarly Communication - Departments

1908

\title{
Manual of the more common flowering plants growing without cultivation in Bernalillo County, New Mexico
}

\author{
J.R. Watson
}

Follow this and additional works at: https://digitalrepository.unm.edu/unm_bulletin

\section{Recommended Citation}

Watson, J. R.. "Manual of the more common flowering plants growing without cultivation in Bernalillo County, New Mexico." University of New Mexico biological series, v. 3, no. 1, University of New Mexico bulletin, whole no. 49 3, 1 (1908).

https://digitalrepository.unm.edu/unm_bulletin/19

This Article is brought to you for free and open access by the Scholarly Communication - Departments at UNM Digital Repository. It has been accepted for inclusion in UNM Bulletins by an authorized administrator of UNM Digital Repository. For more information, please contact disc@unm.edu. 


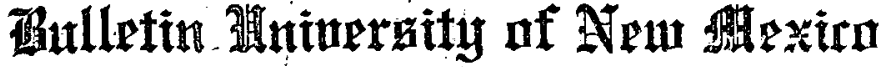

WHOLE NO. 49

Published Quarterly by the University

Biological Series Albuquerque, N. M., December, 1908 Vol. 4 No. 1

\section{Manual of the More Common Flow- ering Plants Growing Without Cultivation in Bernalillo County, New Mexico}

\author{
J. R. WATSON, A. M.
}

Associate Professor in Charge of the Department of Biology

\section{PREFACE.}

This bulletin has grown out of the need, felt by the author, of a key to the local plants to place in the hands of his students. None of the manuals published cover this region satisfactorily. Although very local in its scope and prepared to meet a specific need, it is hoped that it may prove useful to teachers and others in the territory where the altitude and other physiographic conditions are similar to our own.

No claim is laid to completeness but the bulletin will include the vast majority of the common plants of the region exclusive of the glumaceous division of the mono-cotyledons, i. e., grasses, sedges, etc.

Some parts of the county have not been visited, as the Rio Puerco region, and others imperfectly worked. The Manual will doubtless be found more nearly cont

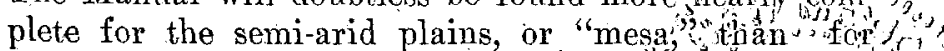
either the valley of the Rio Grande or the mountains. The University is situated on the mesa and naturally that region has received more attention.

The author has in his possession a few isomion plants not as yet identified and conseruenty not in 


\section{WATSON-Plants of Bernalillo, County}

cluded here. That there are other species in this region is certain. This is especially true of the Cactaceae and the genus Opuntia. The author's residence here has been too brief for their satisfactory study, as both blossoms and fruit are required. He is quite sure that there are forms here not described in any of the works at his disposal. In the valley there are likely to ocfur species introduced from the East that have escaped his notice. And it would indeed be strange if soine species were not accidentally overlooked in a hurriedly prepared key. Many species are given in the manuals as occurring in this territory' which doubtless grow in the country, but it has been thought best to limit the present publication to those actually observed, learing to future publications these additions. Most of the species here given have been collected by the author or his students during the years 1907 and 1908, but a number are represented only by specimens in the herbarium collected by former President Herrick, some ten years ago. These were all identified by Prot. Wooton of the New Mexico Agricultural College, to whom also the author is deeply indebted for kindly help rendered him in the identification some of the more puzzling species. With a few exceptions each species is represented by a specimen in the. University Herbarium. It has been thought best to use, in the main, the nomenclature found in Gray's works, Coulter's Rocky Mountain Flora, and Botany of. Western Texas, as these are the works the students will mostly consult for fuller descriptions and other species. The sequence of order's, however, is nearer that of Engler and Prantl in "Planzen-familien." Some references are made to the ecological formations and societies of the region but their detailed treatment as well as the. physiographic and climatic features of the region is reserved for a further publication.

The descriptions and re-arranged keys are necessarily mostly compilations from the works cited above. .."In ${ }^{n}{ }^{\theta}$ conchusion, the author wishes to express his $\therefore$ ideep apjy theciation of the kindly help rendered by the

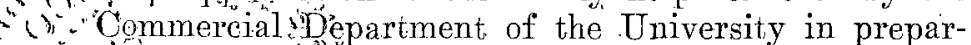
ing the manuseript for the printer. (1)

Biological Lationatory, University of New Mexico, Torembert 16, 1908.

$\because \therefore=$ II

UNIVERSITY OF NEW MEXICO LIBRARY slletin University of New Mexico-No. 49

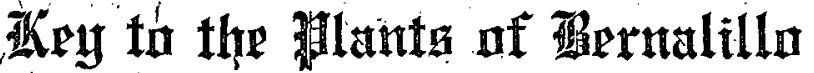 Ornunty, ANew M}

\author{
KEY TO THE ORDERS.
}

CLASS I-ANGIOSPERMS: Plants in which the ovules are contained in a closed ovary.

(Class II on P. XII.)

SUB-CLASS I-DICOTYLEDOUS: Plants whose seeds have two cotyledons; whose fibro-vascular bundies form, a ring in the stem, whose leaves are netveined, and the parts of the flowers are usually in fours or fives or multiples thereof.

(Sub-class on P. XI.)

DIVISION| I-GAMOPETOLAE: Those plants having both calyx and corolla, the latter with petals more or less united.

(Division II on P.V.)

A, Stamens as many as the lobes of the coroli.a AND ALTERNATE WITH THEM, JR FEWER. (B. On P. V.)

$$
\text { 1. Ovary Inferior. }
$$

Stamens united by their anthers into a ring or tube;

Flowers in a head, fruit an achene;

Flowers separate, fruit a pepo

$$
\text { (1) Compositae, P. } 1 .
$$

(3) Cucurbitaceate P. 23.

Stamens separate, free from the corolla or nearly so;

(2) Campanuliaceat P 23

Stamens separate, inserted on the corolla.

1-3, Always fewer than the lobes of the corolla;

4-5, Leaves whorled or opposite.

(4) Valerianean P. 24.

Leaves opposite and with stipules or whorled;

(6) Rubiaceae P. 24.

Leaves opposite and without stipules;

(5) Caprifoliaceate P. 24.

(2) Ovary superior (i. e., free from the calyx.) *Corolla regular.

- Stamens as many as the lobes of the corolla.

Ovaries 2 and separate.

Filaments distinct, pollen as usual;

- (20) Apocynaceat P. 43.

III

69r8:3 
Filaments monadelphous, pollen ị masses;

(19) Ascrepiadiate P. 42.

Ovary single, but deeply 4 -lobed around the common style:

Leaves alternate; - (10) Boragineae P. 29. Leaves opposite, stems squaré

Ovary one, not deeply lobed.

(9) Labiatae P. 27.

1-celled, 1-ovuled, becoming as achene;

(7) Plantagineae P. 25. 1-celled, with more than one ovule.

Leaves entire; - (21) Gentianeae P. 44.

Leaves, Jobed, toothed, or pinnately compound;

- (11) Hydrophyllaceae P. 31.

2 to 10 -celled.

I.eafless parasitic twining plants;

(18) Cucunta in Convolvulaceae P. 42.

Leaves present.

Stamens 4; pod 2-celled Circumscissile;

(7) Plantagingae P. 25.

Stamens 4, ovary 2 to 4-celled; ovules solitary;

Stamens 5 or rarely more.

Fruit of $2-4$ seed-like nutlets;

Fruit a few-seeded pod:

(10) Boragtreate P. 29.

Calyx 5-cleft; style-3-jobed or cleft;

(17) Polemoniaceae P. 39. Sepals 5 ; styles 1 or 2 , entire or 2 -cleft ;

(18) Convolvuiaceae P. 41.

Fruit a many-seeded pod or berry;

(16) Solanaceae P. 37.

( See also Nama in Hydrophyllaceae P. 32.)

- Stamens fewer than lobes of corolla.

Stamens 4, didynamous; (8) Verbenaceae P. 26. Stamens only 2 with anthers; ovary 4-lobed;

Stamens 2 , rarely 3 ; ovary 2 -celled;

(9) Labiatae P. 27.

(7) Plantagineae P. 25

** Corolla irregular; stamens (with anthers) 4 . and didynamous, or only 2 .

Ovules and seeds solitary in the (1 to 4) cells.

Ovary 4-lobed, the style arising from between the

lobes; - - - - (9) Labiatae P. 27.

Ovary not lobed, the style from its apex;

IV
(8) Verbenaceae P. 26. Ovules numerous, or at least as many as 2 in each cell. Ovary and pod 1-celled.

Without green foliage;

- - - - (14) Orabanchaceae P. 33.

With green foliage; (13) Pedalineae P. 33.

Ovary and pod 2-celled, but the 2 placentae parietal; - - - - (12) Bignoniaceae P. 32. Ovary and pod 2-celled; placentae in the axis;

(15) Scrophullarineae P. 34.

B. Stamens (Fertile ones) as many as the LOBEs of TIIE COROLLA AND OPPOSITE THEÁ.

Ovary 1-celled; pod several to many-seeded; style 1.

(22) Pinimulaceae P. 44.

C, Stamens More nUMerous than the lobes of the Corolla; ; - - - (5) Caprifoliaceat P. 24.

Gamopetalous forms in polypetalous orders.

A, Stamens more numerous than the lobes of the corolla.

Ovary 1-celled, with one parietal placenta;

(41) Leguminosae P. 58.

Ovary 2-celled with a single ovule in each cell;

Ovary 3-many-celled.

(35) Polygaleak' P. 55.

Stamens free from the corolla; styles 5, Oxalis in

- - - - - Gerantaceae P. 58

Stamens inserted on the base or tube of the corolla; filaments monodelphous;

- - - - - (28) Maldaceae P. 51.

$\mathrm{B}$, Stamens as many as the lobes of the corolla.

Ovary adherent to the calyx-tube; tendril-bearing

herbs; - - (3) Cucurbitaceae P. 23.

DIVISION II-POLYETALAE: Those that have both calyx and corolla, the latter of separate petals. Div. III on P. IX.)

$\mathrm{A}$, Stamens not more than twice as many as the petals, when just the number then alternate with them. (B. and C. on P. VIII.)

1. Ovary inferior; $i$. e., calyx grow to the ovary or at least to its lower half.

Orules and seeds more than one in each cell.

Ovary 1-celled, many-ovuled from the base;

- - - - (52) Portulaceat P. 80. Ovary 1-celled, with 2 or 3 parietal placentae;

(43) Saxifragaceate P. 70

\section{$\mathrm{v}$.}




\section{WATSON-Plants of Bernalillo County}

Ovary 2 to several-celled.

Stamens on a flat disk which covers the ovary;

(31) Cemastrineate P. 52.

Stamens inserted on the calyx.

Stamens 8 or 4 (rarely 5 ); style 1 ;

(24) Onaigrariene P: 45. Stamens 5 or 10 ; styles 2 or 3 , distinct;

(43) Saxifragace P. 70.

Ovules and seeds only one in each cell.

Stamens 2 or 8 ; style 1; stigma 2-4 lobed;

Stamens 5; styles 2, flowers in umbels;

- - - $\quad$ - $\quad$ - (23) UMrbetififera P. 45.

..2. Ovary superior, $i$. e., wholly free from the. calyx.

* Ovary only one. (** on P. VII:)

- Ovary compourd as shown by the number of cells, placentae, styles or stigmas. ( on P. VII.)

Ovary 2 to several-celled.

Flowers irregular.

Anthers opening at top, 1-celled; ovary 2-celled;

- - - - (35) Polygaleae P. 55.

Anthers opening lengthwise, 2-celled; ovary 3celled; - - (32) Sapindaceae P. 53.

Flowers regular or nearly so.

Stamens neither just as many nor twice as many as petals.

Tetradynamous (rarely 2 or 4 ); petals 4 ;

(46) Coructaerae P. 73.

Distinct and more numerous than petals;

(32) Sapindaceat P. 53

Stamens just as many or twice as many as the petals.

Ovules and seeds only 1 or 2 in each cell.

Herbs; flowers perfect and symmetrical.

Cells of the ovary as many as the sepals and petals; (40) Geraniaceae P. 57. Cells of the divided ovary twice as many as the styles, sepals; etc.; (38) Linachas P. 56.

Shrubs or trees.

Leaves pinnate or 2-foliate, opposite, not dotted. (See also No, 36.)

(39) Zygopmylleae P. 57.

Leaves 3 -foliate, with pellucid dots;

- - (37) Ptelea in Rutaceae P. 56. VI

\section{Bulletin University; of New Mexico-No. 49}

Leaves palmately veined and fruit 2-winged, or pinnate and fruit a berry;

(32) Sapindaceae P.' 53.

Leaves pinnately veined, simple, not dotted with pellucid dots; (31) CELASTRINEAE P. 52.

Ovules (and usually seeds) several or many in each cell.

Stamens 10, monadelphous at base; leaflets 3 , inversely heart shapee;

- - - Oxalis in Gerantaceae P. 58 Stamens distinct, free from calyx;

(50) Cary ophylleae P. 79 Stamens distinct, inserted on the calyx;

Ovary 1-celled.

(43) Saxifragaceat P. 70.

Corolla irregular; petals 4; stamens 6 ;

(47) Fumariaceae P. 75.

Corolla irregular; petals and stamens 5;

- - - - - (27) VIolarieae P. 51.

Corolla regular, or nearly so.

Ovule solitary; shrubs or trees; stigmas 3 ;

(33) Anacardiacéne P. 53.

Ovules more than one, in the center or bottom of the cell; - - (50) CARy ophylieae P. 79.

Ovules sevieral or many, on two or more parietal placentae.

Seeds comose or long-hairy; shrubs or small trees;

- - - (53) Tamariscinea P. 80.

Seeds not as above; (43) Saxrfragaceae P. 70

- Ovary simple, with one parietal placenta, fruit a legume; - - (41) Leguminosae Po. 58. * Ovaries or lobes of the ovary 3-5, with a common style; - (40) Geraniaceae P. 57.

** Ovaries 2-5, somewhat united at the base, separate above.

Leaves dotted with pellucid spots;

(37) Rutaceate P. 56

Leaves not dotted. (See also No. 36. P. 56.)

Shrubs or trees with opposite leaves;

- - - (32) Sapindaceae P. 53

Terrestrial herbs; the carpels fewer than the petals; - - (43) Saxifragaceae P. 70 **** Ovaries 2 or more, separate.

VII 
'WATSON-Plants of Bernalillo Counly

Stamens free from the calyx.

Leaves punctate with pellucid dots;

- - - - - (37) Rutaceae P. 56.

Leaves not pellucid-punctate. (See also No. 36, P. 56.)

Herbs not fleshy;

- - - (49) Ranuńculaceae P. 76 Herbs with thick, fleshy leaves;

$$
\text { - } \because \text { (44) Crassulaceat P. } 72 .
$$

Stamens inserted on the calyx.

Just twice as many as the pistils;

(44) Crassulaceae P. 72

Not twice the number of the pistils.

Leaves without stipules;

(43) Saxifragaceae P. 70.

Leaves with stipules; (42) Rosaceat P. 66.

$\mathrm{B}$, Stamens of the same number as the petals and opposite them.

Ovary 1-celled.

Sepals 6 ; stigma 1 ; anthers opening by uplifted vales;

(48). Berberideae P. 76.

Sepals 2 ; stigma 3 ; anthers not so opening;

- - Portulaceae P. 80.

Ovary 2-4 celled.

Calyx lobes minute or obsolete; petals valvate;

- . (29) Ampeitidaceae P. 52.

Calyx 4-5 cleft, valvate in the bud; petals in-

volute; - - (30) R RamneaE P. 52.

$\mathrm{C}$, Stamens numerous, at least more than 10 , and more than twice the sepals or lobes of the calyx.

1. Calyx more or less coherent with the surface of the compound ovary.

Ovary 2-5 celled.

Leaves alternate, with stipules;

- - - (42) Pomgae in Rosacae P. 67.

Leaves opposite, without stipules;

- - - (43) Saxifragaceae P. 70.

Ovary 1-celled, with the orules parietal.

Fleshy plants with no true foliage; petals many; (26) Gactaceat P. 48.

Rough leaved plants, petals 5 or 10 ;

(25) LOASACEAE P. 48

Ovary 1-celled, with the ovules rising from the base;

(52) Portulaceae P. 80.

(2) Chlyx entirely free and separate from the pisVIII
Bulletin University of New Mexico-No. 49

til or pistils.

Pistils numerous, separate, but concealed in a hollow receptacle; - - Rosa in-Rosaceae P. 66.

Pistils more than one, separate, not inclosed in a hollow rectacle.

Stamens inserted on the calyx, distinct;

(42) Rosaceae P. 66 Stamens united with the base of the petals, monadelphous ;

(28) Malvaceae P. 51. Stamens inserted in the receptacle;

(49) Ranunculaceae P. 76.

Pistils several, their ovaries cohering in a ring around the base of the axis; (28) Malvaceae P. 51.

Pistils strictly one as to ovary; styles or stigmas may

be several.

Ovary simple, 1-celled, 2-ovuled;

- - - - (42) Rosaceae P. 66 Ovary compound, 1-celled, with a central placenta; - - (52) Pontulaceae P. 80. Ovary compound, 1-celled, with two or more parietal placentáe; - (45) Capparideae P. 72. Ovary compound, several-celled;

(28) Malvaceae P. 51.

Polypetalous forms in gamopetalous orders

Stamens not more than twice as many as the petals, when just the number alternate.

Ovaries 2 or more, separate; stamens united with each other and with a large and thick stigma common to the two ovaries;

(19) Asclepiadaceae P. 42.

DIVISION III: APETALAE: Those with one set of floral envelopes only, or none.

A, Flowers not in catkins.

1. Pistil one, either simple or componmd.

Ovary wholly inferior, 1-celled.

Parasitic on the branches of trees; anthers sessile; (58) Lorantiaceae P. 86. Not parasitic above ground; anthers on filaments; (59) Santalacean P. 87.

Ovary free from the calyx, but permanently invested by its tube (or the base of it) so as to seem inferior; herbs with corolla-like calyx;

(54) Nyctagingate P. 80.

Ovary plainly free from the calyx, which is something wanting. 


\section{WATSON-Plants of Bernalillo County}

Stipules sheathing the stem at the nodes;

(57) Polygonacene P. 85.

Stipules not sheathing the stem, or none.

Herbs.

Ovary 3 (rarely 1 or 2 ) celled; juice milky;

- - - (34) Euphorbiaceate P. 54.

Ovary 1-celled; juice not milky.

Style (if any) and stigma only one; leaves simple; no searious bracts around flowers; - - (60) Urticaceae P. 87. Style 3 ; flowers involucrate-Eriogonum in

(57) Polygonacteate P. 85. Styles or stigmas 2 or 3 .

Stipules none; flowers with scarious bracts; (56) Amarantilaceae P. 84. No stipules nor scarious bracts;

- Cfienopodiaceae P. 82. Shrubs or trees (60) Urticaceat P. 87

(2) Pistils more than one, distinct or mearly so.

Flowers naked, perfect;

- - - (63) Piperaceae P: 90.

B. Flowers monoecious or dioecious, one or both $\}$ sorts in catkins.

(1) Only one sort of flower in catkins or catkin-likeheads.

Fertile flowers in a short catkin or head;

- - - . (60) URticachat P. 87.

Fertile flowers single or clustered; sterile in

slender catkins; - (61) Cupiliferas P. 88.

(2) Both sterile and fertile flowers in cathins.

Ovary and pod 1-celled, many-seeded; seeds furnished with a downy tuft at one end;

(62) SALicineati P. 88

Ovary 1 or 2 -seeded, only one ovule in each cell; fruit 1 -seeded.

Parasitic on trees; fruit a berry;

(58) Lorantihaceae P. 86.

Trees or shrubs, not parasitic.

Calyx 'regular, succulent in fruit:

- - - (60) Urticacteate P. 89. Calyx none, or rudimentary and scale-like; (61) Cupuliferae P. 88 .

Apetalous forms in polypetalons orders.

(A) Ovary or its cells containing inany ovules.

Ovary and pord superior.

$\mathrm{x}$.

\section{Bulletin University of New Mexico-No. 49}

3-celled and 3-valved, or 3 to 5 celled and circumscissile (51) Ficordeae P. 79. 2-celled or 1-celled; placentae central;

- - - - (50) Caryopirylleae P. 79. 1-celled with one parietal placenta;

(49) Ranunculaceae P. 76.

Ovaries 2 or more, separate, simple;

(49) Ranuncoraceate $P$. .

(B) Ovary or its cells containing 1 or 2 (rarely 3 or 4 ) ovules.

* Pistils more than one and distinct, or nearly so. Stamens inserted on the calyx; leaves with stipules;

- - - - - (4) Rosacene P. 66

Stamens inserted on the receptacle; calyx present and usually colored or petal-like;

- - - $^{-}$(49) Ranunculacean P. 76. * Pistil 1, either simple or compound.

Ovary free from calyx which is sometimes wanting, shrubs or trees.

Ovules, a pair in each cell of the ovary; fruit 2-celled, a double samara;

Aceringae in Sapindaceae P. 53.

Ovule single in each of the (3) cells of the ovary;

(30) Ruamneat P. 52.

SUB-GLASS II. Monocotymenonae; Plants whose embryos have a single cotledon, no regular bark-wood and pith, but fibrovascular bundles are distributed irregularly, leares are mostly parallel-veined, flowers usually on the plan of 3 , (never 5).

A. Petaromeous Diviston; Flowers not collected on a spadix, with calux and often corolla, either. herbaceous or colored and petal-lite (excopt in Juncaceae).

1. Parianth adherent to the whole surface of the ovary.

Stamens only on one or two; flowers irregular;

- - - - - (64) Orcinddeat P. 90.

Stamens 3, flower regular; - (65) Irideat P. 91. 2. Perianht wholly free from the ovary.

Pistils numerous or few in a head.or ring;

(71) Alismactá P. 94

Pistil 1, compound (cells or placentae mostly 3 ). 
Perianth not glumaceous or chaffy;

- - = - (66) Liliaceae P.91. Perianth wholly glumaceons, of 6 similar division;

B. Glumaceous Division; Flowers destitute of proper parianth, but covered by scale-like bracts or glumes.

Glume a single scale-like kract with a flower in its axil ;

(64) Cyperaceae not included.

Glumes in pairs, one larger:

(70) Gramineae not included.

C. Spadiceous Division; Floweprs collected on a flesy axis (Spadix) or sometimes scattered, mostly destitute of calyx, corolla or glumes.

Little floating aquatics, with no distinction of stem and foliage; - - (68) Lemnaceae P. 94.

Immersed aquatics, branching and leafy;

- - - _ _ (72) Natadaceae P. 95

Reed or flag-like marsh herbs, with linear leaves and flowers in spikes or heads; (73) Typhaceae P. 95.

CILASS II. GYMNOSPERMS: Plants whose ovules are not borne in a closed ovary; Monoecions or dioecious trees or shrubs.

Male flowers in aments ; fernale sub-solitary; nearly naked dioecious shrubs; (74) GETACEAE P' 95.

Female flowers in aments, becoming dry cones or berries; shrubs or trees with needle or scale-like leaves;"evergreens; - (75) Coniferae P. 95.

\section{Manual of the More Common Flower- ing Plants Growing Without Cultiva- tion in Bernalillo County, New Mexico}

\section{COMPOSITAE, (COMPOSITE FAMILY)}

Flowers in a dense head surrounded by a leaf or scalelike involucre. Often of two kinds; showy marginal (ray or ligulate flowers), and less cospicuous disk or tubular flowers. (If there are no ray flowers the head is said to be . disc.. \%.) Ovary one-ovuled, 1 -seeded, becoming an achene, usually surmounted by the calyx, called pappus, consisting of scales or hairlike (capillary) bristles. Some times there are scale or leaf-like bracts among the flowers-chaff.

'Tribe 1. eUpatoriaceat---Heads discoid, Flowers never yellow.

Involucral bracts not herbaceous, in several series, nerved conspicuously when dry, (1) BRICKELLIA.

Involucral bracts somewhat herbaceous or partly colored, inconspicuously or not at all striate, leaves entire,

(2) LIATRIS.

Tribe II. asteroideae. Heads radiate or discoid; style-branches of fertile flowers flattened and with a distinct rough appendage; leaves mostly alternate and receptacle without chaff.

*Ray-flowers yellow, sometimes none. 
Pappus not composed of numerous bristles but of several short chaffy seales, - (3) GUTterRezra.

Pappus of numerous slender bristles, double, outer of very small chaffy bristles. Heads many-flowered with numerous rays, - - - (4) cHRYsopsis.

Simple papus.

Heads many-flowered, many rays,

$$
\text { - - - - - - - - - (5) aplopappus. }
$$

Heads 3-30 flowered, no rays (6) BIGELovia.

Heads few to many-flowered, rays

$$
\begin{aligned}
& \text { 1-6 }- \text { - }-\overline{-}-(7) \text { soldDago. } \\
& \text { * Ray flowers white, blue; or purple, never } \\
& \text { yellow. }
\end{aligned}
$$

Pappus of both disk and ray flowers short crown of scales, - - _ - (8) aPHANOSTEPHUS.

Pappus of several short chaffy bristles and usually 2 (rarely 3 or 4 ) elongated rigid ones,.. . . ..

$$
\text { - }- \text { - - - - - - - (9) Boltonia. }
$$

Pappus of disk flowers of long hair-like bristles.

That of rays none or a mere vestige, (10). PsiLACTrs:

That of rays similar to disk,

Heads on leafy peduncles, bracts of involucre unequal, pappus simple, copious, (11) AsTer. Heads on naked peduncles involucre of narrow equal bracts, pappus rather scanty,

(12) ERIGARON

That of the ray chaffy, or a single series of long awns or coarse and rigid bristles,

**Rays none; heads dioecious (all pistillate or all staminate).

Heads many-flowered; pappis capillary; shrubs,

(14) BaCcharis.

Tribe itI. InUloIdene. Heads discoid; anthers sagittate, the basal lobes with long tails; pappus capitlary or nome.

Heads dioecious,

(15) anténNatira.

Tribe iv. NeItANTHOIDEAE. Heads radiate or discoid, involucre not thin and papery; receptacle chaffy; pappus never capillary, sometimes nome.

* Heads radiate, the ray pistillate and fertile, the disk perfect but sterite.

Involucral bracts in $2 \mathrm{rows}$, the inner embracing or inclosing the ackenes; no pappus,

\section{- (16) MELAMPODIUM.}

Involucral bracts. not inclosing or embracing the achenes.

Achenes wingless, 5-12 in one row, no pappus, (17) BERLANDIERA.

Rays 5, very short, persistent; pappus of 2 small scales, involucral bracts short, in 2 rows,

(18) PaRTHENIUM.

*:Fertile flowers 1 to 5 , the corolla none or a mere tube; staminate corolla funnel-form; no pappus; heads of 2 sorts on the same plant, the staminate with an open cup-shaped involucre, the pistillate in an closed burlike involucre.

Bracts of staminite involucre united, receptacle low.

Involucre armed with 4-8 tubercles or short spines in one row (19) aMBRósta.

Involucre bur-like, armed all over with the spines - - - (20) Franserta. Bracts of staminite involucre distinct, receptacle cylindraceous, - $\quad-\quad$ - (21) XanthidM. ***Ray flowers ligulate and fertile, the ligule persistene on the achenes and becoming papery; leaves opposite and heads singly terminating. stems or branches, (22) ZININIA.

****Heads radiate or rarely discoid, the disk flowers all perfect and fertile; anthers blacloish; pappus none or 1 or 2 chaffy awns.

Receptacle from conical to columinar.

Rays few, neutral, achenes flattened and mar- gined, - - - (23). lepachys.

Receptacle from flat to convex; achenes not very flat, nor winged, nor margined.

Pappus none or a minute denticulate ring - - - (24) GYMNolomis. Phappus deciduous, of two thin scales

(25) FELIANTHUS.

Receptacle flat or convex; achenes of disk either flat or margined or edged or winged.

Achenes 1 to 3-awned; leaves apt to be decurrent, (26) VERBESINA.

*****Rays usually wanting, at least neutral.

Receptacle flat, leaves opposite; inner involucral bracts a cup, - - $(27)$ THetesperma.

Tmibe. . v: hemanioizar. Nearly as in last tribe, but receptacle not chaffy (except 33) and herbage. often covered with dots (glands.)

(3) 


\section{WATSON-Plants of Bernalillo County}

*Involucre of narrow, equal, erect bracts, herbage nore or less white-wooly; no glands, ligules persistent.

Bracts very woolly on back; no pappus (28) BAILEYA. * Ligules not persistent on the achenes; disk flowers numerous; 'no oil glands; leaves alternate in ours.

${ }^{8}$ Receptacle flat or convex, achenes form linear to obpyramidal, rarely 5-angled, occasionally with intermediate nerves; flowers all fertile.

Bracts of involcre wholly herbaceous and flat; corollalobes short; pappus of several scarious scales, (29) BAHIA.

Bracts mostly appressed, with thin, dry and usually colored tips; ray flowers none; leaves alternate.

Pappus of 15 to 20 thin, dry, colorless, obtuse scales,

(30) HYMNENOPAPPUS.

Pappus of 6-12 equal scales, with a strong midrib running thru the entire length

roReceptacle convex to oblong. - (31) POLYPTERIs. ribbed or angled, mostly silky-villous or hirsute;

No awn-like hairy bracts on the receptacle,

$-\quad-\quad-\quad-\quad-\quad-\quad-\quad$ (32) ACTINELLA.

With awn-like 'hairy bracts on the receptacle - - - - (33) gaillardia.

***Involucre of the small heads of a few equal united bracts in one row; leaves apposite; no oil-glands

Heads several flowered, pappus none, one ray

****- - - - - - (34) FLAVERIA. glands

Style branches of perfect flowers long

Bracts of involucre generally united at base only or with some loose bracts, rays few and inconspicuous, $\quad-\quad-\quad-\quad$ (35) Drsodra.

Involucre united into a single cup; rays oblong - - (36) HYMENATHERUM.

Style-branches of perfect flowers very short.

Bracts of involucre in one row, keeled (37) PICTIs.

Tribe vi. Ainthemineaf: Distinguished from the two preceding tribes by the more or less dry and papery bracts; pappus none; leaves alternate.

Receptacle chaffy; heads with rays, (38) achill.eA. Receptacle naked; heads discoid, (39) artemersia.
Bulletin University. of New Mexico-No. 49

TRIBE VII. SENECIONIDEAE. Involucre little or not at all imbricated nor papery; pappus capillary.

Involucre of united, erect, green, equal bracts. Pappus of short copious hairs; leaves alternate, corollas yellow,

(40) SENECIO.

TRIBE viIr. oxnariodeat. Discoid; involucre much imbricated; pappus bristley; leaves alternate. Leaves prickly; pappus plumose - (41) cNIcus.

TRIBE IX. CICHORIACEAE. Receptacle naked or chaffy; herbs with milly juice, and alternate leaves; corollas all ligulate, no tubular ones.

*Pappus of scales and bristles, or plumose, in ours.

Involucre double, calyculate; flowers pink or rosecolor, - - - - (42) STEPHANOMERIA. * Pappus composed entirely of capillary bristle not plumose.

Achenes not flattened, columnar or terete.

Achenes not beaked flowers yellow, pappus tawny, - - - (43) HIERACIUM.

Achenes beaked; flowers yellow; involere calyculate.

Scapose; pappus white and copious,

- - - - - (44) TARAXACUM.

Scapose or branched; pappus reddish, the base surrounded by a soft villous ring, - $1-$ - $^{-} \quad-(45)$ PYRRHOPAPPUS.

Achenes flat or purplish; pappus white, fine an soft; involucre inbricated, leafy-stemmed, heads

panicled, - $\quad$ - $\quad$ - $\quad-\cdot$

(46) sonchus.

Leaves all opposite or some alternate, veiny. Heads white, ochrolencous or even flesh colored.

B. GRANDIFlORA, Nutt, Puberulent or almost glabrous; stem 2 or $3 \mathrm{ft}$. high, paniculately branched; heads 30-40 flowered, 1-2 to 2-3 in. long; drooping; leaves slender-petioled, at least the lower ones opposite, broadly or narrowly deltoid-cordate, coarsely dentate-serrate and with an entire gradually acuminate apex, the larger 4 in. long; pappus white; perennial herbs. On the top of the Sandia Mits. especially on the southern end.

2. ITATIS, Schrel BLAziNg STAR.

Perennial herbs, often dotted with resin; unbranched stem from a roundish tuber; rigid, alternate, narrow, entire, leaves; discoid heads of pretty rose-purple flow-

(5) 


\section{WATSON-Plants of Bernalillo County}

ers; naked receptacle; corolla with long and slender lobes; pappus of $15-40$ hair-like bristles, very plumose in ours.

L. PONCTata, Hook. Stout 10 in. to 30 in. high heads usually many in a dense spike, 3-6 flowered.

In the Yellow Pine Soc. 1 or 2 miles west of camp Whitcomb, late summer or autumn.

\section{(3). GUTJERREZIA, Lag.}

Herbs, but somewhat woody at base; with narrow, small linear, entire leaves; heads small, radiate, yellow. Often called "Golden-rod." Bloom in late summer and autumn.

G. SAROTHRAE, Britt and Russy. Bushy, 6 to 20 in. high; leaves numerous, $1-2$ to 1 in. long; 3 or 4 ray flowers and as many disk flowers in a head. he most common plant on part of the mest and well distributed everywere.

G. FILIFolia, Green. With longer (1 in.) leaves, Mts. and Mesa

4. chrrsopsis, Nutt. (Golden Aster.)

Chiefly perennial, low, woolly or hairy herbs; heads rather large, on ends of branches, vellow; flat receptacle; obovate achenes; pappus double, the outer of very short and somewhat chaffy bristles, the inner long and capillary.

c. vILLOSA, Nutt. Very hairy; stems corymbosely branched, each branch terminated by a head with a short peduncle; leaves narrowly oblong. Common in the grassy patches on the tops of the Sandis Mts.

5. APLOPAPPUS, Cass.

Herbaceous perennials with alternate leaves, hemispherical involucre of many usually closely imbricated bracts in several series, flat receptacle, short-turbinate to linear achenes, and a simple pappus of numerous unequal bristles. In ours heads are from 6-12 $\mathrm{mm}$. high '(1-4-1-2 in.) leaves more or less pinnatified with teeth and tips commonly bristle-tipped.

Leaves not deeply cleft......A. rubiginosa.

Leaves 1 to 2-pinnatifid.......A. spinulosus.

A. RUBIGInosa, Torr and Gray, Viscid, and more or less pubescent 1 to $3 \mathrm{ft}$. high; leaves lanceolate or narrowly oblong; heads 1 to $2 \mathrm{in}$. high or less, usually. on a naked peduncle.

A. Spinduosts. $D C$. Perennial canescent to glabrate, branched at summit; leaves wit sharp pointed
Bulletin University of New Mexico-No. 49

lobes, heads about 1-3 in. high with 15 to 30 rays, bracts wholly appressed; achenes compressed. Common everywhere, especially on the Mesa. In bloom from May to November.

5. BIGELovia, DC. (Rayless Golden-Rod.)

Perennial plants, shrubby at base, few-flowered involucre or rigid somewhat glutinous, closely imbricated and appressed bracts; narrow receptacle, slender or somewhat obconical achenes.

Heads 3 ta 5 flowered.......... B. Bigelovii.

Heads. 7-15 flowered 1-3 to 1-2 in. high, B. Wrightii

B. BIGELOVII, Gray. Canescent with fine close hairs when young, glabrate shrubby, 1-3 ft. high; rigid leaves nearly filiform; heads 1-2 to $2-3$ in. high, involucre bracts lanceolate, acute, thinnish, all pale, imbricated so as to form 5 conspicuous vehtical ranks, 5 or 6 in each rank; achenes and ovaries glabrous. Common on the Mesa and in the sandy parts of the valley.

B. WRIGHTII, Gray. Herbacceous to the woody base, the steml rather slender, 1-3 ft. high; leaves narrowly linear, mostly entire; heads usually numerous and crowded in a corybiform cyme; involucral bracts greenish at or near the apex.

7. solmbago. L. (Golden-Rod.)

Perennial herbs with mostly wand-like stems, nearly sessile leaves which are never heart-shaped, heads small, racemed or clustered, flowers yellow.

*Heads mostly large, many flowered, forming an erect terminal thyrsus; leaves featherveined, numerous, short, sessile, entire, uniform in size and shape.

s. BIGoLoviII, Gray. Somewhat puberulent; leaves oblong or oval, obtuse at both ends. High up on the Sandia Mts. Bear Canon.

**Heads small or middle-sized, in a compound or rather broad thyrsus, not in a terminal corymbiform cyme.

¿Leaves veiny not 3-ribbed, but obscurely triple-nerved sometimes:

s. spectabiuIs, Gray. 1-2 ft. high; heads numerous; cauline leaves lanceolate, or the small uppermost becoming linear, acute; lower and radical spatulate, lanceolate or. oblong, acutish or obtuse, often an inch wide, radical rarely have a few teeth; rays 8-15 small; achenes pubescent. Bear Canon.

(7) 


\section{WATSON-Plants of Bermalillo County}

${ }^{88}$ Leaves more plainly 3-ribbed; heads in onesided spreading or recurved racemes, forming an ample panicle.

s. CANADENSIS, Var aRizonica. Stems tall, rough and hairy, 3-6 ft. high; leaves lanceolate, pointed, sharply serrate, more or less pubescent beneath and rough above; heads small; rays very short. Common along the irrigation ditches, in the valley.

***Heads in a compound terminal corymb, not at all racemose; leaves mostly with a strong mid-ribbed not 3-nepved.

s. RIGIDA, L. Rough and somewhat hoary; stem 1 to $5 \mathrm{ft}$. high, stout, very leafy; leaves oval or oblong, copiously feather-veined, thick and rigid, the upper closely sessile by a broad base, slightly serrate, the uppermost entire; head large, over 30 flowered; rays 7-10. On "Rim Rock" Sandia Mts., in the Yellow Pine Society.

8. APHanostepHu', D. C. (Spreading Daisy.)

Leafy stemmed branching pubescent herbs with solitary terminal daisy-like heads, white to violet-purple rays; broadly lanceolate involucral bracts in few series (the outer shorter); prismatic achenes broad apex with a short crown of scales, cliate-fringed in ours.

A. HUMnLIs, Gray. Low and spreading; leaves rarely entire, often pinnatifid. Very common in the Sandia Mts. Occasionally on the Mesa.

\section{BoLtonia Liher.}

Pale, gree $^{\mathrm{n}}$ and aster-like herbs wit thickish chiefly entire leaves, white or purplish pistillate rays and yellow disk, many-flowered heads, bracts of the hemispherical involucre appressed and imbricated somewhat in two rows, with narrow: membramaceous margins, conical or hemispherical, naked receptacle and very flat obovate or inversely heart-shaped achenes margined with a callous wing (or in the ray 3 -winged) and crowned with a pappus of bristles and awns.

A plant of the mountains seems to belong here but I can not find the species.

\section{PSILACTIs; Gray.}

Annuals with slender branching stems, small heads, on the ends of branches with violet or white often sterile rayjs, bracts of the hemlispherical involucre imbricated in 2-3 series with herbaceous tips, on the outer wholly herbaceous; achenes narrow; pubescent.

\section{Bulletin University of New Mexiço-No. 49}

p. Asteromes, Gray. (Aster-like P.) Covered with a few course hairs, 1-3 ft. high; lower leaves spatulate or oblong, sometimes laciniate---pinnatifid, sometimes barely dentate; uper mostly linear and entire, involucral bracts lanceolate or linear. In sandy fields towards Isleta. Not common. July.

$$
\text { 11. ASTER, } L \text {. }
$$

Mostly perennial herbs, with heads in corymbs, panicles, or racemes; white, purple or blue fertile rays and yellow disk often changing to purple with age, many flowered heads, involucral bracts with leaf like tips; flat receptacle; more or less flattened achenes.

- I. ASTER PROPER. Involucral bracts imbricated, with herbaceous or leaf-like summit. or the outer entirely foliaceous; rays numerous; pappus simple, soft and nearly uniform; achenes flattened.

*Without heart-shaped petioled leaves, the radi cal and lower all acute or. alternate at base; glandular or viscid or silky---canescent.

8Smooth or slightly hairy, involucral bracts closely imbricated, firm and whitish, coriaceous below, leaves entire or at least the upper linear:

A. ERICOIDEs, $L$. The simple branchlets racemose along the upper side of the wand-like: spreading branches; 1-3 ft. high, lowest leaves oblong-spatulate, sometimes toothed, heads 1-4 in. high or less. Occasional along the acequias.

88 Hoary pubescent or hirsute; herbaceous tips of the involucral bracts squarrose or spreading; cauline leaves small, linear, entire; heads numerous, smaill, racemose.

A. moltiflonds, Ait. $1 \mathrm{ft}$. high or less, much branched and bushy; the heads much crowded on the spreading racemose branches; leaves rigid, crowded, spreading with rough or ciliate margins, the uppermost passing into spatulate, obtuse bracts; heads 1-6 to 1-4 in. long; rays white or rarely. bluish, 10-20. Mesa, etc. occasional; usually very short and small on the Mesa.

888Involucre imbricated, not squarrose, but sometimes the outer bracts are loose and: herbaceous and as long as the inner, thin, mostly acute, tip.not -broadened; heads thyrsoid or open paniculate. 


\section{WATSON-Plants of Bernalillo County}

A. Hesperius. (Western Aster.) Tall, 3-8 ft. from nearly glabrous and smopth to scrabrous-pubeiscent; leaves lanceolate, entire, or the larger with a few teeth, 2-5 in. long, about 1-2 in. wide, sessile bit not cordate or auriculate; heads rathei crowded. 4-5 lines high; rays white or violet, $1-2$ to $1-4$ in. long: In the valley.

2. IANTHE. Pappus somewhat double, outer shorter; involucral bractis well imbricated, appressed, without herbaceous tips; rays viclet, achenes narrow, villous; leales unmerous rigid, small linear; 1-nerved and veinless.

A. ERICAEFOLIUS, Rothrock. Low canescent or rough-haired, much branched, bránches erect or diffuse, terminated by somewhat pedunculate small and narrow heads 1-4 to 1-3 in. high); leaves erect or little spreading 1-4 to 1-3 in. long; leaves spatulate, upper linear or nearly filiform; involucral bracts lanceolate, acute or apiculate, thinnish. Quite common on the Mesa as early as April.

-3 ortvomeris. Pappus simple; involucral bracts imbricated, appressed, no herbaceous tips, often scarious-edged or dry; involucre and herbage smooth and glabrous, woody.

A. Spinosus. Benth. Base of stem usually woody, sending up slender and lithe striate green branches, 2-4 ft. long, branching paniculately and terminated by small heads; stem leaves small, more or less fleshy, linear or spatulate-lanceolate, entire, mostly few and fugacious, some of them with soft subulate spines in or above their axils, those of the branchlets reduced to subulate scales or wanting; involucre 1-6 in. high, of subulate lanceolate bracts. Quite common in the sandy fields in the valley. Not so common on the Mesa.

.... 4. MACHAERANTHERA. Involucre imbricated in many rows; the bracts linear, coriaceous, with foliaceous spreading tips; the rays numerous and conspicuous, violet or bluishpurple; pappus copious simple, of rather rigid and unequal bristles; leafy-stemmed and branching, the showy heads terminating the branches, the involucre canescent or even viscid.

*Involucre densèly hispidulous as well as viscid very squarrose, achenes glabrous or glabrate; leaves from incisely dentate to entire, the
Bulletin University of New Mexico-No. 49

teeth hardly at all bristle-tipped; rays bright violet.

A. BIGELOVII, Gray. A foot or two high, robust, stem leafy, branching above, rough-hirsute to glabrate; the flowering branches or peduncles glandular, hirsute, terminated by large showy heads; leaves oblong or lanceolate, irregularly dentate; radical lanceolate-spatulate; cauline oblono to lanceolate, usually with broadish partly clasping base; rays very many, an inch or less long. In the valley near Atrisco.

**Ivolucre from nearly glabrous to glandularpuberulent, but not hispidulous, achenes narrow, densely canescent; leaves generally with bristle teeth.

a. Canescens, Pursh. A foot or two high and loosely much branched, numerous heads in a panicle, canescent or glabrate; leaves lanceolate to linear or the lower spatulate, from entire to irregularly dentate or occasionally laciniate; bracts of involucre rigid, well imbricated; rays violet, 1-3 to 1-2 in. long.

12. erigeron, $L$. Flebane. Daisy.

Herbs with entire or toothed and generally sessile leaves, heads solitary or corymbed, yellow disk, white or purple, very numerous and slender rays, flat or convex naked receptacle; flattened, usually pubescent, and 2-nerved achenes.

Perennials

From a rootstock, leaves entire, pappus double; A foot or two high, exterior pappus minute, - - - 5. MACRANTHUS. Low, exterior pappus, plain, seen as scales, Rays 40 to 50 , diffusely branched;

- - - - - E: BIGELOVII.

Rays 50 to 80 rarely lacking, sparingly branched, - - - E. concrnnus.

From rosulute offsets borne on apex of creeping rootstoeks, leaves serrate pappus quite simple,

Annuals or sometimes biennials

E. Philadelphious.

Rays very numerous (about 100), narrowE. DIVERGENS.

Rays not as numerous nor narrow, E. STRIGosus.

E. Macranthus, Nutt. Leafy stemmed, from hirsute pubescent to nearly glabrous; leaves rather large but upper small, from lanceolate to ovate, entire; in- 
volucre glabrous or nearly so, but often minutely glandular; heads rather large, rays about $100,1-2$ in. long. A handsome species, looks like Aster nova-anglica of the East. Occasionally on the Mesa, in t'e mountains, and towards the Volcanoes.

-B. BIGELovi, Gray. Cinerous-hispidulous, leafy up to the scattered heads; leaves small, spatulate-lanceolate or upper linear; involucral bracts rather rigid, lanceolate, acuminate, of 2 or 3 lengt! is; rays purpleviolet, 1-4, in. long. Oiter pappus of eipnder subulate scales about 1-3 as long is the innei bristice. Bear Cazon. May.

E. Cancinnus, Torr ar d Gray. With dense and shaggy hairs, rays violet to blue rarely white; leaves as in last. On the south end of Rimi Rock. August.

E. PHILAdelipicus, L. Soft hirsute 1 to $2 \mathrm{ft}$. high; leaves oblong or lowest spatulate or obovate, upper half clasping, sparingly and coarsely serrate or entire; rays pink, about 1-4 in. long. 'In alkali and moist soil along the Rio Grande. June.

e. Divergens, Torr and Gray. Diffusely branched and spreading, cinerous-pubescent or hirsute; leaves linear-spatulate, lower broader (1- to 1-4 in.) and sometimes lacinately toothed or lobed; heads 1-6 to 1-4 in. high, rays white, purplish, or sometimes violet; involucre hirsute. Bear Canon. Late summer.

E.. STRIgosus, Muhl. Daisy Flebane. Stem panicledcorymbose at the summit, roughish like the'leaves with minute appressed hairs, or almost smooth; leaves entire or nearly so, the upper lanceolate, scattered, the lowest oblong or spatulate, tapering into a slender petiole; rays white, twice the length of the minutely hairy involucre, outer pappus a crown of minute scales, the inner deciduous fragile bristles, usually wanting in the ray.

\section{TOWNSENDIA, Hook}

Depressed or low many stemmed herbs, much like Aster and Erigeron; entire leaves from linear to spatulate; heads comparatively large; the numerous rays from violet or rose-purple to white; akene commonly beset with hairs which are forked or glochidiate-capitate (i. e. bidentate at top and the two lobes recurved). Bracts of involucre conspicuousty attenate-

acuminate - $-{ }^{-}-$T. ExIMIA $^{-}$ Bracts of involucre not consicuously attenate-

(12) acuminate; heads smaller.

Heads from 1-3 to 3 in. long, sessile, T. SERICEA.

Heads smaller 1-4 in. high, exclusive of

the rays, mostly short pedunculate, T. sTRIgosa.

т. Eximia. Gray. Caulescent, stem erect, simple or sparingly branched, 6-14 in. high, somewhat hirsutepubescent, but the foilage at length glabrate; leaves spatulate or the upper lanceolate; head sparingly leafybracted or naked at base; involucre naked, its bracts ovate-lanceolate ad somewhat rigidly cuspidate acuminate, whitish with green center, 1-2 in. or more high; rays showy, 1-2 in. long, bright blue or violet; akene boardly ovate, almost cartilaginous, glabrate, with a few glochidiate hairs; pappus of 2 subulate stout awns shorter than the akene, and a circle of rigid scales. "Sandia Mts., four miles south of Tieras." 1908.

T. SERICEA, Hook. Depressed acaulescent, with closely sessile solitary or few heads, tight against the ground, 1-3 to 3-4 in. long, surrounded by the linear or spatulate leaves, an inch or two high; plants sericeouspubescent; involucral bracts narrowly lancedate, acute; rays white or purplish; hairs on the achene glochidiate. In the red soil around Tijeras in the Pinon Soc. Mar. 14, 1908. A strikinkly beautiful blossom in early spring.

T. strigosa; Nutt. Mesa Townsendia.

Flowered when only 1-2 in. high, often attaining 6 to 7 in. in hight; often 1-flowered, early leaves spatulate later ones linear; bracts of involucre broadly lanceolate, acutish, in about two ranks, the outer shorter. Common on the Mesa in spring. April 19, 1908.

14. BACCHARIS, $L$. (Grounded-tree.)

Commonly smooth and resinous shrubs, flowers whitish or yellow, imbricated involucre, corolla of the pistillate flowers very slender and thread-like, of the stamenate larger and 5 lobed, achenes ribbed.

B. WRIGHTII, Gray. Diffusely branching, sparsely leaved; slender branches terminated by solitary heads; leaves linear; 1-nerved, small, the upper mostly linearsubulate; involucre 1-3 to 1-2 in. high; pappus fulvous or sometimes purplish.

15. ANTENNARIA, Gaertn. (Everlasting.)

Perrennial white woody herbs, with entire leaves, corymbed heads of yellowish flowers; dry and papery whitish involucral bracts. imbricated; convex or naked 


\section{WATSON-Plants of Bernalillo County.}

receptacle, pappus united at base so as to fall in a ring.

a. Plantaginfolia, Hooks, (Plantain-Leaved E.)

Spreading. by offsets and runners, low three in. to a foot or more high; leaves silky-woolly when young, at length green above and hoary beneath; those of the unbranched stem small, lanceolate, the radical obovate or oval-spatulate, petioled, large, three-nerved. Common in the monutains under the "Yellow Pine."

\section{MELAMPODIUM.}

Branching herbs with opposite, mostly sessile' leaves; pedunculate heads terminating the branches or in the forks, short or conspicuous, fertile rays, perfect but sterile disk-flowers, convex or conical chaffy receptacle.

M. CINEREUM, D. C. Cinerous or even silvery-canescent or greener; leaves linear or lower lanceolate or spatulate, entire or undulate or even sinuate-pinnatifid; rays 5 to 9 , cuneate-oblong, 2 or 3 -lobed at apex, white. Particularly common on the hills of "Terrace Mesa."

17. Berlandmera, D. C. "Arroyo Ox-Eye."

Alternate leaved perennials with pedunculate head, the 5 to 12 fertile flowers in a single series. Involucial bracts in about 3 series, the inner dilated and exceeding the disk, the outer smaller and foliaceous.

B. IYrata; Benth. Stems mostly: low, and heads with long peduncles; canescent with minute white or gray tomentum; leaves all alternate at base, pinnatifid, at length greenish above; achenes obovate. Common in the arroyos on "Terrace Mesa and elsewhere."

18. PARTHENIUM, $L$.

Ours shrubs with alternate leaves, small corymbed inconspicuously radiate heads of whitish flowers, hemispehical involucie of 2 ranks of short-ovate or roundish scales, conical, chaffy receptacle, and obcompressed achenes.

P. INCANOM, $H B K, 1$ to 3 feet high; much branched, canescent with fine tomentum, leaves mostly obovate in outline; sinuately pinnatifid into 3 to 7 oblong or roundish and obtuse lobes; heads numerous, longer than broad; pappus a pair of short-subulate ercet or at length spreading awns.

19. AMBROSIA; Ragweed.

Coarse homely weeds, with opposite or alternate,

\section{Bulletin University of New Mexico-No. 49}

lobed or dissected leaves; inconspicuous greenish flowers; fertile heads 1-3 together and sessile in the axil of leaves or bracts at the base of racemes or spikes of sterile heads, 1-flower in each head consisting of pistil only.

Leaves opposite, large, palmately cleft only, - - - - - A. APTERA.

Many leaves alternate, all once or twice pinnatifid, - - A. ARTEMESIAEFOLIA. A aptera, D. C. Western Giant Ragweed. Stem stout, 3-10 feet.high, rough hairy, leaves large, commonly 5-lobed, the middle lobe often 3-cleft; fruit 4-8 monbed and with 4-6 short or obsolete tubercles. Along acequias, along stream bank in Tijeras Canon.

acequias, along stream, $L$. Rag-weed, Hog-weed. Much branched, 1 to 3 feet high, hairy or roughish-pubescent; leaves thin, twice pinatifid, smoothish above, paler or hoary beneath; fruit obovoid or globular, armed with about 6 short acute teeth or spines. A very common weed in fields in the East but rare here.

20. Franseria, Cav. Spiny Rag-weed.

Ours an herb and low, leaves alternate. Head 1flowered in ours.

F. Hooreriana, Nutt. Duffusely spreading, freely branching, hirsute; leaves ovate or roundish, bipinnate or upper oblonb and pinnatifid; fruit 1-4 to 1-3 in. long armed with flat, thin, long, and straight spies. In sandy arroyo north of Menaul School.

21. Xanthium, Tourn, Cockelbur. Clotbur.

Coarse grayish weeds, with low, branching, stout stems; alternate toothed or lobed leaves, petiolate; fertile involucre closed, hard, covered with hooked bristles so as to form a bur, rough and about 1 in. long (in ours) 2-celled and 2 -flowered.

$x$. CANADENSE, Mill. Leaves cordate or ovate, 3nerved, stem often with brown dots. Very common in low ground along the river and acequias. Burs troublesome to animals.

22. . zINNIA, $L$.

Herbaceous or slightly shrubby plants, with opposite and mostly sessile, entire leaves, single and showy heads terminating the branches, disk flowers perfect and fertile, involcuere of closely appressed and imbricated, dry, firm, broad, bracts; chaff of the conical or cylindraceous receptacle folded around the disk 
flowers.

z: GRANDIFLoRA, Nutt. (Large-flowered z.) Roughhairy ; leaves linear and rigid, 3-nerved at base, connate sessile involucre usually 1-3 in. long; ligules 1-2 to 2-3 in. long. Common on the gravelly hills of the Terrace Mesa and also on the bases of the Sandia Mts. A very pretty plant with a pungent odor.

23. LEPACHYS, Rab.

Perrennial herbs with alternate pinnately divided leaves, the stems or branches naked above and bearing single showy heads with yellow or part-colored drooping neutral rays, grayish disk, few, small, spreading involueral bracts; truncate chaff, thickened and bearded at tip and partly embracing the flattened and margined achenes.

L. COLUMNARIS, Torr and Gray var. PULCHERRIMA. Pretty L. Rough hairy, 1 to 2 feet high, branching from the base, terminated by long peduncles bearing a showy head; divisions of the cauline leaves 5-9, from oblong to narrowly linear, sometimes 2 to 3 -cleft. Rays commionly 1 in. long or more, yellow (in the species), but in the variety with part or the whole of the upper surface brown-purple.

\section{4. aymnolamia. $H . B . K$}

Ous herbs with alternate or opposite leaves on the same plant, heads of yellow flowers on peduncles terminating the branches, sterile rays, chaff strongly concave or embracing the compressed achenes.

G. MULTIFLORA, Rothrock. Annual 1 to $3 \mathrm{ft}$. high, hairy; leaves from narrowly linear to lanceolate, entire or obscurely denticulate. On "Rim. Rock" of Sandia Mts., especially south end. Late Summer.

25. HELIANTHUS, $L$. (sUNFLOWER.)

Coarse and stout herbs with solitary or corymbed heads, yellow neutral rays; involucre imbricated, herbaceous or foliaceous; achenes 4 sided, smooth.

Annuals, receptacle flat, leaves alternate

$$
\text { - - - - - - -. - - H. ANNUUS. }
$$

Perennials, receptacle convex, lower leaves usually

$$
\text { opposite - - - : - H. PUMILUs. }
$$

H. ANNUUS. L. (Common S.) Tall and rough, leaves rough or the lower cordate, serrate; involucral bracts broadly ovate to oblong, long-pointed, ciliate; disk an inch broad or more, brownish; abundant in low places in the valley, along the river, acequias, etc.
Also in Tijeras Canon.

PUMILU, Nutt. Hispid and scabrous thruout;

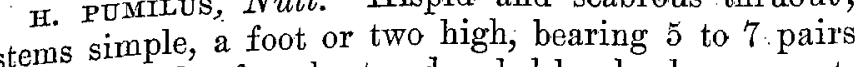
stems simes and a few short peduncled heads ; leaves mostly ovate-lanceolate, acute, entire or nearly so, 1.5 to 4 . in. long, rigid, abruptly contracted at the base into a short margined petiole; involucie less than 1-2 in..high, shorte hirsute, its bracts-imbricated in about 3 series, oblong-lanceolate, acutish; disk yellow. Bear Canon. Sept.

\section{VERBESINA. . (CROWNBEARD.)}

Mostly perennial herbs, with toothed leaves. decurrent on the stem, several to many-flowered heads ; mostly yellow.

v. ENCELIOIDES, Benth and hook: Branching cinerous annual; leaves alternate, ovate or cordate to. deltoid, lanceolate, the petioles mostly winged and auriculate at base; rays numerous and fertile; achenes mostly with short awns. In valley towards Alameda and also in Tijeras Canon.

27. Thelesperma. Less.

Perennial glabious herbs, with opposite, finely dissected leaves; pedunculato many-flowerd heads; achenes nearly terete, wingless, beakless,. pappus of 2 short subulate awns.

T. GRACILE, Gray. Quite rigid, naked above; leaves once or twice 3 to 5 -nately divided or parted into filiform or linear lobes; bracts of the outer involucre 4 to 6 , very short, ovate to oblong; disk mostly yellow, the narrow awns of the conspicuous pappus often nearly as long as the corolla-tube. Common on the Mesa and conspicuous in early summer, especially in the sandy arroyos. . Looks like Hymenopappus flavescens. but smooth.

28. BAILEYA. Harvey and Gray:.

Soft and densely floccose-woolly annuals, with alternate leaves, the lower once or twice pinnatifid; terminal long-pedunculate solitary heads of yellow flowers; disk flowers with glandular bearded teeth.

B. Moltiradiata. 'Harvey and Gray. 25 to 50 ligules 1-2 in. long or less. Clommon in the sandy arroyas of the mesa, mostly in the spring.

$$
\text { 29. ВаніA. Log. }
$$

Ours herbaceous, leaves mostly alternate, small or middle sized heads on a peduncle; flowers yellow, all 


\section{WATSON-Plants of Bernalillo County}

fertile.

B. PEDATA, Gray. Cinereous-puberulent; leaves pedately. divided, commonly into 3 petiolate obovate or cuneate segments, of which the lateral are 2-parted, and the middle 3 to 7 lobed; lobes obovate or broadly oblong; heads 1-2 in. high or less; about 12 oblong rays; 10 to 12 scales of pappus spatulate-oblong with costa vanishing near the obtuse apex. On mesa hills near "Highland Park."

30. HYMENOPAPPUS, $L$ Her.

Biennial herb, dissected leaves, corymbed small, many-flowered heads of whitish or yellow flowers; 6-12, loose, broad involucral bracts, petal-like with greenish-white or yellowish margins.

H. Flavesciens. (Yellow United-papphus.) Densely white tomentose, divisions of leaves dinear; heads 1-3 to 1-2 in. high.

31. POLYPTERIs. Nut. (False Cockle.)

Glandular pubescent herb, undivided and mostly entire leaves, alternate and petioled; rose-purple flowers which at a glance look like those of a Lychnis.

P. Hookeriana: Gray. Somewhat viscid above, leaves lanceolate, inner bracts of involucre with purplish tips; rays 8-10 deeply 3 cleft. On mesa; not abundant.

32. actinelua. Pers Nutt.

Low herbs, leaves narrow, dotted with resinous atoms; solitary, many-flowered heads terminating scapes or slender naked peduncles, wedge ovate or lanceolate, thin or coriaceous nearly equal involucral bracts, appressed in 2 or 3 rows. Pappus of 5 or more ovate very thin chaffy scales.

Involucre or numerous not rigid bracts; leaves entire, - - - - A. ACAOLIS.

Involucre of rigid bracts in two rows, the outer connate at base, leaves 1 to 3 , pinnately $d i$ vided, - - - $\quad-$ a. oDoratre.

A. Acaulis, $\mathrm{Nutt}$, (Stemless Raylet.) Densely caespitose, the branches of the caudex thick and crowded, canescently villous or sericeus; leaves thickish, from spatulate to nearly linear, commonly short, 1-2 to 2 in. long. Densely crowded on the caudex, scape 1-2 to 6 in. high. "Rim Rock" of the Sandia Mountains.

A. ODonata, Gray. "Limonillo." Annual 1 to $2 \mathrm{ft}$.

(18)
Bulletin University of New Mexico-No. 49

high, branching, leafy, somewhat floccose woolly; heads high, branching scattered; lobes of leaves filiform.. Used as a perfume plant. Atrisco. May, 1908.

33. GaILlaRdia, Fong.

Erect hèrbs, with large showy heads of yellow and purplish fragrant flowers on terminal peduncles, cleft or toothed neutral or fertile rays, outer involucral bracts larger and loose and foliaceous; pappus of 5 to 10 thin scales with the excurrent nerve forming an awn.

G. PUlChella. Fong. (Pretty G.) Annual, hairy, $1 \mathrm{ft}$. high or less; leaves from: entire to pinnatifid; lower part of ray red-purple or darker, the upper or teeth yellow, an inch long or less. On the hills of "Terrace Mesa." Quite common. in summer and autumn.

\section{FLAVERIA. Juss.}

Glabrous annual, sessile leaves, yellow flowers, terete and striate achenes.

F. ANGUStifolia. Pers. (Narrow-leaved F.) Erect, leaves linear to lanceolate, serrulate or entire. involucre of mostly 3 bracts, heads in close or dense, leafy, terminal glomerule (head.). Common in low alakline soil in the valley. Summer. Looks like a Bidens or Sticktight at a distance.

\section{DYSODIA. (FETID MARIGOLD.)}

Annual or biennial herbs, glands large and giving a strong odor; large heads of yellow flowers terminating the branches; flat receptacle, not truly chaffy but with short chaff-like bristles; slender 4-angled anchees and pappus a row of chaffy scales dissected into numerous rough bristles.

D. CHRYSANTHEMOIDES. Lay (Chrysanthemum-like.)

Nearly smboth, diffusely branched; leaves opposite, pinnately parted, the narrow lobes bristly-toothed, or cut; rays few and inconspicuous, scarcely exceeding the involucre. Less dry places in the valley, very common in vacant lots in town.

\section{HYMERATHERIUM. Cass.}

Low (ours shrubby), with a penetrating but pleasant odor; terete and striate achenes and pappus of several or numerous scales resolved above into 3 or 5 bristles (in ours).

H. ACERosum. Gray. Low, rigid, exceedingly branched, filiform-aceose (i. e. needle-shaped) leaves; (19) 
usually with axillary bundles of shorter ones; heads 1-4 to 1-2 in. high; pappus simple of 18-20 scales; heads sessile at the ends of woody branches; leaves opposite, entire. Very common on the hills of the mesa. From summer to late autumn. Nov.

37. PECTIS. $L$. LEMON PLANT.

Low, spreading; glabrous, heavy-scented herbs with narrow opposite leaves, and usually with many slender rigid bristles at the base; radiate heads, of yellow flowers; small naked receptacle; and (in ours) pappus of 4 or 5 mostly united scales and sometimes 1 or 2 slender short awns.

P. ANGUSTIFolia. Torr, A pretty low plant with abundant flowers, with a strong scent very much like that of lemons. Common on the base of the Sandia Mts., especially at the mouth of Tijeras Canon.

38. aCHILlea. Vaill. YARROW.

Perennial herbs with small corymbose many-flowered radiate heads few and fertile rays; oblong, flattened, margined achenes and no pappus.

A. Millefolidum. $L$ : (Common' Y.) Stem simple; leaves twice-pinnately parted, the divisions linear, 3 to 5 cleft; crowded corymb, compound, flat topped; rays $4-5$ short and white, sometimes a pale rose-color. A European weed introduced thruout North America but rare here. It grew around the trees on East Silver Ave.; Terrace Addition in 1908. A heavy 'scented plant. Also called Milfoil.

A. LANosa. Very similar but smaller and with a smaller corymb. Quite common on the tops of the Sandia Mts."among the shrub oaks. "Western Yarrow."

38. ARTEMESIA. $L$.' 'SAGE-BRUSH. WORMWOOD.

Bitter and aromatic herb or shrubs with small, nodding, heads. in panicled spikes or racemes; small, flat receptacle, obovoid achenes. with a small summit, ours are perennials, 1 - to. 5 ft: high.

a. Iudoviciana, Nutt. Whitêned woolly thruout; leaves lanceolate, the upper mostly entire, the lower usually cut-lobed, toothed or pinnatifid, the upper surface sometimes glabrous and "green;' heads mostly sessile in narrow panicles. Quite common in the mowntains and on the mesa.

A. MEXICANA. Willed. Less woolly tomentose, and glabrate; leaves narrow lanceolate to linear some 3 .

(20) to 5 cleft or parted, the radical cuneate. incisely pinnatfid or trifid; heads very'numerous in an ample loose panicle.

40. SENECIO. Tourn. GROUNDSEL, or BUTTER-WEED.).

Herbs or shrubby, with alternate leaves, solitary or corymbed, many-flowered heads of chiefly yellow flowers; naked receptacle and pappus of very soft, numerous slender bristles:

Heads an inch high or nearly, rayless, nodding, s. BIGELOVII

Heads 1-2 in. or less high; erect, rays present, Stems few leaved or upper cmall; leaves not linear, - - - - s. FENDLERI. Stems leáfy, leavés or divisions linear,

s. DOUgLasir.

s. BIGELOVIA, Gray (Rayless G:)Robust, 2 to $3 \mathrm{ft}$. high, leafy up to near the raceform or simple paniculate inflorescence, a few scattered hairs only when young; leaves from elongated-oblong to lanceolate, dentriculate or dentate, acute or acuminate; rádical and lower cauline 3-6 inches long abrupt at base and naked-petioled, or tapering into a winged petiole or partly clasping base; upper lanceolate: Sandia Mts.

S. FENDLERI, Gray. (Mountain R.) Very woolly, smooth when old; stems rather stout; 5-15 in. tall, leafy, the larger plants branching; leaves lanceolate, serrate to pinnatifid, radical sometimes almost entire; achenes glabrous. 'Bear Canon.

..s. Douglasir. D. C. (Shrubby B.) Usually decidedlyshrubby at base, more commonly parted into. 3-7 linear divisions; heads 1-3 to 1-2 in: high; rays 8-18. achenes finely conescent. Very common on the mesa. 41. cuicus. Tourn: Thistles.

Mostly biennial herbs, usually with large terminal heads of reddish-purple or lighter flowers.

c. ochrocentrous. Gray. Often tall 1 to. $8 \mathrm{ft}$. leaves commonly but not always deeply pinnatifid and armed with long yellowish prickles; heads 1 to 2 in. high; involucral bracts rather broad and flat; the viscid line on the back narrow or not rarely obsolete, tipped with a prominent spreading yellow bristle; corolla purple, rarely white. Common at the base of the mountains and on the adjoining mesa and spreading down the arroyas. Occasionally on the open mesa.

c. undolatus. Gray. 'Usually lower 1-3 ft. high; (21) 


\section{WATSON-Plants of Bernalillo County:}

leaves rarely pinnately parted, moderately prickly; heads mostly 1 1-2 in. high; principal involucral bracts mostly thickend on the back by the broader glanularviscid ridge, smaller and narrower and tipped with an evident spreading short prickle; corrola rose-color, purple or white. Tops of the Sandia Mountains.

42. STEPHANOMERIA. Nut.

Mostly smooth and glabrous perennials with branching and rigid or rush-like stems, small and scale-like leaves, heads of 3-20 flowers, cylindrical or oblong involucre of several appressed and equal flat membranaceous bracts and some short calyculate ones.

s. RUNCINATA. Nutt. A comparitively stout and rigid perennial, branching from thick roots; heads 1-3 in. high or more and scattered along the branches. Some runinate-pinnatifid leaves below. Somewhat common on the mesa and blossoming from spring to Nov.

43. HIERACIUM. Tourn. HAWKWOOD.

Hispid or hirsute perennials; 12 to many-flowered heads; naked receptacle.

H. FENDLERI. Schultz. Subscapose, not rarely $1 \mathrm{or}^{*}$ 2 leaves towards base of simple or branching stem; sparsely rough hairy; radical leaves spatulate or broader, cauline lanceolate; achenes tapering from near the. base to summit; pappus sordid whitish. In the Mountains.

44. TARAXACUM. Haller. DaNDELION.

Perennials or biennials, with radical runcinate leaves; many flowered large heads of yellow flowers, solitary on a slender, hollow scape.

т. officinate. Weber. The common dandelion of the East, an intruduction from Europe. Quite rare here. There are a few on lawns and gardens in town.

45. PYRRHOPAPPUS. A. $C$. FALSE DANDELION.

Annual or biennial herbs, with solitary heads of deep yellow flowers terminating the branches. Ours more or less leafy-stemmed and branching.

P. CARouinianis. D. C. 18 inches to 3 feet high, leaves oblong or lanceolate, entire, cut, or pinnatifid, those of the stem partly clasping; fruiting heads an inch or more high; calyculate involucral bracts loose, 1-2 to 1-3 the length of the inner set. Along the Rio Grande and in yards. Apparently introduced.

4. sonchus. $L$. sow-thistLe.

(22)
Bulletin University of New Mexico-No. 49

Leafy-stemmed, chiefly smooth and glaucous; coarse weeds, with many-flowered heads in a corymb or umbel.

s. ASPER. Vill. (Rough S.) Stem leaves lobed and spiny toothed, the auricles of the clasping base roundd, achenes margined, 3-nerved on each side, smooth. 1 European weed occasional around the gardens and A European weed the town and val.

yar CAMPANULACIEAE. (BELL FLOWER FAMILY).

2. CA:MLPAN with alternate leaves, scattered, generally

Herbs whow, flowers; regular 5-lobed bell shaped blue and sholla; single style, 2 or more stigmas, and 2 to rotateral-celled many seeded pod.

Calyx 3 to 5-lobed; corolla rotate, flowers dimorphous and auxilliary: (1). SPECULARIA.

Calyx ö-cleft, corolla bell-shaped; flowers all aliket terminal or axillary', - (2) CAMPANULA. 1. SPECULARIa. Heister. (Venus Looking-glass).

1. SP annuals, with blue or purplish flowers, the earlier cleistogamous; stamens with membranaccous hairy filiaments, shorter than the anthers, 2 to 4 stigmas and a prismatic or elongated-oblong pod which is 2 to 4 celled and opens by small lateral valves.

s. Perfoliata. A. D. C. Stem very leafy thruout, hirsute or hispid on the angles; leaves round-cordate and clasping, mostly crenate, veiny; flowers sessile. Sandia Mts.

\section{Campandia. Tourn. BeLl-FLOWER.}

Herbs with terminal or auxillary, usually blue, flowers, 5 separate stamens with filaments broad and membranaceous at base; 3 stigmas and as many cells of the ovary, and a short pod opening on the side by as many valves or holes.

c. PETTOLATA. Slender, root leaves round, cordate, or ovate, early withering away, stem linear. Sandia Mts. Quite common on the Rim-Rock.

3. CUCURBITACEAE. (GOURD FAMILY.)

Mostly succulent herbs with tendrils, alternate palmately-lobed or veined leaves, monoecious or dioecious flowers, calyx tube cohering with the 1 to 3 -celled ovary. A large tropical family including our cultivated squashes, cucumbers, pumpkins and melons. CUCURBIta. $L$. CALABACILLA.

Prostate seabrous vines, with large yellow flowers, monoecious and mostly solitary; calyx companulate (23, 
and also the corolla which is 5:lobed to the middle, filaments of the stames distinct, 3 to 5 stigmas each 2-lobed, fruit smooth and fleshy with a hard rind.

c. Foetmissima. $H . B . K$. (C. Perennis gray) Root very large; leaves thick, triangular-cordate, rough and whitish; flowers 3 to 4 in. long; fruit globose or obovate, 2-3 in. in diameter. "colar. and size of . an orange when ripe." Sparingly along the arroyos of the mesa, more abundant along the stream in Tijeras Canon and along the acequias of the valley.

4. VALERIANEAE. (VALERIAN FAMILY.)

Herbs with opposite leaves and no stipules; flowers in panicled or clustered cymes; coherent calyx-tube; tubular or funnel form, often irregular, mostly 5-lobed: corolla. Slender style, 1-3 stigmas.

$$
\text { vaLARIANA. Tourn. }
$$

Calyx-limb of 5-15 setiform lobes, which are inrolled and inconspicuous until frùiting. Stamens 3, roots of peculiar scent. Flowers white or rose-colored.

v: ovata. Rydb. Leaves oval or upper lanceolate, usually with a small lobe at the base, 1 to 2 in. long. A'miong the rocks high up in the Aspen Soc. of the Sandia Mountains.

5. GAPRIFOLIACEAE. (HONEYSUCKLE FAMILY.)

Shrubs with calyx tube coherent with the 2-5 celled ovary, fruit a 1 -seeded or more ( 2 in ours) berry. In ours the corolla is tubular.

SYMPHORICARPOS. Dill. (sNOWBERRY.)

Low and branching upright shrubs with small shortpetioled leaves which are downy underneath and entire or 'wavy toothed or lobed on young shoots; white or rosy-tinted flowers in axilarry clusters (in ours) short persistent calyx-teeth, bell-shaped regularly 4 or 5-lobed corolla, a 4-celled ovary but only two of the cells with a fertile ovule.

s. ROTUNDIFolius. Gray. Tomentulose, to glabrate leaves orbicular to oblong-elliptical, thickish, 1-2 to 3-4 inches long, corolla elongate campanulate, 1-4 to 1-3 in. long, its tube pubescent within, below the stamens, and 2 to 3 times the length of the broad and short lobes. Very common on Rim Rock where it is often the predominant plant and quite common lower down. Fruit white.

6. RUBIACEAE. (MADDER FAMILY.)

Ours are herbs, ovary 2-4 celled.
Orules numerous in each cell: Leaves opposite, 1. HOUSTONIA: Ovules solitary, leaves in whorls without stipules,

1. Houstonia. $L$. BLUETs.
Low herbs, dimorphous flowers, funnel form, ' 4

2: 'GATIUM. lobed corolla, 4 sțamens.

H. HUMIfusa, Gray. Aninual, much branched from the root, forming a dense low tuft, pubescent and viscid, leaves linear-laceolate, thickish 1-2 inch or more long with setulose-ciliate scarious stipules; flowers in all the forks, (crowded) with the leaves at the ends of the branchlets; calyx 4 parted into long lobes; corolla pale purple or nearly white, 1 inch long. Quite common on the mesa in the spring and early summer.

2. GaLIUM. $L$. BEDSTRAW, CleATERS.

Slender herbs with square stems, small flowers and obsolete calyx-teeth, 4-parted rọtate corolla, 4 (rarely 3) short stamens, 2 styles, dry globular twin fruit separating .when ripe into two seed-like indehiscent 1 -seeded carpels. Ours are wholly herbaceous, margin and midrib of leaves and angles of the stem rough. They occur only. in the Sandia Mts. in mesephytic societies.

Fruit beset with hooked bristles; leaves, 6. in a whorl, - - . - . - G. TRIFLORUM.

Fruit without bristles; leaves 4 in a whorl,

$$
\text { - - - - - - - -G. BOREALE. }
$$

G. TRIFLoRdM, Mitcx. (Three-flowered B.)

Diffusely procumbent, smoothish; herbage sweetscented in drying, stems 1 to 3 feet long; leaves lanceolate or narrowly oblong ( 1 to 2 in. $\log$ ); cymes once or twice 3-rayed; pedicels soon divaricate; corolla yellowish-white to greenish.

G. BoReale, $L$. (Northern B.) Erect, 1 to $2 \mathrm{ft}$. high, mostly smooth and glabrous, very leafy, leaves linear to broadly lanceolate, 3-nerved blunt; often in the fascicles of smaller ones in the axiles; flowers veryinum; erous in a terminal panicle, fruit small hispid orst ffrrsts" canescent and soon glabrous and smoothy,

7. PLANTAGINEAE. (PLANTAIN FAMILX)

Chiefly stemless herbs, with regular ${ }^{4}$-merous, spiked flowers, stamens inserted on the tubesof the dry and membranaceous veinless corolla and alternate with its lobes.
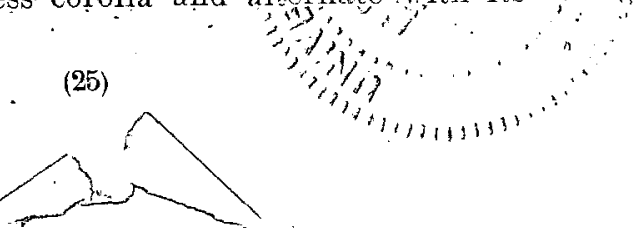


\section{WATSON-Plants of Bernalillo County}

PtaNTAgo, Tourn, PlaNtain RIBWORT.

Annuals' or perennials with ribbed leaves, small whitish flowers in a bracted spike on a naked scape. Calyx of 4 persistent scarious-edged sepals; corolla withering on the 2-celled pod; 4 stamens.

Leaves oval introduced weed, - P. LANCEOLATE.

Learis lanceolate or lance-oblong,P. IANCEOT.iTE.

Leaves oblorg linear to filiform, native

- - $\quad$ - $\quad$ - P. PATAgonia. P. major, $L$. Clommon P. (in the East.) Smooth or rather hairy, leaves often toothed abruptly narrowed into' a channeled petiole; spike dense, obtuse, seed's angled, reticulated. Occasionally about gardens and yards. Not common here.

P. Lanceolata. L. English Plantain. Mastly hairy, scape grooved-angled, at length much longer than the leaves, slender, 9-24 in. high; bracts and sepals dry an dbrownish, seeds hollowed on the face. Rarely occurs on lawns in town, doubtless introduced with the grass seed. Very common in the East.

P. PATAGoNica. Jacq. var. GNAPHarioI DEs. Gray.

White with silky wool; leaves 1-3 nerved, varying from oblong-linear to filiform; spike very dense; 1-4 to 1-2 in. long, wooly. Low, usually less than six in.' high. Very common on the mesa in spring.

8. VERBENACEAE. (VERVAIN FAMILY.)

Herbs or shrubs with opposite leaves, more or less 2-lipped or irregular corolla, 4 didynamious stamens, 2-4 celled-fruit, dry or drupaceous and usually splitting when ripe into as many 1 -seeded indihiscent nutlets. Differs from Labiatae in the ovary not being 4 lobed, the style therefore terminal.

VERBENA Tourn VERVAIN.

Herbs, with bracted flowers, sessile in a single or often panicled spikes, tubular, 5-toothed calyx; tubular (of ten curved) salverform corolla, with somewhat unequa'lly' 5. cleft border; 4 perfect and included stamens, " "upper paipoccasionally without anthers.

$\therefore("$ "Floners smazl, in narrow spikes.

Widely spreading or procumbent-hairy

- - - - - - - - - v. BRACTEOSA.

More erect; hairs scattered - - v. RUNDIs. Floẅers showi, spikes shorter or capitate.

Gland of ianthers small, short, sometimes incon-

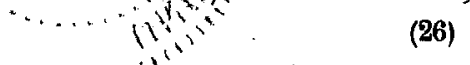

Bulletin, University of New Mexico-No. 49

spicuous, on the middle, of the back,

- - - V. BIPINNATIFIDA.

Gland of anthers oval, as high, and almost as large as one of the cells, - - = v. WRIGHTII จ. BRACTEOsa. $M x$. Leáves wedge-lanceolate, cut-pinv. BRACTEOAd or 3-cleft, short petioled; spikes single, remately flowered, - bracts large the lower pinnatifid. motem in places on, the mesa and on the campus:

Common in preen. Bracts smaller. Bear Canon in Sandia Mts.

V. Bipinnatifida. Nutt. (Mt. Verbena). Roughhairy, 6-12 in. high; leaves $11-2$ to 4 in. long, bipinnately parted or 3 parted into mbre or less bipinnatifid divisions, the lobes commonly linear or broader; spikes elongated in age; bracts mostly surpassing the calyx; limb of bluish or lilac corolla 1-3 to 1-2 in. broad. Very common among the rocks at the base of the mountains, and ocosionally on the adjoiningmesa.

v. WRIGHTII. Gray. Stem simple below, $2 \mathrm{ft}$. high hispid-pubescent, leaves pinnately 3-7 parted or deeply cleft, contracted at the base into a margined petiole, with lobes mostly lanceolate and acute; corolla light purple, fruiting spike dense and oblong. With the last.

\section{LABIATAE. (MINT FAMIIY.)}

Chiefly herbs, with square stems, opposite, aromatic leaves; more or less 2-liped corolla; didynamous or diandrous stamens; and a deeply 4-lobed ovary which forms in fruit 4 seed-like nutlets orachenes surrounding the base of the single style in the bottom of the persistent calyx.

Anther bearing stamens 2, anthers 2-celled,

Stamens 2; anthers apparently or really 1-celled, Calyx 2-lipped - $\quad$ - $\quad$ - - SAIVIA. Calyx tubular and elongated, equally. 5 , toothed, - '- Stamens 4, upper pair longer than outer,
Divergent, exserted, upper pair declined,

All ascending, not exserted, - CEDRONELIA. hedeoma. Pers. Mock PENNYRoyal.

Mostly odorous annuals or perennials with small leaves; loose auxillary clusters of flowers often forming terminal leafy racemes; ovoid or tubular:13-nerved 
2-lipped calyx, gibbons on lower side near the base and bearded in the throat; 2-lipped corolla, and 2 fertile stamens, the upper pair being reduced to sterile filaments or wanting.

II. DRUmumond, Benth. (Drummond's H.) Pubescent, leaves oblong or linear, obtuse, subsessile, thickish, upper rather shorter than the few flowers in their axils; calyx teeth subulate, the lower nearly twice the length of the upper. Corolla 1-4 to-1-3 in. long and little exerted, to 1-2 in. long and twice the length of the calyx. Sandia Mits.

\section{SALVIA, $L$. SAGE.}

Flowers large and showy; in spiked or racemed or panicled. whorls; deeply 2-lipped ringent corolla, upper lip straight or scyth-shaped, entire or barely notched; lower spreading or pendant, 3-lobed, with middle lobe largest. Ours herbs.

\section{S. Subircisa, Benth}

Pubescent above; leaves oblong-lanceolate, incisely dentate; the floral minute; ovate; calyx glandular, pilose; corolla 1-2 in. long, blue or purplish; rarely white. Along ácequias. Common.

\section{MONARDA, $L$. HORSE-MINT.}

Odorous erect herbs with entire or toothed leaves; rather large flowers in a few whorled heads closely surrounded by bracts; calyx 15-nerved, hairy in the throat; elongated 2-lipped corolla, lips linear or oblong somewhat equal, upper erect, entire or slightly notched. Lower spreading, 3-lobed át apex; middle lobe narrowest and slightly notched.

m.! Fistulosa. "Wild Bergamot." Simoothish or downy, 2-5 ft. high; leaves ovate-lanceolate, the upper and outer bracts whitish or purplish; calyx very hairy in the throat; corolla 1 in. long or more, purple or purplish-dotted. Stamens and style exserted; head terminal and usually solitary. Bear Canon, not common. Also called "Bee-balm." Much visited by bees and butterflies.

Var medis, Gray. Corolla -deep purple. Bear Canon.

\section{LOPHANTHUS, Benth. (Giant Hissop.)}

Tall perennial herbs with petioled, serrate leaves, small flowers, crowded in interrupted terminal spikes, tubulard bell shaped, 15-nerved, oblique, $\cdots 5$-toothed calyx; 2-lipped corolla.
URTICIFolids, Benth. Leaves green both sides, mostly crenate and more or less cordate, sweet-aroInstic; caly $\dot{x}$-teeth lanceolate, subulate-acuminate; corolla light violet or purplish. Sandia Mts. JulyAugust.

CEDRONELLA, Moench.

Sweet-scented perennials, 'with pale purplish flowerse, rather obliquely, toothed, many-nerved calyx; stender 2-lipped corolla, upper lip flatish or concave, 2-lobed, lower 3-cleft, spreading, middle lobe largest.

c. PALLIDA, Lind́l. Green and mostly glabrous; leaves broadly cordate-ovate or subcordate, mostly obtuse, crenate, slender-petioled; infloresence compact; corolla dull rose color. 1-2 in. or more long, very little exserted from the small calyx. Bear Canon. August-September.

10. BORAGINEAE. (Borage Family.)

Chiefly rough-hardy herbs, flowers mostly imitating a one sided spike or raceme; 5-parted calyx; regular 5-lobed corolla; 5 stamens inserted on its tube; a single, style.

Ovary undivided but $2-4$ lobed

(1) HELIOTROPIUM. Ovary deeply 4 parted style rising from he center.

Nutlets armed on back with barbed Prickles.

- - - - - - - (2) ECHINOSPERMUM.

Nutlets not armed, attached more or less laterally.

Corolla white and small - (3) KRYNITZKIA.

Coroila blue or pirple, long, - (4) Mertensia.

Nutlets not armed, altached by the base, flowers yet-

$$
\text { low }
$$
LITHOSPERMUM.

\section{HELIOTROPIUM, Toum. Helitrope.}

Ours herbs, with entire leaves, salverform or funnelform unappendaged corolla, short style with conical or capitate stiguia.

H. CONvolvolaCeUM, Gray.: Morning Glory.

Low, very rough-hairy; much branched; lanceolate, ovate or linear, short petioles leaves; flowers opposite the leaves, and terminal, corolla $1-2$ in: broad, the hairy tube about twice as long as the linear sepals, white. Sandy fields near Isleta. A pretty sweetscented plant.

8. ECHINOSPERMUM, Lehm. STICKSEED. - HEDGE HOG SEED.

Rough-hairy and grayish herbs with small blue to whitish flowers in racemes or spikes, short salver- 
WATSON-Plants of Bernalillo County

form corolla with throat closed by 5 short scales; in cluded stamens and triangular or compressed erect nutlets:

\section{ז. REDowsku, Lehem.}

1 to $2 \mathrm{ft}$. high; leaves linear, lanceolate, or the lower spatulate; racemes leafy-bracteate; calyx becoming foliaceous; nutlets irregularly and minutely sharptubeculate, the marnins armed with a single row of stout flattened prickles sometimes confluent at base - Var copulatum, Gray; with prickles of the nutlet broadened and thickened below and nnited into a wing or border which often, hardens and enlaices, forming a cup. Bear Canon. May-June.

3. KRYNITZKIA. Fisch and Meyer.

Hairy annuals, 5-parted or deeply-cleft calyx, short corolla with more or less fornicate throat.

* Nutlets attached by ventral angle or groove from the base up to 1-3 or 1-2 or the whole length to the elevated thickened base of style.

H. Crassisepala, Gray, leaves ob-lanceolate and linear-spatulate; flower short-piedicled; at least some bracteate; calyx-lobes greatly thickened below in fruit. 3 of the 4 nutlets muricate the other larger and nearly smooth.

**Nutlets acutely triangular, wingless, attached, for most of their length to a subulate gumnobase (that is thickened base of the style.)

к. JAMESII, Gray, (James K.) Rather stout, branched from a woody base, silky, rough-hairy in age; leaves oblanceolate or the upper linear; corolla with prominent crests at throat; fruiting calyx neatly closing over the depressed-globular fruit, nutlets very smooth and shining, almost exact quarters of a sphere. Mesa. April and May.

4. MERTENSIA; Roth. (LUNGworT. BLUE-BELL.)

Ours nearly smooth, leaves oblong- or spetulate lanceolate, rather thick, the lowest petioled; the corolla has the conspicuously '5-lobed limb with small crests in the throat.

M. OBLoNGifolia, D. C. (Oblong-leaved B.)

$A$ span or so high; flowers in a somewhat close cluster tube of the corolla twice or thrice the length

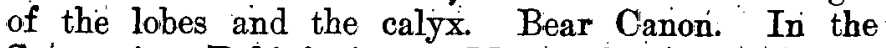
Spruce-Acer-Robinia-Assn. May and Jüne.

(30)
Bulletin University of New Mexico-No. 49

5. LITHOSPERMUM. Tourn. (Stony seed.)

Growmwell, , Puccoon.

Herbs with reddish roots, sessile leaves and axillary or subaxillary or le afy bracted-flowers; stamens with or subaxill filaments and nutlets. white, smooth and polished; with showy flowers.

polishlla light yellow - . - . L. MULTrFLORUM. Corolla bright yellow, crests conspicuous, arching

- - L. ANGUSTIFOLIUM. Corolla orange-yellow, crests in the throat little if at all projecting or arching - L. CANESCENT.

L. Multiflorum, Torr. Many-flowered P.

Minutely rough-hairy, stems wand-like, 1-2 ft. high; leaves linear or lanceolate; flowers numerous, shortpedicelled, the later floral ones reduced to bracts not surpassing the calyx; corolla narrow $1-2$ in. long or surpassing the caly very short rounded lobes and tube fully twice the length of the calyx, crests or folds in the throat inconspicuous. Bear Canon. July, '08.

I AUgustifolium, $M x$. (Narrow Leaved P.) Erect or diffusely branched from the base, 6-15 in. high, minutely rough-hairy and somewhat cinerous, leaves all linear; flowers of 2 kinds, the earlier with corolla 1 in: or less in length and 2 to 4 times the length of the in: or the latter ones and those of the diffusely branching plants with inconspicuous small and pale corolla, without crests in the throat. Quite common on the mesa and in the Mts.

L. Canescens, Lehm, (Downy P.) More or less canescent when young, stem hairy. 6-15 in. high; leaves oblong-linear or the upper ovate-oblong, mostly obtuse, softly silky-canescent, greener with age and floral leaves or foliaceous bracts, large and much surpassing the calyx; corolla 1-2 to twice longer than the calyx. Common east of Tijeras. May, '08.

11. HYDROPHYLLACEAE. Water-leafed Family.

Commonly hairy herbs, with mostly alternate leaves, regular 5 merous flowers. Ovary 1-celled with 2 or 4 parietal placentae which by growing inward may make the pod 2-celled.

Ovary and pod 1-celled; style: 2 cleft; leaves lobed - : - - - - - - PHACELIA. Ovary and pod 2-celled, styles 2, leaves entire NAMA. PHACELIA, 'Juss.

Ours annual or biennial, handsome blue, purple or (31) 
white flowers, in acorpioid raceme-like cymes; 5 parted calyx with naked sinuses; often bell-shaped 5-lobed corolla; slender, often exserted, stamens; and ovary with 2 narrow linear parietal placental usually projecting inward in fruit and forming an imperfect partition in the ovoid, four to many-seeded pod.

P. NEO-MEXicaNa, Thuidber. Viscid pubescent and glandular, and a ft. high or less. Lobes of the corolla: either slightly or conspicuously erose-denticulate: Mesa. Common in spring.

\section{NAMA, $L$}

Chiefly low herbs with funnel-form or sometimes salver-form corolla, purple bluish or white; filiform filaments and styles; stamens commonly of unequal lengths and often unequally inserted; styles 2, mostly distinct.

N. HIsPIDUM, Gray, Hairy Nana. Hispid or hirsute, repeatedly forked; leaves broadly or narrowly linear-spatulate, most of the cauline ones sessile but not at all clasping; flowers lateral and solitary, or 3.5 in terminal unilateral clusters; sepals narrowly linear, very little if at all broadened upward; corolla narrowfunnelform, mostly much longer than the calyx. Pod narrowly oblong, 30-40 seeded. Seeds smooth. Quite common on the mesa. Spring.

12. BIGNONIACEAE, (Bignonia Family.)

Woody plants. Clalyx 2-lipped, 5-cleft; showy, tubular or bell-shaed, five-lobed, somewhat irregular or 2-lipped corolla; stamens inserted on the corolla, 5 cr posterior one and sometimes shorter pair also sterile or madamentry; fruit a large dry pod with flat winged seeds.

Pod flat, leaves compound, - _ (1) TEUCOMA.

Pod terete, fertile stamens only 2 , trees, leaves simple ovate opposite CATALPA.

Pod terete, stamens 4 shrub simple, alternate, linean leaves - - - - - - CHILOPSIS.

TECOMA, Jus. (TRUMPET-FLOWER OR TRUMPET-CREEPER.)

Calyx-bell-shaped, 5-toothed, '4 stamens.' These are well known plants, there are two species neither of which grows wild here as far as I know but T. radicans, is a climbing woody vine with 9 leaflets, and an orange or scarlet corolla, commonly planted as an or- nament. T. stans is an erect shrub with 5 to 11 leaflets and yellow corolla.

CATALPA, Scop. (INDIAN BEAN.)

Tree with large leaves, commonly planted and too frll known to need description.' None grow wild here well known to nerDes is commonly planted. The corolla is thickly spotted, 1 and 1-2 in. long. c. SPECIOSA may is thickly spotted here.' It is a larger tree with white also be conspicuously spotted corolla 2 in. long.

CHILOPSIS, Don. (Desert-Willow Mimbres.)

Shrubs (with us) perhaps 12 feet high with white or purplish flowers in June.

c. Saligna, Don. Pubescent when young, soon glabrous, leaves 4 to 6 in. long and looking as does the bark rous, leaves some willows; hence the name; but the long curved pods are a distinguished mark, lower leaves often opposite or verticillate; corolla 1 to 2 in. long. Along the larger arroyos on both sides of the valley.

\section{PEDALINEAE.}

Herbs, with chiefly opposite simple leaves, and flowers of the preceding orders except that the ovary is 1-celled and the fruit fleshy.

MARTYNIA, L. (UNICORN-PLANT.)

Low, branching, clammy-pubescent annuals with thickish stems, simple rounded leaves, large racemed flowers, 5-cleft mostly unequal calyx; gibbous, bellshaped, 5-lobed and somewhat 2-lipped corolla, 2 to 4 fertile stamens; fruit terminated by a beak which splits into 2 hooked horns.

M. FRAGRALLs, Lindl. ("Toloache.") Leaves from round to oblong-cordate, somewhat lobed and sinnatedentate, 3 to 5 in. broad; corolla 1 to 2 in. long and wide, sweet-scented, from reddish to violet-purple. Quite common in Tijearas Canon and occasional in arroyos of the mesa.

14. OROBANCHACEAE. (Brown-rape Family.)

Low, thick, and fleshy herbs, root parasites, and bearing scales in place of leaves, seeds minute.

APHYLLON, Mitch. : (Naked B.)

Brownish or whitish, purplish or yellowish flowers, glandular-pubescent as are also the scapes; corolla somewhat 2-lipped; included stamens, and pod with 4 placentae.

A. FASCICULATUM, Gray. Stem often emergent and mostly as long as the numerous fascicled peduncles

(33) 
which arise from the axils of fleshy loose scales and are not bracteolate; corolla dull-yellow or purplish, only obscurely bilabiate. Sandia Mts.

A. MULTIFLORUM, Gray. A span or two high, flowers nearly sessile, calyx, with two bracts, corolla an inch or more long, purplish. M ountains and mesa. Quite common.

15. SCROPHULARINEAE. Figwort Fam.

Ours herbs with didynamous stamens, or perfect stamens often only2 (rarely 5), inserted on the tube of the 2-lipped or more or less irregular corolla whose lobes are imbricated in the bud.

I. Upper lip or lobes of the corolla covering the lower in the bud, pod usually septicidal.

Corolla tubular with spur or sac at base below,

Corolla tubular not spurred or saccate

(1) maUrandia.

Flowers clustered or cymed, stame

ilont of a 5 th, - - (2) PENTSTEMON

Flowers solitary in axils of bracts of leaves, stamiens 4, no rudiment, - - MIMULus.

II. Under lip or lateral lobes of corolla covering upper commonly loculicidal.

Anther cells unequal or, dissimilar, (4) castrileia. Anther cells equal, parallel and all alike,

\section{MAURANDIA, Ortega.}

Herbs, climbing mostly by the slender tortile petioles, with cordate-triangular or hastate leaves, only the lower opposite; showy purple or rose-colored (rarely white) flowers, nearly funnelform ringent corolla, barely gibbous at base and with 2 longitudinal and commonly bearded intruded lines or plaits instead of palate.

M. WISLIZENI, Engelin. Glabrous, leaves hastate or sagittate; corolla pale blue, sepals becoming very large and veiny. A sandy field towards Isleta. July and August.

9. PENTSTEMON, Mitch. BEARD-TONGUE.

Perennials, with opposite leaves, mostly showy flowers, 2-parted calyx, tubular or more or less inflated or bell-shaped, 2-lipped corolla. The sterile filament usually as long as the others. Ours are all mountain forms except number 6 .

Anthers dehiscent from the base towards; but not to the apex, corolla red,

(1) P. BARBATUS. Dehiscent to the apex but not confluent (2) P. GLABER. Dehiscent confluently thru the apex.

Pubescent thruout or above viscid.. . . . . .

(3) P.CRIstatos.

Leaves from ovate to laceeolate

Lower lip conspicuously bearded within

- - - - (4) P. confertus.

Lower lip sparsely villons-béarded within

(5) P. GLAUUCUS.

Leaves linear lanceolate or narrower, mesa species - - $\quad-$ c. P. AMBiguUs. 1. P. Barbatus, Nutt. (Bearded P.) Táll 2-feet, leaves lanceolate, lowest oblong or ovate corolla strongly 2 -lipped, 1 in. long from light pink to carmine; base of the lower lop or throat usually with long yellow hairs, sterile filament usually glabrous, var Torreyi, Gray-(Red P.) Deep scarlet-red with few or no hairs in the throat. Bear Canon in the Quercus gambelii. Poplar Assn.

2. P. GLaber, Pursh, glaucous or glaucescent or very glabrous, 1 to 2 feet high, leaves oblong-lanceolate, thyrsus elongated and many-flowered, corolla 1 to 1-4 and 1-2 in. long, blue or violet. Bear Canon.

Var cyananthus, Gray. Usually taller; leaves all broad; the cauline ovate or subcordate and ovate-lanceolate; thyrsus dense. Sandia Mts., descending to the Quercus gambelii Soc.

3. P. CRistatus, Nutt. Phubescent, or above viscidvillous, leaves from linear-lanceolate to narrowly oblong; corolla more funnelform, being less abruptly dilated, lower lip long villous wnthin, sterile filament exserted, densely yellow bearded. Higher up on the Sandia Mts. than the preceding especially in Quercus undulata Jamesii Soc.

4. P. Canfertus, Dougl var CAaeruleo-purpureus, Gray. Glabrous thruout or the infloresence and calyx viscid-pubescent or puberulent, from 2 inches to 2 feet tall ! leaves from oblong to linear, usially entire, thyrsus spiciform, interrupted, naked, of $2-5$ ' dense verticillate flower clusters corolla narrow, 1-3 to 1-2 in. long, blue-purple ad white; lower lip conspicuously bearded within. Sadia Mts., with No. 1.

5. P. glaucus, Graham (?) Glabrous up to the inflorescence, more or less glaucous; stems dwarf 'or as-' (35) 
cending, 4-12 in. high; - leaves thickish; oblong lanceolate; thyrsus short and compact, either simple.or compound, villous pubescent and viscid and glandular corolla lilac-violet-purple, less than 1 in. long, swollen above the short tube, gibbous. A form occurs in Bear Canon asnwering closely to this description but the identity is doubtful.

6. P. AMBiguUs, Torr. Arroyo P.) Glabrous, 1-2 feet high, diffuse and often much branched. Peduncles slender, opposite, the upper. 1-flowered;corolla rose-color and flesh color becoming white, the rotately expanded limb oblique but. obscurely bilabiate, lobes orbicular-oval, throat somewhat hairy, sterile filament glabrous.. Sandy places near arroyos especially on the "Terrace Mesa." June and July.

3. MTMULUS, $L$. Monkey-flower.

-Herbs with opposite leaves, prismatic, 5-angled, 5toothed calyx, upper tooth largest.

M. LUTEUs, $L$ : Rather erect, leaves roundish or sub-cordate, several-nerved and veiny, corolla deep yellow .with -brown purple dots or blotches. "Barrel spring" branch of. Bear Canon, also on the voleanic rock west of town.

4. CA.STILLEIA, Mutis. (Painted Cup.)

Herbs with alternate (entire, linear and tomentose in ours) leaves, the floral ones dilated, colored and more showy than the yellow: or purplish -spiked flow: ers, tubular calyx with the corolla tube included, upper lip of corolla long, narrow, arched and keeled, flattened laterally, inclosing the 4 unequal stamens; lower lip short, 3-lobed.

c. INTEGRA, Gray. Leaves 1 and 1-2 to 3 in. long, 1-2 to 1-4 in. wide, bracts red or rose-color; corolla about 1 1-4: in. long. Very abundant on Rim Rock and occasionally in the mountains generally.

5. PEDICULARIS, Tourn. Lousewort.

Leaves -pinnately cleft or dissected, mainly: alternate; flowers in a terminal bracteate spike. In ours the upper lip of the corolla is not strongly arched.

P.' Prócera, 'Gray. Puberulent, steen 1 to 4 feet high, leaves divided into lanceolate or irregularly pinnatifid segments; bracts lanceolate, caudatacuminate, mostly longer than the flowers, serrate or denticulate. or the upper entire; spike 8-15 in. long; calyx lobes much shorter than the túbe; corolla about 1 1-2 in. long, sordid yellowish and greenish-striate. Sandia Mts. towards the top, in shade of spruces and firs. Not very common.

16 SOLONACEAE, NIGHT-SHADE FAMILY.

Herbs or shrubs with alternate leaves, regular 5Heros flowers. and mostly plated corolla, mostly equal stamens inserted on the corolla, single style and Fruit a berry.

Anthers united or coninivent. - (1) SOLANUM Anthers unconnected, mostly shorter than filafilaments.

Corolla rotate-campanulate, or rotate.

Calyx herbaceous and closely covering fruit: - ..- (2) CHAMAESARARACHA. Calyx becoming large and inflated over fruit - . - (3) PHYSALIS.

Corolla funnelform or tubular (4) IYCIUM. Fruit a pod, corolla elongated.

Seeds flattened, large, pod prickly (5) DatTuRA. Seeds not flattened, very small and numerous

1. SOLANUM, Tourn.' Nightshade.

6) NiCotiana:

urs herbs, good-sized leaves often accompanied by a smaller lateral one, mostly lateral and extra-axillary peduncles, 5-parted or cleft calyx and rotate corolla, exserted stamens with very short filaments; and anthers opening at tip by two pores and usually 2 -seeded berry.

Fruit naked, stamens all alike.

Not prickly, annual, flowers white, s. TRIFLoRUM. Prickly, anthers long, corolla violet,

- - - - - - s. ELAEAGINIFOLIUM. Fruit very prickly, lowest another much the longest,

s. ROSTRATUM.

s. TRIFLORUM, Nutt, Green, slightly hairy or nearly glabrous, low and spreading; leaves oblong, deeply pinnatifid with wide rounded sinuses; lobes 7-9; lanceolate, entire or 1-2 teeth; peduncles lateral-1-3 flowered; pedicels nodding; berries green, the size of a small cherry. Near Ranchos de Atrisco. July and August, 1908.

s. ELAEAGNIFOLIUM, Cav. ("Trompillo:") Silverycanescent with dense scurf-like pubescence of many rayed hairs, prickles small, slender; leaves from oblong to linear sinuate-repand or entire. Berry 1-2 in. 
or less in diameter, first green, then yellow, finally. black. Very common on campus, mesa and sandy places in valley and occasional in the mountains.

s. rostattum, Dunal. (Thomy N. Yellow N:) Annual, armed with straight prickles, somewhat yellow or hairy with a copious wholly stellate pubescence; leaves pinnifid or bipinnitifid; corolla yellow, stamens. and styles much declined. Bear Canon.

\section{CHAMAESARACHA, Gray.}

Perennials, with narrow, entire or pinnatifid leaves, tapering into margined petioles, filiform naked pedicels, solitary in the axils and recurved in fruit.

c. Conónopus, Gray, Green, glabrous or with some short rough hairs, diffusely very much branched; leaves lanceolate or linear, peduncles elongated, calyx with (often 2-forked) hairs; corolla yellowish. Near Ranchos de Atrisco.

3. PHYSALIS, $L$. Ground Cherry. Husk Tomato.

Herbs, with leaves often unequally in pairs; 1-flowered, nodding, extra-axillary peduncles. The groundcherry or husk-tomato of the gardens belongs here.

Some leaves sinuate pinnatifid, - - P. LOBÁT:

Leaves never pinnatifid, not glandulose-scurfy. Corolla dull-yellow with brown-purple, spots,

- - - - - - P. PUBESCENS.

Corolla ochroleucous with a more or less dark eye, - $\quad-\quad$ P. LANCEOLATA LAEVIGATA: P LOBATA, Torr. Low and small parts scurfy-granulated, otherwise quite glabrous, diffusely branched; leaves oblong-spatulate, some only repand, with margined petiole; peduncles usually in pairs; corolla violet 1-2 to 3-4 in. in diameter, the center with a 5 or 6 rayed wooly star; calyx in fruit globular inflated. Mesa.

P. PUbesceus, $L$. (Pubescent G.) Annual, strongscented, viscid, much branched, leaves ovate or cordate, corolla 1-2 in. broad or less; berry green at length yellow, anthers violet. Tijeras Canon.

P. Lanceolatea var. Laevigata, Gray. Either. glabrous thruout or some short hairs on young parts, stems from rather stout subterranean shoots, angled, somewhat rigid, leaves oblong to lanceolate, berry reddish. Common in the valley.

4. LYCIUM. Matrimony Bush.

Shrubby, mostly spiny plants with alternate small

(38) leaves, mostly axillary small flowers, 3 to 5 -toothed calyx not enlarging but persisting at baso of berry; calyx not enled red or reddish berry. (The commonly smanted matrimony vine with small yellow flowers belongs here.) Both of course are glabrous, with pale, spatulate leaves.

Corolla nearly 1 in. long, greenish, - I. PADDILUM. Corolla 1-2 in. long or less, whitish, - L. TORREYr. L. Pallidum, Miess. (Pallid M.) Leaves 1-2 in. long; pedicals about equaling the deeply 5-cleft calyx; corolla greenish, tinged with purple, with broad and rounded lobes; filaments exserted. On the stony hills of Terrace mesa, flower nearly always wormy. April 1908.

L. TORREYI, Gray. (Torrey's M.) Leaves sometimes over 1 in. long and $1-6$ in. wide; pedicels 1-6 to $1-4$ in. long; corolla white, cream-color or tinged with violet; stamens little if at all exserted filaments with valy at base. "Bear Cano, 1898" and on the Isleta Reservation in a sandy field where they form large clumps.

5. DATURE, $L$. Jimson-weed. Thorn apple. Rank, narcotic, poisonous weeds, with ovate leaves, large showy flowers on short peduncles. in the forks of the branching stem, corolla with spreading 5 to 10 branching stem, corolla with spreading .D. Meteiordes, $D$. $C$. Corolla white, suffused with violet, sweett-scented, 7 o 8 in. long when well developed. Along the streams and arroyos at the base of the Sandia Mts.

6. NICOTIANiA, Tourn. Wild Tobacco.

Rank acrid-narcotic, mostly clamy-pubescent herbs, with large leave s, racemed or panicled flowers; tubular, bell-shaped 5-cyeft talyx.

N. TRIGONOPHYLLA, Dunal. Leaves all-sessile or onil the lower tapering into a winged petiole; and obovate, upper obovate-olanceolate with a broader cordate half-clasping base, 1 to 4 in. long; corolla greenish white or yellowish, about 3-4 in. long. Among the volcanic rocks at the edge of the lava flow and on the Volcanoes.

17. POLEMONIACEAE. Polemonium Family.

Herbs with alternate or opposite leaves, corolla lobes convolute in the bud, 3-celled ovary and pod, the valves breaking away from the triangular center 
column.

Filaments not declined, naked at base, - GILIA Filaments more or less declined and usually pilose-ap pendaged at base - $\quad$ - - POLEMONIUiM GILIA, Ruiz and Pav.

Herbs, with narrow and acute calyx-lobes and tube scarious below the sinuses, corolla from salverform or funnelform to campanulated or almost rotate. In ours the leaves are alternate and pinnately incised, cleft or divided, or rarely entire.

Stamens unequally inserted.

Leaves all entire, sessile, ovules solitary,

- $\quad$ - $\quad$ - $\quad$ - $\quad$ - (1) 3. arAcrisis.

Leaves simply parted into narrow linear divisions. Corolla red, seeds numerous in each cell,

- - - (2) G. AGGREGATA. Corolla purplish, 'seeds в to $\mathrm{D}$ in each cell, (Stamens rarely equally inserted.)

- - - - (3) G. MULTIFLORA. Stamens equally inserted (but see also $N^{t}$ o. 3), leaves once or the lowest twice pinnate, ovules few or numerous in the cells, corolla violet purplish,

(4) G. INCONSPICUA 1. G. GRacilis, Hook. (Graceful G.) At length cormybosely much branched, more or less viscid-pubescent or glandular, 2 to 6 in. high; leaves lanceolate at linear or lowest oval; flowers loosely cymose 'or scattered; calyx rounded at base, its lobes subulatelinear, corolla purple or violet, its narrow tube yellowish. Bear Canon in Quercus gambeli Soc. 'May '08. 2. G. AGgregate, Spreng. False or Western Cardinal Flowerer). Somewhat pubescent; 2 to 4 feet high, leafy, leaves thickish with narrow, linear, mucronate divisions; panicle narrow, loose or interrupted, flowers sessile; corolla with long narrow tube. Resembles in color and habit Lobelia carlinalis of the East. Bear Canon and Tijeras Canon

3. G. MULtifloRA, Nutt. (Many-flowered G.) Many stemmed, a foot or so high, branches cinereouspubescent and calyx hirsute, tube of corolla less than 1-2 in. long and lobes 1-4 in.; stamens conspicuously exserted and the upper part of filaments incurved. Mesa, common about April.

G. INCONspicua, Dougl. Mostly low, slightly woolypubescent when young, and viscid glandular; corolla
1.4 to 2-5 in. long. Sandia Mts. Bear Canon and Hodgotite. May 1908.

POIEMONIUM, Tourn. Greek Valerian.

Jacob's Ladder Harebell.

Inflorescence racemiform or corymbose (in ours) coInflorescence raceme, showy, from funnelform to nearly rotate; stamens equally inserted; leaves all alternate, pin-1 nately compound.

P. Foliosissimum, Gray.. Very viscid-pubescent P. FOLIOSISSIMum, scented; stem very leafy thruthruout and or more high; leaflets from lanceolate to out, 1 concelaté; corolla white, -cream-color or violet, twice the length of the calyx; style and stamens not protruding. Bear Canon. Spruce-acre-Robina Association.

18. CONVOLVULACEAE. (convolvuLUS FAM.)

Chiefly twining or..trailing herbs, : with alternate leaves or scales; 2 (rarely 3 ) celled ovary with a pair of erect ovules in each cell, and fruit a globular 2 to 6 seeded pod.

Green leafy plants.

style single, stigmas $\mathbf{B} \quad-\quad$ convouvurus. Style $\mathbf{B}$, each $\mathbf{\mathbf { B } - c l e f t ; ~ s t i g m a s ~ l i n e ~ a r - f i l i f o r m ; ~ n o t ~}$ twining,

EVOLVULUS.

Leafless parasitic twining herbs, never green, custuTA.

CONVOLVULUS, :Tourn. (Bindweed.)

Herbs, twining or prostrate, with funnelform or companulate corolla, included stamens, style undivided or 2-cleft only at the apex.

C. Incanus, Vahl. Pubescent, stems filiform, 1 to 2 in. long, mainly procumbent; leaves from lanceolate to hastata or linear-sagitate, 1 to 2 in. long, $1-8$ to $1-4$ in. wide, some pedate or 3-5 parted; peduncles 1 to 2 flowered, as long as the leaf; sepals 1-4 in. long; corolla white or tinged.with rose, 1-2 in. - long. 'Tijeras Canon.

\section{EVOLVIUTUS, $L$.}

Low and small, usually diffuse herbs with 5 sepals, naked at base, open - funnelform or - almost rotate corolla; 2-celled, 4-seeded. pod. In ours the peduncles or pedicles are bibracteolate at base, solitary and 1-flowered, usually very short.

Corolla white or pale blue, 1-4 to 1-3 in. high or more. - . - - - - E. SERICEUS. Corolla purple, 1-4 in. long, - E. ARGENTEus. 
WATSON-Plants of Biernalitlo County

E. SERICEUs, Swartz-Sericeous excepting the glabrous upper leaf surface; stems slender or filiform, acuteleaves subsessile, lanceolate or linear-lanceolate, 1-2 to nearly 1 in. long, erect or ascending, mucronateacuminate or acute: silky pubescent fine and closepressed, sometimes short, whitish or fulvous; sepals ovate-lanceolate.

E. ARgenteous, Pursh. Many-stemmed from a somewhat woody base, dwarf,' silky villous all over; leaves crowded, broadly lanceolate, sessile; or the lower oblong-spatulate and short petioled, about 1-2 in. long; flowers almost sessile in the axils.

\section{CUSCUTA, Tourn. Dodder.}

Leafless, annual, parasitic herbs, with thread-like yellowish or reddish stems and twining on herb or shrubs to which they adhere by means of suckers; small, mostly white flowers in dense clusters. In ours the calyx is gamosepalous, orary and pod depressedglobose, capsule indehiscent and styles distinct, more or less unequal.

c. ARtensis, Bey. (Field D.) Stem pale and slender, low; flowers smaller than in many, scarcely 1-12 in. long; ealyx-lobes obtuse, mostly very broad; those of the corolla acuminate, longer than the tube, with in- flexed points; scales large, deeply fringed. In the more moist places on the mesa and in the valley. "On. various low plants."

19. ASCLEPIADEAE. MILKWEED FAMILY.

Plants with milky juice, opposite or' whorled, entire leaves, follicular pods, seeds and anthers, just as in the following family from which these differ in the valvate corolla; in the comnection of anthers with stigma and the cohesion of pollen.

asciepras, $L$. Milkweed Silkweed.

Perennial upright $\cdot$ herbs, with peduncles bearing simple many-flowered umbels; 5-parted, persistent calyx with small reflexed divisions; deeply 5 -parted corolla with reflexed deciduous divisions; crown of 5hooded bodies seated on the stamen tube and each containing an incurved horn, the two pollen masses of the adjacent cells unite and hang by their summits from 5 cloven glands that grow on the angles of the stigma; 2 ovaries and styles but one large 5-angled fleshy stigma, seeds 'with long silky hairs; flat.
Tulletin University of. New Mexico-No. 49

Irlowers orange-color, leaves mostly scattered,

Tlowers, greenish or lurid-purplish, leaves TEBROA. whorled or the upper rarely scattered.

Leaves narrow, lanceolate to linear,

Leaves large; orbicular to oblong lanceolate

A. JAMESII.

A. tuberosa, L. (Butterfly. weed.) Pleasant-root. Roughish-hairy; 1 to $2 \mathrm{ft}$. high; stems very leafy, ranching at summit; and bearing usually numerous numbels in a terminal corymb; leaves from linear to umbels in a tereolate, sessile or slightly petioled; hoods narrowly oblong, bright orange: Sandia Mts.

a BACHYSTEPHANA, Eugelm. Stems 6 to 10 inches high, very leafy, cinereously-puberulent or tomentose when young, the inflorescence more floccose; leaves 1 to $3 \mathrm{in.} \mathrm{long,} \mathrm{much} \mathrm{surpassing} \mathrm{the} 4$ to 8 flowered umbels. Mesa, common in spring.

JaMesII, Torr. Glabrous or minutely pubescent when young; stem stout, $1 \mathrm{ft}$. or more high; about 5 pairs of leaves, - very thick, rounded or broadly oval, subcordate at base, nearly sessile; umbels. 2 or 3, densely many flowered. At the base of the Sandia Mts.; and extending for some distance out on to the mesa.

20. APOCYNACEAE. Dogbane Family.

Plants ālmost all with milky acrid juice, entire, chiefly opposite leaves, without stipules; the corollalobes convolute and twisted in the bud. Styles and stigmas united into one.

APOCYNUM, Tourn. Dogbane.

Perennials herbs, with upright branching stems, tough fibrous bark, opposite mucronate pointed leaves, small and pale cymose flowers on short pedicels, 5parted calyx with acute lobes, bell-shaped, 5-cleft corolla, be aring 5 triangular appendages below the throat opposite the lobes, 5 stamens on the very base of the corolla, flat filaments shorter than the sagitate anthers, no style, large ovoid stigmas, seeds as in the milkweed (Asclepias.)

A. Cannabinum, L. (Indian Hemp.) Oynes clọe and many-flowered and usually shorter than the leaves, which are from oval to lanceolate, short petioled or sessile with rounded base; corolla greenish-white with nearly erect lobes. A good sized patch just wẹst

(43) 
of the Barelas bridge over the Rio Grande.

21. GENTIANEAE, (gENTIAN FAMILY

Smooth herbs with opposite sessile leaves without stipules.

sig'e fitiform, deciduous, anthers spirally twisting; age, parts' of flower 4 or 5 _ _ (1) ERTTHRAEA. Style stout and persistent, anthers remain straight

Coralla without nectar pits or large glands, funnel-form, parts 5 - $\quad$ - (2) Gentrana.

"Corolla with glands or pits. 4-parted, rotate

1. ERYTHRAEA, Richard. (Century.)

Low and small branching annuals, chiefly with rose purple or reddish flowers, funnelform or salverform corolla with slender exserted erect anthers, and oblong-ovate to fusiform pod.

E. Calroosa, Bucyley. Paniculately or somewhat cymosely branched; leaves from narrowly oblong to lanceolate or linear; inflorescence loose; pedicels mostly as long as the calyx or the flower; corolla-lobes oval or oblong, obtuse, 1-4 to 1-2 in. long, the tube usually equalled by the calyx. Towards Isleta in sandy fields.

2. GENTIANA, Tourn. Gentian. Calyx. commonly with a membraneous tube. Stamens on the tube of the corolla, style very short or none, seeds very numprous. Herbs with conspicuous flowers of various colors, late summer or autumn. Herbage and roots very bitter.

G. AFFINIs; Griseb. Stems clustered 8. in. or more high; leaves many, from oblong to line ar; flowers numerous or few; bracts lanceolate or linear; calyxlobes linear or subulate, unequal and variable, the longest rarely equalling the tube and shorter minute; corolla an inch or less long, rather narrowly funnelform, plicate at the sinuses and the plaits extended into lobes or teeth which are laciniate toothed or cleft and sometimes almost equalling the ovate, acutish, or mucronulate-pointed, spreading lobes. Sandia Mts. September. Quite common the south end of Rim Rock.

22. PRIMULACEAE. PRIMROSE FAMILY.

Herbs with simple leaves; regular, perfect flowers; calyx free from the ovary which has a central free pla- centa rising from the base and bearing several or many seeds.

ANDROSACE, Tourn.

Small annuals (ours), flowers white, umbellate, 5merous; stamens included, distinct; corolla salverform or funnelform, tube shorter than the calyx, the throat constricted.

A. SEPTENTRIONALIS, $L$. Almast glabrous; leaves A. lanceolatiate toothed, scapes erect, $2 \cdot$ to $10 \mathrm{in}$. high; to lacin of the small involucre subulate, lobes of calyx bracts of than the tube; lobes of the corolla shorter than shorter. Acaulescent, with slender root and an open the calate circle of leaves and naked scapes. Sandia Mits at about the $9000 \mathrm{ft}$. level.

23. UMBELLIFERAE. PARSLEY FAMILY.

Herbs with alternate, mostly compound leaves, whose petioles are expanded or sheathing at base; small flowpers, the calyx with its tube grown to the ovary and limb obsolete or minute so that there seems to be no calyx. A difficult order and fruit is necessary. Stamens and 5 petals fastened to a disk which covers the ovary. osmorreiza, Raf. Sweet Cicely.

Perennials with thick aromatic roots; more or less hirsute; leaves large, 2 to 3 ternately compound, involucre small or none; fruit linear oblong, flowers white. (Washingtonia.)

o. NuDA, Torr. Rather slënder, 2 to 3 ft. high; umbell long-peduncled, 3 to 5-rayed, style short. In the Aspen Society of the Sandia Mts.

24. ONAGRARIEAE. EVENING PRIMROSE FAMILT,

Herbs with usually 4-merous, perfect and symmetrical flowers; no stipules; ovary 2 to 4-celled; stamens inserted on the summit of the calyx-tube, a single slender style and a 2 to 4 lobel or capitatestigma.

Fruit a many-seeded usually loculicidal pod.

Seeds suky-tufted; flowers small, rose or pur plish; lower le aves often alternate

(1) EPILOBIUM.

Seeds naked; flowers rose or yellow, leaves alter nate, - - - (2) OENOTHERA. Fruit dry and indehiscent, 1 to 4 seeded, leave alter nate - - (3) GUARA. 1. EPHILOBIUM, $L$. Willow-herb.

Mostly perennials with nearly sessile leaves, violet 
or purple or white flowers, calyx tube scarcely prolong ed beyond the ovary and with a 4 to 5 lobed deciduous limb, 4 petals, 8. stamens, with short anthers and a linear capsule.

E. ADENOCAULON, Haussic var PERPLEXENS, Trelease.

Simple. or nearly so, almost smooth below, mostly canescent with incurved hairs in the inflorescence; leaves 1 to 2 in. long, divergent, lanceolate, rather obtuse and sparingly undulate-serrulate, more or less tapering into a shortpetiole; flowers small with rosecolored petals; seeds obovoid with a turf of white hairs.

E. Coloratidur. Stem ercet 1 to $3 \mathrm{ft}$. high, glabrous or nearly so; leaves lanceolate to ovate-oblong, denticulate; the middle ones sometimes decurrent; hte lower slightly petioled; flower-buds erect, petals purplish, emarginate or 2-cleft; pods minutely pubescent. Bear Ganon. This plant may belong to the next species.

E. NeO-MEXICANA, Hamker. Leaves all (excépt the very uppermost sometimes) petioled, other wise very similar to last. Sandia Mits., June, 1908.

2. OENOTHERA, $L$. Evening-Primrose.

Plants with altermate leaves, yellow or white, or rose-colored flowers, decidulous calyx-tube prolonged beyond the ovary and with 4 reflexed lobes, 4 petals, 8 stamens with mostly linear and versatile anthers, and a 4-valved capsule.

Caulescent capsule sessite.

Flowers erect in the bud, yellow, capsule oblong, seeds 2 rows in each cell, - (1) OE. JAMESII.

Flowers nodding in the bud, white, turning to rose, capsule linear, seeds in one row.

Annual or biennial, '(2) OE. PINNATIFIDA.

Stems from a perennial subterranean rootstock.

Throat of calyx naked (3) OE. ALBICAULIS.' Throat very villous (4) OE. CARONOPIFOLIA Acaulescent, capsule oblong, flowers erect in the bud

-.. - (5) oE. CAESPITOSA, Nuitt. 1.ok. JaMesir, Torr and Gray, (The Acequia E.-P Tall E. P.) Stout, 5 to $10 \mathrm{ft}$. tall, becoimng thick and woody at base; pubescence appressed, canescently puberulent: with scattered hairs, calyz-tube 3 to 5 in. long; capsule 1 to 2 in. long." In the valley along acequias, etc.

(46) oe. PinNatifida, Nutt: Stem decumbent at base 2. OE. PINN branched or subsimple and erect, 3 and 12 inches high, conescently puberulent or sub-hirto 12 leaves oblanceolate or linear-lanceolate, 1 to 3 in. long, mostly deeply sinuate-pinnatifid or entire; calyxtips not free, the throat naked; seeds oval, not angled, finely pitted. Campus Uni, N. M. Mesa generally.

3. albicaUlis, Nutt. Stems erect 6 in. to $3 \mathrm{ft}$. or more high, white and often shreddy; glabrous or pumore teav's line ar to oblong-lanceolate, 1 to 3 in. berlent; leaves attenuate at base or abruptly petioled, long sess repand-denticulate, or sinnate-pinnatifid towards the base; calyx tips free. Sandy. field near Barelas bridge.

4. Oe. CORONOPIfolia, Torr and Gray. Stems erect, branched 6 to 18 in. high; canescently puberulent, often more or less hispid; le aves narrowly oblanceolate, 1 to 2 in. long, sinuately pinnatefid or more usually pectinate-pinnatifid, the linear segments as broad as the rhachis; calyx-tips short, free; seeds ovate, angled, tuberculate. Bear Canon.

5. oz. CaEspitosa, Nhutt. ("Primrose.")' Capsule ribbed, of ten doubly; crested on the angles; calyx-tube 2 to 7 in. long; petals 3-4 to $13-4$ in. long, white or rose-color. Common on the mesa in spring.

\section{GAURA, $L$.}

Herbs, with mostly sessile leaves, white or rose-colored flowers in spikes or racemes and obconical desiduous calyx-tube, much prolonged beyond the ovary and with 4 reflexed lobes, clawed petals, mostly 8 stamens with a small scale-like appendage before the base of ach filament.

G. Parvirlora, Dougl. (Small-flowered G. Tall G.) Soft villous and puberulent, 2 to $6 \mathrm{ft}$. tall; leaves ovate-lanceolate, repand-denticulate, soft pubescent; spikes dense; fruit ablong-clavate, narrowed at both ends, 4-nerved, obtusely angled above, 1-4 to 1-3 in. long. In alkali soil along the valley.

a. Coccines, Nutt. Canescent, puberulent or glabrate, very le afy, 6 to 12 in. high; leaves lanceolate, linear-oblong or linear, repand-denticulate or entire; flowers in simple spikes, rose-color, turning to scarlet; fruit terete below, 4-sided and broader above 1-6 to 1-4 in. long. Common on the mesa especially in late spring and early summer. 


\section{W:ATSON- Plants of Bernalillo County}

25. LOASEAE. LOASA FAMILY.

Herbs with either stinging or jointed and roughbarbed hairs, no stipules; calyx-tube adnate to a 1-celled ovary; perfect, often showy flower, usually very numerous stamens; and a single style.

\section{MENTZELIA.}

Stamens many, inserted below the petals; style $\Im$ eleft at apex, seeds few to many on 3 parietal placentae.

Annual and biennial erect herbs with stems becoming white and shining, alternate leaves, very adhesive by the barbed hairs; terminal, solitary or cymose-clustered, yellowish or white flowers; cylindrical or clubshaped calyx tube with a 5-parted persistent limb; 5 regular, flat,spreading, deciduous petals; usually indefinite stamens. In the mountains.

Seeds few or many, petals 5, not large, filaments all filiform, (1) M. ALBICAOLIS.

Seeds numerous, winged, petals 10 often large and showy outer filaments petaloid, - (2) M. NUDA. 1. M. ALBICAULIS, Dougl.

Slender, 3 to 12 in. or more high; leaves. linearlanceolate, pinnatifid with numerous narrow lobes; sessile, upper leaves broader; flowers mostly approximate, near the ends of the branches; petals spatulate or obovate; capsules linear-clavate with many seeds which are tuberculate and irregularly angled.

2. M. NUDA, Torr and Gray. Rough, leaves lanceolate, sessile, sinuately-toothed or pinnatifid, the segements obtuse; flowers opening in the evening, yellowish-white, rather large, not bracteolate, capsule broad, oblong, 3-valved at the summit.

26. CACUTACEAEE. CACTUS FAMILY.

The leaves are small or wanting, but the stems are often flattened and are popularly considered leaves. Bundles of spines arise from the areolae which constitute the axils of the leaves.

No proper leaves, spines never barbed, flowers and spines on separate areolae, tube of flower long or least well-developed.

Globose or oval, ovary naked, (1) MaMmLLARIa.

Oval or columnar, ovary covered with sepals,

$$
\text { -. - (2) cereus. }
$$

Leaves small, subulate, early deciduous; flowers and spines from the same areoae, spines barbed; tube of flowers short, cup-shape,.. -.. (3) OPUNTIA.

\section{Bulletin University of New Mexico-No. 49}

\section{MAMTLLARIA:}

Small simple or cespitose plants, the spine bearing reolae borne on cylindric, oval, conical, or angular tubercles which cover the body of the plant; flowers about as long as wide, the tube campanulate or funnelshaped, from a distinct wolly or bristly areola at the base of the tubercles, fully open in sunlight and only for a few hours. In ours the flowers arise from the base of a groove on the young tubercles, flowers red or reddish, sepals fimbriate.

м. strobilormis, Sacheer. Ovate or ovate-cylindrical, 2 to 5 in. high, tuberles spineless and corky.in age, very villous axiles, outer spines $20-30$, rigid, white 1 $1-2$ to 3 in. long, rarely 4 or 5 in.; inner ones 5 to 9 , stouter 3 to 7 in. long grayish purple. Flower very pale purple, berry red 7 in. long and 1-2 in. thick. Sandia Mts. July.

M. vivipara, Haw. Simple or cespitose, 1 to 5 in. high, tuberles round, loosely arranged, slightly grooved, 3 to 5 in. long; spines straight, rigid; the exterior widely radiate, white, $12-36,2-8$ in. long; the central 3-12, stouter, longer, darker, a single more robust one perpendicular or deflexed; flowers a beautiful purple, large 1 1-2 to 2 1-2 in. diameter; berry ovate, green; seeds light brown pitted. Sandia Mts. May.

\section{CEREUS, Haworth}

Flowers close above the bundles of full grown older spines, scales of ovary distinct with naked or woolly. axils, berry sometimes very large and edible and covered with spines or scales or almost naked. The plants are ribbed instead of tubercled. In ours 5-13, with 3-12 spines, in each areolae which are 1-4 to 1-3 in. long.

Flowers purple, diurnal,.. - .. $-\ldots$ c. FENDLERI. Flowers scarlet, open day and night, c. PaUcispinús.

C. TENDLERI, Eng. Ovate-cylindrical, 3-8 in. high; ribs 9-12, spines from a bulbous base; rádicals 7-10, straight or curved, some white, some grayish brown, some variagated,2-5 to $1 \mathrm{in}$. long the lower ones" stouter; central one stout, curved, blackish-brown, often elongated 1 to $13-4$ in.; flowers lateral and near the apex 2 and 1-2 to 3 and 1-2 in. across, deep purple; berry 1 in. or more long. Sandia Mts. May.

c. PaUdispinus, Eng. Ovate-cylindrical, 5 to 9 in. high, 2 to $3 \mathrm{in}$. in diameter; ribs 5 to 7 ; areolae re-

$(49)$ 
mote ; 3 to 6 stout radiating dark-colored spines, $3-4$ to 1 and $1-3$ in. long.

\section{OPUNTIA, Tourn}

Articulated, much branched, plants of various shapes, low and prostrate or erect and shrub-like; areola with numerous short easily detached bristled and usually stouter spines; mostly large diurual flowers on joints of the previous year; spreading obovate or obcordate petals. There are several of this genus in our locality which the anthers has not yet identified.

Joints quite flat, seed with a prominent bony margin. Joints large, 6 in. long or more, berry ovate (1) o. CaManCHICa, Eng.

Joints smaller 2 and 1-2 to 3 in. in diameter,

$$
\text { - - - - - (2) o. FUSCO-ATRA. }
$$

Joints little flattened, ovate; low, cespitose,

-.. - . . . . - . - . -. (3) o. FRÁgILIs. Joints cylindrical, erect, branched (4) o. ARBORESCENS.

1. o. Comanchica, Eng. Prostrate and extensively spreading; joints ascending, suborbicular, 6 to 7 , in. long; pulvilli remote, mostly bearing few straw colored or fulvous bristles and 1-3 compressed grayishbrown spines (in some they are twisted. This may be 0 . tortispina but there are only 1-3 spines) paler at the tips, the upper ones suberect elongated, the rest deflexed 1 and 1-2 to 3 in. long. Mesa

2. o. FUSCO-ATRa, Eng. Diffuse; joints orbiculateovate, tuberculate, pulvini somewhat remote, large, grayish, tomentose, only the lower armed; bristles numerous; stout, rather long (1 and 1-2 to 2 and 1-2 in.) grayish-brown; spines usually a single stout brownish-black, suberect one (1 to 1 and 1-2 in. long) often another shorter deflexed one; flowers yellow, nearly 3 . in. in diameter with a conical ovary bearing pulvilli covered with long grayish-brown wool. Lower slopes of the mountains.

3. o. Fragilis, Haw. (The Frigile O. ) Joints small, 1 to 1 1-2 in. long; larger spines 4 , cruciate; mostly yellowish-brown with 4 to 6 smaller white radiating ones below; bristles few; flowers yellow; fruit with 20 to 28 clusters of bristles, only the upper ones with a few short spines. Very common on the mesa forming patches several feet across. The most common of our mesa cacti. o. ARBOREsCens, Eng. ' "El Candelabria." "Cane o. Aactus,") 5 to $6 \mathrm{ft}$. or more high; spines 8 to 30 , divaricately stellate; flowers large, purple; fruit nearly hemispherical, yellow, unarmed, and almost dry. Very common on the lower slopes of the mountains and the adjoining mesa. Occasional only on the mesa generally.

27. VIOLARIEAE. VIOLET FAMILY.

Perennial herbs with alternate stipulate leaves, 5 persistent sepals and a 1 spurred corolla. VIOLA, Violet.

v. CaNadensis, $L$. Upright, $1 \mathrm{ft}$. or so high, leaves cordate pointed, serrate, stipules entire; petals white at least inside but often tinged with purple beneath, the lateral ones bearded, spur very short. Bear Canon in Spruce-Acer-Robinia Association.

28. MALVACEAE. MaLlOW FAMILY.

Ours herbs, with alternate stipulate, mostly palmate leaves, 5 persistent sepals united at base and (in ours) with three bractlets; carpels closely united into a ring around the axis from which they separate after ripening.

SPHAERALCEA, St. Hitaire.

Stigmas capitate, carpels 2 or 3 -seeded or sometimes 1.seeded.

Carpels 1 to 2-ovuled and the upper abortive, no thread holding them to the axis.

Leaves palmately parted, petals orange-red

- - - - - - mostly cordate, petals white or rose color, - - : is. AMBIGUA.

Carpels 2 or 3-ovuled and 1 to 3 seeded, cohering to the axis by a thread, leaves lanceolate to linear, serrate but not lobed, - - - - s. ANGUSTIFOLIA

s. PEDATA, Torr. $2 \mathrm{ft}$. high; flowers large, petals often 3-4 in. long; carpels always 1-seeded. Sparsely stellate-hirsute.

s. aMbigUa, Gray. Closely canescent with stellate hairs; leaves merely crenulate toothed; petals $1-2$ to 1 in. long; near Ranchos de Atrisco.

S. ANGUSTifolia, Spach var CUSPIDATE, Gray. Stems branching, 1 to $2 \mathrm{ft}$. high; densely stellate pubescent; Jeaves rough veiny, serrate, petals red. Campus. Aug. 1907. 
29. AMPELIDACEAE. Vine FamiLy.

Shrubs climbing' bv tendrills, with alternate pal: mately-veined or compound leaves, tendrils and clusters or small greenish flowers opposite the leaves.

Palnts climbing by the coiling of naked-tipped tendrils, - - : - - - (1) vITTS Climbing by the adhesion of the dilated tips of the tendril branches, - . - - (2) AMPELOPSIS. 1. VITis, Tourn, Grape.

v. ARIzoNica, Engelm. (Arizona grape.) Branches angular; leaves cordate, obscurely if at all lobed, "cottony when young, glabrous when older, thick, rigid and rough. Berries small or middle-sized. Common in the more mesophytic -canons.'

- 27\% am a pelopsis, Mt. Virginia Creeper, American Ivy.

A. Quinquefolia, $M x$. Léaflets mostly 5. Commonly planted and rarely wild in the mountains. Tijeras Canon, climbing over rocks. (Look for A. heptaphÿlla with smaller, six or seven leaflets. 'It may grow" here:)

30. RHAMNEAE, BUCKTHORN FAMILY.

Shrubs or small trees with simple undivided leaves, small and often caducous' stipules, small flowers, a conspicuous disk lining the calyx tube; valvate calyx.

cfanothus, L. New Jersey Tea, Red Root.

"Shrubs, spinose or unarmed (in ours); with alternate leaves, three-nerved, and small but showy white flowers, in dense clusters (racemes in ours.)

c. FEndLeki, Gray; Silky pubescent, leaves narrow1y-oblong to elliptic, 1-3 to 1 inch long, entire and somewhat coriaceous. Mountains in the Quescus-undulatus jamesii Society especially. . July.

31. CELASTRINEAE, STAFF TREE FAMILY.

Low shrub, with small, 'dull-colored 'flowers, and stamens inserted on a broad disk, which lines the calyxtube.

PAChystima, Raf. 'Western Strawberry' Bush

Calyx with a short tube, and 4 rounded lobes; petals four; ovary free, 2-celled; style very shcrt. Seeds enclosed in a white membranaceous aril.' 'Low "evergreen shrub, leaves smooth, "opposite, very shortly petioled, serrate or serrulate. "Flowers green," but in ours quite reddish.

P. MYRSiNites, Raf. Leaves ovate to oblanceolate, (52) cuneate at base. High up on the Bear Canon Forest Reserve trail, among the rocks of the Aspen Society. May.

3. SAPINDACEAE. SOAPBERRY $F$.

Ours trees with compound or lobed leaves; ovules Ours trees solitary. One suborder is represented few but commonly planted Horsechesnut, AEsculus by the coum, and the Ohio Buckeye, AE. glabra; has Jippocastaum, and Ours belong to the suborder ACERTirregular flowers polygygamous or dioecious, regular NEAE with flowers pouls, leaves opposite, without often withuit consisting of the well known double stipules; fruit consistin.

samara of thatmately lobed; flowers polygamious, ACER. Leaves pinnate; flowers dioecious, apetalous NEGONDO. AcER, Tourn, Maple.

A. GLabrum, Torr. Shrub 6 to 10 feet high, leaves subreniform, orbicular in outline, 3-lobed or more usually 3-parted, segments short and broad, acutely incise and toothed, somewhat 3-lobed, middle one cueate. Olose to the streams in the Sandia Mountains among the Spruces.

NEGUNDO, Moench, Box-elder.

A good-sized tree, quite common along the streams in the canons of the mountains and one of the most successful when planted in town.

N. ACERoIDEs, Moench, (Maple-like B.,) A tree with light green twigs and very delicate drooping clusters of small greenish flowers, appearing rather earlier than the leaves whcih have generally three, sometimes 5, leaflets, smoothish when old, very veiny, ovate, pointed, toothed; fruit smooth, with lärge, rather incurved winugs.

33. ANACARDTCEAE. SUMACH FAMILY.

Ours shrubs with alternate simple or compound leaves without stipules, small regular, polygamous or dioecious flowers; fruit a dry drupe (i. e. a one-seedod hard fruit surrounded by a fleshy portion,) much relished by birds.

Rhus, L. Sumach.

Sepals and petals usually $\mathbf{5}$, stamens inserted under the edge of a disk lining the base of the calyx...

Leaflets 11 to 31.

Whitened underneath, - - R. GLABRA. Paler underneath, - - : R. SARBIFOLIA. 


\section{Leaflets 3.}

Short petioled,

R. TRILOBAT TA

With a very long petiole, - R. RYDBERGI

R. GLABRA, $L$ : (Smooth S.) Shrub 2 to 12 feet high; leaflets whitened be neath, lanceolate-oblong; pointed, serrate; fruit globular, clothed with acid crimson hairs; the stone smooth. In the canon above Camp Whitcomb:

R. TRILOBATA, Nutt. (Scented S.)

A shrub 2 to 5 feet high, diffusely branched, strongly scented, leaflets cuneate-obovate, or rhomboidal, coarsely toothed above and often 3-lobed; flowers in clusters, scaly, bracted spikes like catkins, preceding the leaves, yellowish ; fruit flattish, somewhat vis-. eid. Common in the $E l$ Candelabria Society at the base of the mountains.

R. Sarbifolia, Green.

A sepecies so marked in the herbariam collected in June, '08; seems t o be very similar to R. glabra except in the paler lower surface of the leaves. It is quite possible that my Rhus glabra belongs here.

R. RYDBERGII, Small.

Resembles somewhat the "poison ivy" of the East in leaf and raceme. The petioles of the leaves are some one foot long. Leaflets e ach coarsely toothed, ovate sometimes 3 inches long; nearly glabrous, very green "above, paler beneath. Cbllected by C. L. Herrick in Sandia Mountains, June 1898. I have not found the plant growing.

34. EUPHORBIACEAE, Spurge Family.

Monoecious or dioceeious, mostly apetalous but sometimes polypetalous flowers; ovary with a single ovile (sometimes 2) hanging from th summit of the cell and maturing in a mostly 3-celled elastically dehiscent pod. This difficult family has been imperfectly worked. It is certain that there are other species in our range. The identification is difficult for a beginner.

Flowers all without a calyx, collected in a cup-sheaped calyx-like involucre, - - - .. EUPHORBIA.

Flowers with a calyx and no involucre.

Whitened with a close stellate pubescent, cRoToN:

With long coarse stinging hairs, . - - TRAGIA.

EUPHoRbia, L. Spurgè.

Herbs (ours), wit hmilky, bitter juice; what looks , like the single flower to the novice is a head, which in-

(54) ludes in the bottom numerous stamenite flowers, each. with a single stamen, and in the center, on a stalk, the with a singtillite flower (apparently the pistil of the solitary pistll, with three 2-cleft styles; the whole sursingle the by the 4 or 5-lobed involucre which looks like rounded by the supposed flower.

E. FENDLER, Tarrand Gray. Glabrous. Annual E. FEN slender root-stock; stems delicately filiform, rrect or decumbent, dichotombusly much branched, 2 to 4 inches high; leaves ovate, entire, obtuse, rounded at base. Common on mesa and especially. in the more sandy parts of the valley.

Croton, $L$.

Our herbs, somewhat woody at the base, leaves alterOur hith stipules. Ours dioecious staminate flowers with a 5-parted calyx; 5 petals; as many glands of the disk alternate with the petals; 5 or more stamens; pislillate flowers. 5 to 10 cleft or parted (5-parted in ours), petals none or mere ruiments, 3-celled ovary separating in fruit into as many 2-valvaed, one-seeded carpels.

C. TEx Ensis, Muell. Annual, 1, to 2 feet high; leaves narrowly oblong, lanceolate to linear, 1-1-2 to 1.4 nches long, short petioled; stamenite spikes or racemes very short often sessile. Common everywhere on the mesa, abundant on the more sandy parts of the mesa and valley and the lower parts of the mountrains, and on the alluvial fans of which it is often chief plant.

Tragia, $L$

Alternate leaves with stipules, monoecious, aeptalous, small flowers in terminal or lateral racemes with the fertile flowers below the stamenite; sterile calyx 3parted; pistillate 3 to $8 ; 2$ or (in ours) 3 stamens with short filaments and united anther cells; 3-cleft style; 3-celled, 3-lobed bristly pod separating into three 2valved 1-seeed carpels.

F. Nepetaefolia, Cav. (Nettle-leaved T. Stinging:T.)

Erect, reclining, or slightly twining, leaves ovate, lanceolate or triangular-lanceolate, cordate or truncate at base, coarsely cut, toothed, short petioled. Under the edge of rocks in the Pinon-El Can delabria Society of the Sandias Mountains.

35. POLYGalEAE, (Milkwort Family.e

Ours herbs, with simple etnire leaves; no stipules; flowers resembling superficially those of the Pea Fam- 
ily, stamens in ours monadelphous, coherent with the petals.

Poligara, Tourn. Milkwort.

Flowers in recemes or spikes; 5 very unequal sepals, the two lateral ones enlarged like the wings of a pea ; 3 peteals unitd to each other and the stamen tube, the middle one hooded above and with a small ". (in ours) crest; 6 to 8 stamens with filaments united below into a split sheath, pods flattened at right angles to the narrow partition. Ours belong to the section with leaves narrowly linear or subulate; flower white or greenishwhite.

P. Alba, Nutt. (White M.) Stems several from a hard root-stock; leaves acute, 1-4 to 1 inch long. "Four miles south of Tijeras." July, 1898.

\section{STMARUBACEAE}

Much like Rutaceae but no dots on the leaves.

Airlantmus glandulosus, Desf. "Called Tree-ofHeaven (because of its tall growth), but whose blossoms especially the staminate ones, are redolent of anything but 'airs from Heaven.?" (The only joke in Gray's Botany.) Commonly planted in town : and spreads rapidly by means of shoots from the roots. There are many around the :pumping station of the City Water Supply Co. The leaves are often over 2 ft. long, and pinnately compound; dioecious fruit a samara.

\section{RUTACELAE, Rue Family.}

Trees, shrubs, or herbs; opposite or alternate leaves; generally regular and symetrical flowers, $4-5$ sepals, in ours as many stamens inserted outside of an hypogynous disk.

Prelea, $L$. Shrubby Trefoil. Hop-tree.

Leaves 3-foliate, flowers greenish-white; small, polygamous, in compound terminal cymes; and broadlywinged, orbicular fruit.

P. Trifoliata, L. var molisis, T. and $G$. Shrub or small tree; ovate leaves downy below as are also the branchlets and petioles. Common in the Spruce-AcerRobinia Association and the Quercus undulata jamesii societies of the/mountains.

\section{IINEAE. Flax Family.}

Lindi, Tourn. Flax. Herbs with tough fibrous 'bark, alternate sometimes opposite)', sessile le. aves without stipules or- with glands in their place; persis- tent sepals and ephemeral petals.

L. Vernale. Spring Flax. Petals a dull orange yellow or buff with a darker center. Common on the mesa in spring.

39. ZYGOPHYLLEAE. BEAN-CAPER FAMILY.

Ours herbs with symmetrical 4 or 5 -morous flowers, solitary on lateral or termlinal naked peduncles; a single style terminating a 2 to 20 -carpeled ovary which ripens dry.

\section{Tribulus, $L$.}

Loosely branched hairy prostrate herbs with abruptly pinnate, opposite, leaves and the alternate ones smaller or wanting; solitary, axillary, white or yellow flowers, 5 sepals and petals, and 10 stamens and a lober fruit separating from the persistent axis.

T. Maximus, $L$. (Larger T.) Stems long; leaflets 3 to 4 pairs, ovate-oblong, 1-4 to 1-2 in. long, oblique; peduncles $1-2$ to 1 in. long; sepals very hairy, linear, acuminate, 1-6 in: long; petals a half larger; fruit 1-6 in. high, beaked by a.stout style about as long, and carpels roughly tuberculate. In sandy soil in the valley.

T. Grandiflonus; Watson: Hispid with usually longer and more spreading hairs; leaflets 4 to 6 pairs; peduncles longer; sepals 1-4 to 1-2 in. long; the petals usually twice longer. Along the railroad north of Central Avenue.

40. GERANIACEAE, Geranim Family.

Herbs, leaves compound or lobed, regular 5-merous flowers on axillary pe duncles, 5 to 10 stamens.

Leaves lobed but not compound, (1) GERANIUM. Leaves compound (in ours)..

Pinnate; fertile stamens 5, - (2) ERodium. Palmate, staimens $10:-$ : $^{-}$(3) oxalis.

1. Geranium; $L$. Cranesbill. Annual or 'perennial herbs with palmately lobed and mostly oppsiote leaves, scarious stipules, axillary peduncles $b$ earing 1 to 3 violet or rose-colored flowers.

G. Atropdrpuredm, Heller. Perennial from a stout caudex, more or less decumbent, "spreading, caespitose canescent; leaves incisely 3 to 5 -parted, the wedge-shaped divisions again cleft; petals purple-longer than the prominently awned sepals. Sandia Mts. in Quercus gambelii and Spruce-Acre-Robinia association and the Yellow Pine Soc.

2. ERodrum, L. Her: Storkbill. Like gera(57) 


\section{WATSON-Plants of Bernalillo County}

nium but only 5 stamens, the carpel tails long bearded and becoming spirally twisted and by their movements burying the seed, flowers smaller.

E. Crcutarium, L. Her. Hairy, much branched from the base; peduncles bearing a 4 to 8 -flowered umbel; sepals 1-12 to 1-4 in. long, acute; petals bright rose-color, a little longer; tails of the carpel; 1-2 in. long. Introduced from Europe but quite common about dwellings etc. In "Highland Park (?)" and at the month of Tijeras Canon, where it bloomed as early as February 2, 1908.

3. Oxalis, L. (Wood-sorrel). Low, in ours acaulescent herbs with a sour juice, alternate 3 foliate leaves (like a clover.)

O. Violaces, $L$. Leaflets about 1-2 in. long, scapes several longer than the leaves, 3 to 12 flowers in an umbel, sepals ovate obtuse with a 2 or more orange callosities on the tip; petals 3 times as long, rose-violet. Among the Spruces and Firs of Bear Canon and its branches.

(Look for $O$. vespertitionis with 4 to 6 callosities, see Bot. of Western Texas P. 52).

\section{LEGUMINOSAE. Pea Famils.}

Plants with alternate stipulate usually compound leaves, papillionaceous (in 1 suborder regular) flowers; 10 (rarely 5 or many) monodelphous, diadelphous or rarely distinct stamens. After the compositae. the largest of our families.

Suborder I. Papilionacene. Leaves simple or once compound, flowers papilionaceous, (wit hlarge petal on top-standard, two smaller wings, and the two lower ones united into a keel)

A: Stamens 10 and distinct. (See Amorpha). Leaves digitately 3-foliate,

(1) THERMOPSIS. Leaves unequally pinnate, thick, (2) SOPHORA.

B. Stamens monadelphous or diadelphous.

*Leaves palmately or pinnately 3-foliate; leaflets denticulate or serrulate; stamens diadelphous; pods small; one to few-seeded; often inclosed in the calyx or curved or coiled.

Flowers racemed, pods coriaceous, wrinkled, 1 or 2 seeded,

(3) MELILOTUS.

Flowers in a head, pods 4 to 6 -seeded; petals adherent to the stamen tube, - - - (4) TRIfolium.
Bulletin University of New Mexico-No. 49

* Leaves unequally pinnate or palmate in Psoraleo and some Dateas; no tendrils.

8Herbage glandular-dotted; stamens monadelphous; pods small, indehiscent, mostly 1-seeded.

Corolla truly papilionaceous stamens 10, half of the anthers often smaller or less perfect

- - : - - (5) PSORALEA.

Corolla of one peteal, stamens 10, monadelphous at base,

(6) AMORPHA.

Corolla imperfectly papilionaceous; stamens т. or 10 ; the cleft tube of filaments bearing 4 of the petals about its middle,

(7) DALEA

Corolla scarcely at all papilionaceous; stamens $\mathrm{E}$; the cleft of tube of fliaments bearing. four of the petals on its summit, - (8) PETALOSTEMoN.

${ }^{88}$ Herbage not glandular-dotted (except in gly.crrhiza); stamens mostly diadelphous; pod 2-valved; several seeded; flowers racemose.

Tree or shrub, wings free, standard broad,

- - - - - (9) ROBINIA

Perennial herbs, standard narrow, pod inflated. Kell tipped with an erect point.

Kell not tipped with an erect point.

Pod smooth; sutures turned in

Pod prickly or muricate

(11) astragdLUs.

- (12) GLYCYRRHIZA.

**Herbs with abruptly pinnate leaves terminated by a tnedril or bristle, stamens diadelphous, pod 2. valved, few to several-seeded.

Wings adherent to the keel; style filiform, bearded with a tube or ring of hairs at the apex (13) vrcra.

Wings nearly free; style somewhat dilated and flattened upwards, bearded down the inner face,

Sub-order II. CaESALPINIEAE Fl(14) LATHYRUS. onaceous, sometimes nearly. regular, the upper petal inclosed by the others in the bud; stamens 10 or fewer, commonly distinct, inserted in the calyx. Ours are shrubs.

Leaves simply and abruptly pinnate, not glandularpunctate, - - - - - (15) CASsia. Leaves bipinnate, with or without black glands,

(16) HoFmMANSEgGia. 
1. Thermopsis, $R . B r$.

Calyx campanulate, cleft to the midle. Standard shorter than the oblong wings, the sides reflexed; keel nearly straight, equalling the wings. Pod. linear to oblong-linear, much compressed, shortly stipitate or nearly sessile, straight or incurved. Stout perennial herbs with erect clustered stems; stipules free, leaflets entire.

T. Montana $i$ Nutt. Somewhat silky-pubescent; at length glabrous; stipules exceeding the petioles; leaflets oblong, slightly villous beneath, smooth above bracts mostly lanceolate, pod straight, erect pubescent 10 to 12. seeded. Sandia Mts.

\section{SopHORA, $L$}

Calyx camponulate; teeth short; petals nearly equal; standard broad. Pod stipulate, terete or somewhat compressed. Ours are herbs with numerous leaflets entire; stipules small or lacking, white flowers in terminal racemes. Orbicular fruit.

S. Sericea, Nutt. Low, 6 to 12 in. high, more or less silky canescent; leaflets about 21 , elliptic or cuneate-oval; racemes short, at first scarcely exserted beyond the leaves; calyx gibbons at base.

3. Melmotus, Tourn. Sweet Clover.

M. AlbA, Lam. (White S. C.) Leaflets truncate; the standard longer than the other petals. On Campus Univ. of N. M. and in the less dry places in the valley. An introduced plant.

4. Trifolidm, ' $L$. Clover.

Too well known to need description, all are introduced plants except the last.

T. Pratense, L. The common Red Clover of the East is very scarce here but rarely a plant is seen about yards and laws.

T. Repens, $L$. The low White Clover of the East is often planted in lawns and occasionally grows independently.

T. Allfalifi, Alfalfa is the great forage crop of the valley and commonly escapes and grows 'without cultivation even in such dry places as the mesa, when protected from grazing:

T. Procumbens, the low yellow or hop clover of the East grows wild along one of the irrigation ditches on the Univ. Campus.

'T. 'LONGIPES, Nutt var. Latifolrum, Hooker.
Slender; stems usually glabrous, the leaflets and calyx sparingly villous; leaflets narrowly obong in the sparing but wider in the variety, iserrulate; flowers specioleticous or tinged with purple, a clover occasionally met with among the Cottonwoods along the river aly to belong to this species.

\section{Psomaitia, $L$}

Perennial herbs, palmately 2 to 5 foliate leaves, bluepurplish or white flowers in spikes or racemes.

$P$. Ouspidatia, Puirsh. Stout änd tall from a deep scated tuber, hoary with appressed hairs; leaflets usualls broadly oblancélate; öbtuse; flöweris large; petals $1-2$ to $2-3$ in. long; exceeding the lanceolate-lobed calyx.

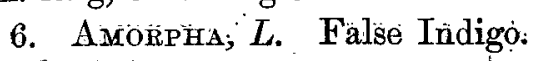

Shrubs with violet or purple flöwèrs crótided in clustered terminal spikes.

A. Fruticosa, $L$. Pubesceñt or nearlÿ glabroús'; leaflets 8 to 12 pairs, oblong to elleptical, sciattered; calyx somewhiat pubescent, the lóweer tooth acuminate and longest, the others commonly obtuse; ; standard purple, deèply emarginate; pod 2 -seeded. In the alkali soil along the river; êspecially west of Barelas bridge. " A pretty shrub.

\section{7. "DA⿱亠䒑EA,$L$.}

Herbs or shrubs with odd pinnäte (rarely palimatè) leaves, small entire leäflets; flowers in têrminal peduncles" spikes.

Calyx vériy villous; with long sibuilate teeth.

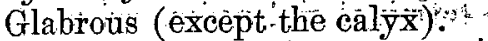

Low shrubs; spikes few flowered (1) D. Fonirosa. Herbs, spikes many-flowered,

$\therefore . . \quad \therefore \quad \ldots \quad \ldots . . . \therefore(2)$ D: ALOPECUROIDES.

Sericeous, pubescent or tomentose.

Spikes very densềं; thick änd veryvillous

(3) D. NANA

Spikes rather lax; corolla pa purple, (4) D. LANATA Calyx pribescent or canescent, with short teeth, shirub

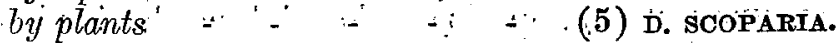

D. Formosa, Torr. Much branched; leaflets about 5 pairs, very small, about 1-6 inch long, thick and very narrow, cuneate "oblong, retuse; spikes loose, 6 to 10 flowered on short pediuncles; bracts ovate, shorter than the flower, silky villous on the märgin; calyx teeth plumose; corolla large and showy, bright purple. $A$ ' 
plant of the mesa seems to belong here but mine have a yellow stadard.

D. Alopectromes, Witd. Annuals, erect and much. branched, 1 to 2 foot high; beaflets 10 to 20 pairs linearoblong; flowers light rose color or whitish, in cylindrical spikes which are dense; bracts ovate-lanceolate, acuminate, deciduous; calyx with long slender teeth. University Campus. Sept. '07.

D. NaNA, Torr. 4 to 6 inches high, diffusely spreading and repeatedly branched, leafy to the spikes; leaflets 2 to 4 pairs, rarely pinnately 3 -foliate, oblong or obovaté; flowers yellow. Sand Hills.

D. Lanata, Spreng. Decumbent and the whole plant clothed with a soft almost wooly pubescence; leaflets 4 to 6 pairs, obovate-cuneate, emarginate, 1-2 in. long or less; spikes elongated, rather loose, many flowered, on rather long peduncles; bracts ovate with a long acumination; calyx teeth subulate plumose, dilated at base, as long as the tube. On the terrace mesa in the small arroyos.

D. Scoparia, Gray. "A broom-like plant with rigid slender branching, stems, naked below and roughened all over with large pustulate glands," the branches terminated by small globular heads of deep violet flowers; leaves mostly simple and linear, the lower ones with 3 linear leaflets. . Along the arroyas. 'Terrace Mesa.

8. Petalostemon, $M x$. Prairie Clover.

Perennial upright herbs, with minute stipules, small flowers in very dense terminal and peduncled heads or spikes. In otirs the plants are glabrous.

Corotla white,

Leaflets 7 or 9 , spikes oblong. when young, .....P. Candidus,

Leaflets 5 or 7, spikes cylindrical,

P. MACROSTACHYUS.

P. MTACROSTACH - P. PURPUREÚs.

P. Macrostachyos, Torr. Leaflets lanceolate-obor linear-oblong, sparingly dotted beneath; heads oblong, cylindrical when old, bracts awned, longer than the nearly glabrous calyx. On mesa and valley.

P. Macrostachyus, Torr. Leaflets lanceolate-oblong, obtuse, dotted beneath; bracts as long as the flowers, . calyx silky villous. Near Barelas bridge. July and August.
P. Aligophrluts, collected by Pres. C. L. Herrick in Tijeras Canon in July 'O8. Seems to be similar to $P$. Candidus but leaflets 5 to 7 . Very similar to the last also but the calyx seemis to be glabrous. My $P$. Macrostachus may belong here.

P. Purpureous, has short, crowded, oblong head. “Sandia Mts." June 1898. C. S. Herrick.

\section{Robinia, L. Locust.}

Trees or shrubs with prickly spines for stipules, the ovate or oblong leaflets stipellate, showy flowers in $a$ large axillary raceme, and a flat thin pod margied on one edge. The Eastern Locust ( $R$. Psendacacia) with white flowers and the Clammy Locust ( $R$. viscosa). with pale rose-colored flowers are commonlv planted.

R. Neo-Mricana, Gray. Shrub 4 to 10 feet high; peduncles and short crowded racemes hispid with straight gladiferous hairs; calyx finely hispid; corolla rose-color. Especially in the Quercus undulata jamesii Soc. of the Sandia Mits. but adso lower down where it is much taller.

10. Oxytropis, $D$. Mountain Loco.

O. Lamberti, Pursh. Silky with fine appressed hairs; leaflets mostly linear, flowers rather large, purple, violet or sometimes white; pod firm in texture, silky erect, lanceolate or cylindraceous and long pointed, almost 2-celled by intrusian of the ventral suture. On the prairies of Rim-Rock.

11. Astragulus, Toum. Milk Vetch. Loco.

Pods with oneor both sutures turned in, sometimes dividing the cell into two leigthwise. A large and difficult genus. Mature pods should be secured before indentification is attempted in most species.

*Pod turgid, at least partly 2-celled by the infolding of the dorsal suture the ventral being not at all or less deeply inflexed.

Pod plumb-shaped, succulent, thick and fleshy

Pod dry, coriacous, cartilaginous, Completely' 2-celled, sessile.

Ovate or globose, plant glabrous
' - (-2) a. piphysus.

Narrowly oblong; densely silky

Not completely 2-celled.

(3) A. Mollissimus. 

- 1 in. long. Cream color, bluish at tip; calyx softly hairy; pod globular, very obtuse and pointless, 1 in. or more in diameter, indehiscent;, sessile, completely 2-celled: Meśa. Not common:

2. A. diphysus; Gray. (Mottled A:). Nearly: globrous thruout; leaflets 6 to 11 pairs, obvate or oblong; flowers blue or purple; pod curved; frequéntly, mottled: (in all ours). Common on the mesa.

3. A. Mollissimus, Torr. ' (Loco.) Stout decumbent, densely silky thruout;; leaflets 19 ; or 20 , "ovateoblong. Violet flowers 1-2sto 1 in. long; pod, 1-2 to 3-4 in. glabrous; very common on the mesa especially "Terrace Heights.":

4. A. Scopulorum, Porter. Pubescent, calyx gib: bous at base, pilose with blackish hairs, corolla yellow or ochroleucous ; pod oblong, arching with age, stout, sharply. three angled; - dorsal suture reaching- the middle. Stem erect, stout, very leafý. Ai speciès of Tieras. Canon aparently bélongs here:

5: T. Mussouriensis, Nutt. Short-stemmed; hairy; leaflets 5 to 15 oblong; flowers few, $2=5$ tó 3 -5:in. long; calyx oblong, teeth very slender; pod oblong; 1 in. long.

6. A: TRIFLoRus, "Gray." "Low, very much branched from base; gray; leaflets linear or oblong; flowers few whitish or yellowish; tinged with purple; small pod, oval, 1-2 to 1 in: lóng.

12. Glycyrrhiza, Tourn. (Liquorice): Perennial plants with long sweet roots, glandulär visçid therbage, minute stipules, white flowers in axillary spikes.

G. LEPIDOTA, Nutt. (Wild Liquorice.). . Tall 2 to 3 feet; leaflets: 15 . to $19 \%$ oblong lanceolate, mucrenatepointed; pod resembles a cocklebur but smaller.

13. VICTA, Tourn:: (Vetch, Tare):

Climbing herbs with half sagittate stipules; $;$ axillary flowers on peduncles, a flat, several-seeded pod.

V. AmericaN.A; Muhl. A rather stout perenial, 1-4 ft. high, glabrous; leaflets 4 to 8. pairs... Einear to ovate-oblong; peduncles 4 to 8 flowered; flowers purplish; pod oblong, 3 to 6 seeded. Quite common near

the tops of the Sandia..Mts. among the rocks. 14. Tatrirus, Tourn. Vetehling. Everlasting, Pea L. Palúster, L. Slender, glabrous or somewhat L. PaLd; stem often winged; leaflets 4 to 8 , narrowly pubescent linear, semi-sagittate stipules with lanceolate oblong to luncles 2 to, 6 -flowered, flowers 1-2 in. long.

Var: Mratifotius, Gray Stipules broader and larger, leaflets ovate to oblong; 1 in. or less long . (or shorter). Among the shrub oaks of the higher slopes of the Sandia Mts.

15. Cassia, L Senna.

Herbs or shrubs with mostly yellow flowers, a parted calyx, 5 to 10 stamens with anthers dehiscing at the apex, and terete or flattened thick-coriaceous to membraneous manýseeded usually curved pods.

C. Bankiniomes, Gray. (2-leaved C.): Suffruticose and canescent; stmes 3 to 12 in. high, from thick woody root; 1 pair of leaflets (rarely: 2 ), oblong or subovate, rounded at bothe nds; peduncles 2 or : 3 flowered, equalling the leaf; pod turgid, 8 to 15 sseeded 1 in. long. "Highland" Parks" on the edge of mesa.

16.. Hoffmanseáge; Cav.

Low perennial herbs or woody at base; naked racemes of yellow flowers opposite the leaves or terminal; a flat oblong often falcate, few to several-seded pod. Leaves with black glands.

4 to 5 pairs of leafletsrto each pinnae,

- $\quad-\quad$ - $\quad$ - $\quad$ - H. BRACHYCARPA.

5 to 9 pairs of leaflets to each pinnae; 'H. JaMEsIr. Leaves destitute of black glands.

Pod broadly falcate, very. acute, 4 to 6 seeded H. OXYCARPA.

Pod broadly linear, rounded at base and apex 9

to 12 seeded, " - - $\quad$ H. DREPANOOARPA:

H. J AMESII. $T$ and $G$ : Herbaceous, and finely pubescent, pinnae 2 or 3 pairs: and an odd one, leaflets, small and oblong; pod broad, 1 in long, 2 or 3 -seeded. Mesa near Tijeras Canon.

H. BRACHYCARPa, Gray: Stems ascending from a lignescent root, slender, leafy to the top ;-pinnae 2 pairs and an odd one, leaflets ellipitical; pod oval:2-seeded, 2-3 to 3-4 in. long and 1-3 to 1-2 in. wide: Mesa, April and May.

H. oxycarpa. Low and slender from a woody base, villous pubescent; pinnae 3 to 5 pairs; and an odd one 
leaflets oblong, petals very short, stipitate; pod 1 in: long or more, 1-4 to 1-3 in. wide. Mesa, common. April and on.

H. DREPANOCARPA, Grioy. Low with many short (1 to 2 in.) slender stems rising from a thick woody root and terminating in a peduncle 6 in. long, 4 to 10 pairs of leaflets, about 1-4 in. long. Otherwise as last. "Allbuquerque 7-26, 1898." (Weinzirl).

42. ROSACEAE. Rose Family.

Herbs, shrubs, or trees, with alternate mostly stipulate leaves, regular flowers, mostly numerous stamens inserted on the calyx and one to many pistils, distinct and free or coherent with each other and the calyx tube.

${ }^{\prime}$. Ovary superior and not inclosed in the calyx tube at maturity.

*Calyx deciduous without bractlets; pistit solitary, becoming a drupe.

Tube 1. Prunear. Trees or shrubs with mostly serrate leaves, 2 ovules but usually a solitary seed and a terminal style.

1. Flowers perfect; lobes of calyx and corolla. 5; stone of drupe bony,

(1) PRUNU: **alyx mostly persistent ; few too many (rarely solitary) pistils.

OCalyx without braclets; ovules 2 tơ many

TRIBE II. SPIRAEEAE. Shrubs or perennial herbs, with mostly 5 pistills which become 2 to several seeded pods.

2. Usually erect and more or less diffuse shrubs 'with serrate or lobed corymbose or paniculate inflorescence and a 1 to several-seeded pod, which may be very tardily dehisent

SPIRAEA.

3. Shrubs with palmately-lobed leaves, corymbose flowers and inflated membraneously dehiscent pods,

PHYSOCARPUS TrIBE III. Rubeae, Herbaceous or with biennial soft woody stems, with the several or numerous pistils becoming drupelets in fruit.

4. Pistils numerous, fleshy in fruit, crowded upon a spongy receptacle, - - - - ' - Calyx-lobes mostly with bractlets; ovule solitary.

Tribe iv. Potentillacaea. Herbs, shrubs or trees with few to many-ovuled pistils becoming dry achenes. A. Shrubs. Styles elongated and plumose in friti; calyx imbricated.
5. Leaves simple, entire or toothed; small flowers axillary and solitary; calyx tube-cylindrical; peetals none; carpels solitary, rarely 2 , - CERCocArus.

6. Leaves with linear lobes; showy flowers on long peduncles and some what panicled; calyx-tube turbinate; petals 5 ; carpels numerous, - $\because$ FALLUGIA.

B. Herbs; calyx bracteolate; carpels few: to many: stamens and achenes numerous, the latter. heaped on a dry receptacle.

7 . Petals yellow, rarely white, sessile; stamens usually 20 or more; leaves pinnate or digitate; leaflets toothed or cleft, not confluent, - - POTENTILLA:

C. As in (B) but the receptacle large fleshy and scarlet.

8. Carpels very numerous, style lateral, leaves 3 foliate,

III. Ovaries inferior or inclosed in the calyx tube.

Tribe v. Roseat. Prickly shrubs, with pinnate leaves; petals conspicuous; stamens numerous; pistils many, becoming bony achenes, and inclosed in the globose or urn-shaped calyx-tube which resembles a pome. 9.

Tribe vi. Pomeas. Trees or shrubs with stipules free from the petioles, carpels 2-5, inclosed in and coalescent with the fleshy or berry-like calyx, in fruit becoming a 2 to several-celled pome. Apple tribe.

10. Ovary 5-celled the cells 2-ovuled and 2-seeded but in fruit each divided into 2 by a partition from the back; styles · $3-5$,

\section{Prunus, Tourn. Cherry,}

P. DEMissa, Walpers. (Wild Cherry). An erect slender shrub, 2 to $12 \mathrm{ft}$. high; leaves ovate or oblong, apruptly. acuminate, mostly rounded and somewhat cordate at base, sharply serrate, usually more or less pubescent beneath; fruit purplish, black or red, sweet and edible but somewhat ästringent. Bear Canon.

\section{Spirea, L. Meadow-Sweet}

S. Discolor, Parsh, var. DUMOSA, Watson. A diffuse pubescent shrub, 1-3 ft. high; leaves usually small, ovate, cuneate into a short margined petiole, nearly smooth above, often white tomentose beneath, pinnatifidly toothed or lobed; panicle somewhat diffuse and tomentose. A handsome plant widely distributed in the mountains. 
3. Physodarpus, Maxim Ninebark.

P. MoNogyNa; A small "shrub; leavés ovate or cordate; 3-lobed and toothed beneath ; flowers on short pedicels in simple ümbel-like corymbs' ovariès densely tomentose and but 1 or 2 'Sandia Mts. high up.

4. :Rubus, Touirn, Brämblé, Blackkberry.

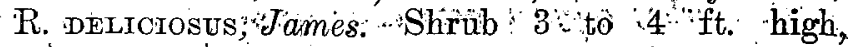
branches, young "leaves; and " calyz ${ }^{*}$ tomentose, not glandular, rugose, more or less 3 to 5 lobed; finely serrate tôothed leaves, réniform oriculär flowers 2 in. across; sepals with dilated acumination; petals white, fruit purplish, large smooth. "In spite of its name it is not good. Abundänt in placés among the Aspens of the Sandia Mts. Bear Canon.

"5." CERcocuRPüs," $H: B$ : $K$." (Mountain Mahoga-ny.) A shrub 2 to $10 \mathrm{ft}$ high or more.

O:" Parvifölur "Nuitt." - Leàves cuneate-obovate, co"riaceous, 'serrate towards the obtuse or rounded summit, 'morè or less silky aboìe', 'deńsely tómentosé beneath. Gommon on the lower slopes of the mountains in the El Ciandelabria änd Pinon Soèietiès.

6. Fallugia, Endl: Plumed Arroyo Shrub.

$\because$ A low shrub; flowers white, solitary?

F.PARADOXA,Endl. Mu'ch branched, 2 ft. high, with white persistent epidermis; leaves scattered or fassicled somewhat villous and thick 1-4 tó 4-5 in long, sessile, cuneate, pinneately' 3 to 7 cleft above; flowers few, an inch or more in diameter, the plumôse tail of the achene 1-2 in. long. "Very common in the arroyos of the mesa when it is usually the most conspicuous plant, easiily recognized by its plumose fruit. Also very common in the mounatins especially on the lower slopes.

7. Potentmllas, 'Ciñquéfoil. 5 Finger.

Herbs, often with a palmately 5-foliate leaves whence the name "Five Finger."

Style thickened and glandular towards the base

Style filiforim, not glandular at base.

Inflorecence cymose, leaves digitate '. P. GRACILIS.

Peduncles axillary, solitary, 1-flowered, leaves pinnate - - $-\quad-\quad$ P. ANSERINA, $L$.

P. Pennsýlivansca,' L. Silla-tormentose. 'Leares pinnate, leaflets 5 to 9 ; white tomentose beneath, short pubescent and greenish above, "the segments linear, stamens usually 25 . Ours seems to be Var. STrigosa,
Pursh, smaller; leaflets mostly tomentose on both urfaces, deeply pectinate divided or pinnatifid, with surfaces, margins! cyme short and close. Prairies of Rim-Rock. The leaves are almost bipinnate.

P. Gracilis, Dougl: (Graceful C.) Villous and more or less tomentose; stems 2 or 3 feet high; leafmore or ly seven, incisely serrate or pinnatifid, tomentose beneath, green above and subvillous or apmentose silky; carpels 40 or more, glabrous; style terpressal; conspicuous flower with t twenty stamens. Spruce-Acer-Robina Association of Bear Canon. July.

P. Anserina, L. Herbaceous Perennials. Greepmany-jointed runners, white-tomentose and silky villous leaves all radical, leaflets 7 to 21 with smaller villou interposed, sharply serrate, silky tomentose at ones interposed, sharply serrate, of the ovary. 'Carpels glabrous. Atrisco' and 'Hodgotite.

Fragaria, Tourn. Strawberry.

Flowers white, stamens many in one row.

F. Virginiana, Var.' Itimodinsis, Gray. Achenes imbedded in the deeply pitted receptacle in which respect it differs from $F$. Vesca, which many occur here. Bear Canon in the more mesophytic situations.

$$
\text { Rosa, Tourn. Rose. }
$$

Leaflets 7 ta 11, no infra-stipular spines, R.ARKANSANA. Leaflets 5 to 7 with infra-stipular spines, R. FENLERI.

R. Arkatsana, Porter.

Very prickly; sepals connivent and persisting after flowering as also in the next; stipules narrow; leaflets subcuneate at the base, simply toothed, not resinous; flowers corymbose; sepals not hispid, the outer lobed. Bear Canon.

R. Fendiert, Crepin. Stipules short and narrow; leaflets cuneate at base and usually glancous; flowers small, often solitary. Sandia Mountains.

Amelanchier, Medicus. June Berry. Service Berry.

Shrubs or small trees; leaves simple, serrate; flowers white, racemose; petals 5 , oblong; stamens 20 , short, fruit purplish, edible, looks like a small apple.

A. Amnifolia, Nutt. (Alder-Leaved J.) 3 to 8 feet high, glabrous or wooly-pubescent, leaves broadly ovate. or rounded, occasionally oblong-ovate, often somewhat cordate at base, serrate usually, only toward

(69) 
summit; petals narrowly oblong. Bear Canon, among the spruees.

43. SAXIFRAGACEAE, (saxifrage FaMily.)

Herbs or shrubs of various aspect, distinguished from the Rosaceae by having opposite as well as alternate le aves, usually no stipules, the stamens usually definate, and the carpels commonly fewer than the sepals.

Tribe I. Saxifrageat. Herbs with alternate leaves, distinct styles or carpel-tips, and a dry capsular fruit 1. Ovary with two or more cells, stamens 10 ,

\section{Ovary 1-celled, stamens 5, _ _ (2) SAXIFRAGA.} HEUCHERA. leaves and a 2 or 5-celled capsuular fruit.

Stamens 20 or more; ovary inferior,

(3) PHILADELPHUS.

Stamens 8 or 10 , ovary supe rior or nearly so.

(4.) Ovary 1-celled, petals, 5, - - JAMEsia

(5.) Ovary 4-celled, petals 4, - GENDLERA.

Tribe IIr. Ribesieat. 'Shrubs with alternate sumple leaves and fruit a berry; calyx tube adnate to the 1-celled ovary.

SAXifraga, $L$. Saxifrage

Calyx 5-lobed or parted, in ours united to the lower part of the ovary. Pe tals 5 entire. Petioles commonly sheathing at base. 'Small flowers.

S. BRoNChialis, $L$ : Stem spender, producing branchlets; leaves linear rather coriaceous, finely ciliate, mucronate-pointed, crowded below; flowers corybbose on a long slender bracted peduncle; petals white or cream color marked with numlerous purplish spots. Fir-Aspen Ass., at the head of Pinon Canon, Sandia Mountains: Looks like a Stellaria superficially.

2. HeUCHERA, L. Alum-root.

5-cleft calyx bell-shaped. Perennials, with the round heart-shaped leaves principally from the rootstock, petioles with dilated margins or adherent stipules at their base; greenish or purplish flowers in small clusters in a long narrow panicle! petals small, entire.

H. Parvifolia, Nutt. Scabrous. Puberulent; scape naked, 6 in. to 2 feet high; leaves roundish cordate, crenately 5 to 7 lobed; petals minute cadaceous; common in the Spruce Soc. of Bear Canon and in other mesophytic situations. May.
Philadelphicus, $L$. Syringa. Mock Orange.

Calyx limb 4-parted. Petals rounded or obovate, Jarge. Styles 3-5 united to the apex in ours.

P. microphyllus, Gray. (Small-flowered. S.) Branches slender, erect; leaves small, 1-2 to 3-4 in long, entire, ovate-lanceolate or oblong, shining above, and ninutely hairy beneath, narrowed at base into a very short petiole. Calyx glabrous without, tomentose within. A pretty plant with the showy white flowers (1-3) terminal. Pinon Soc. of Sandia Mountains. June and Jùly.

\section{JaMesta, $T$ and $G$}

Petals obovate, alternate stamens shorter, filaments linear. Low, diffusely branching, 2 to 7 feet high, leaves ovate, mucronately serrate; canescent beneath as well as the petioles, calyx, and branchlets; flowers cymose in terminal panicles.

$J$. Americara; $T$ and $G$. Cymes often longer than the leaves, 5 to 10 flowered; petals white, glabrous or softly hairy within; calyx-lobes shorter than the petals, enlarged and foliaceous in truit. Spruce-Aspen Soc. of Barrel-Spring, branch of Bear Canon. July.

\section{Fendlera, Eng. and Gray.}

Calyx-tube half adherent to the orary, S-ribbed; , tials ovate-deltoid, unguiculate emarginate; stumens 8 ; filaments 2-foiked at apex; seeds wunged below.

F. Ropicola, Eng. and Gray. Pulescent or Glab. rate, branches terrate, striate, leaves deciduous subsessile, oblong, very entire, 3-nerved at base; flowers $1-3$, terminal on short branches, peduncled, white. Bear Canon. May.

\section{Ribes; $L$. Currant Gooseberry.}

Calyx 5-lobed, often colored. Petals 5, small. Berry crowned with the shrivelled remains of the calyx.

Thorny and often prickly, GOOSEBERRIES.

Peduncles long and drooping,. - - R. Divaricata. ..Peduncles very short, - - R. OXYACANTHOIDES. Thornless and prickless, CURRANTS, - R.CEREUM.

Gooseberries. Ours have greenish-white or dull purplish calyx and a pleasant unarmed berry; are nearly gblabrous, thorns single or triple, lobes of the leaves incisely-toothed.

R. Divaricatum, Var. IRrigudm, Gray. Stems 5 to $12 \mathrm{ft}$, high, widely branching so as to form a large bush; leaves nervose-veiny at base, 3 to 5 lobed; pedun- 
cles 2 to 4 flowered; calyx lurid purple or greenishi white; petals fan-shaped, white; berry, dark purple. The common gooseberry of the Quercus Gambelii Soc. of the Sandia Mountains. Ripe in July and August.

R. Oxyacanthomdes, $L .2$ to 4 feet high; leaves usually deeply 5-lobed peduncles 2 or 3 flowered, calyx greenish-white or flesh colored; stamens and 2-cleft. style scarcely longer than ealyx; berry small, purple. At the Big Bend in Tijeras Canon.

R. Cereum, Dougl. Minuetely pubescent, usually resinous dotted and glutinous, leaves rounded or reniform, obscurely or well 3-lobed, crenately toothed or. incised; racemes drooping; pedicles hardly any or shorter than the bract; calyx wax-white, berry reddish, sweetish. On the highest Volcano. May and June.

44. CRASSULACEAE, Orpine Family.

Succulent or fleshy and mostly herbaceous plants. SEDUM, L. (Stone-crop.

Fleshy leaves, cymose and often secund flowers, 4 or 5 sepals and petals, and twice as many stamens.

S. WRIGHTIr. Gray stems diffusely branching, leaves few, ovate, 1-3 to 1-4 in. long; flowers very short pedicelled in a very compact, compound cyme; petals white, tinged with rose. Bear Canon.

45. OLAPPARIDEAE. CaPer Familx.

Herbs wit halternate leaves and perfect flowers much like Cruciferae but stamens more numerous, pod 1celled with two parietal placentae and kidney-shaped seeds.

Stamens $6 . . . . . .$. ... Cleome

Stamens 8 to $32 \ldots$. . Plolanisia. Cleome, $L$. "Bee Plant."

Sepals often united at base, pod with a stalk and many seeds. Erect, often tall, branching; flowers in bracteate racemes; and pendant pods.

C. Sonorat, Gray. Glabrous, leafleets 3 linear; flowers purplish; pod turgid somewhat longer than the stipe which is much shorter than the pedicel. Not uncommon. Very abundant along trails' sume years (as 1907), scarce others (1908); probably depending upon the amount and distribution of the rainfall.

Polanisia, Raf.

Fetid annuals with glandular or clammy hairs; petioled, mostly 3-foliate leaves with lanceolate leafletes; rose-colored or white flowers in leafy-bracted racemes.
P.uniglandulosa, $D c$. Peetals an inch long; long style, and smooth seeds.

46. ' CRUCIFERAE." (Mústard Famitì.)

Herbs with pungent watery juice, alternate leaves without stipules, flowers mostly bractless, in terminal racemes or corymbs; 4 sepals and petals, and a long or short pod. The mature pod must be obtained in order to identify'a plant.

1. Pod 2-CELLED, DEHISCENT By 2 VALIES. *Pod terete, turgid or 4-angied.

Pod long-linear (1 to 4 in.) seeds in 1 row.

Valyes 1-nerved, flowers, white or rose-color, - $\quad$ - - - - - (1) THELYPODIUM. Valves 2-nerved, flowers yellow, in ours, (2) SYSYMBRIUM. Pod oblong-cylindrical to globose, nerveless, seeds in 2 rows.

Pod oblong or short-linear, (3) NastURTIUM. Pod globose, - - (4) LESQUERELLA. **Pod flattened parallel to the broad partition.

Pod shorit, valves nerveless or faintly 1-nerved,

Pod elongated 1-nerved - - (5) DRABa. * Pod more or (6) ARABIS. ** Pod more or less flattened contrary to the narrow partition, flowers white.

Pod many-seeded,

- (7) CAPSELla.

11. Pod of 2 - (8) LePIDIUM. 11. Pod of 2 indehiscent cells, separating at maturity from the persistent axis, - - (9) BISCUTELLA.

THeLípodium, Endl,

Stout and coarse biennials with white or rosecolored flowers; sagittate, curved anthers; ours are glabrous. or nearly so.

Leaves all e ntire, - = T. LINEARFOLIUM.

Leaves all pinnatifid, ' - . - '. 'T. WRIGHTII.

T.IINEARIFolium, Watson. 1 foot high or more; leaves linear, the lowest lanceolate, acutish, sessile, 1 1-2 to 2 inches long. Flowers showy, 1-2 inch or less long, rose-purple; pods erect, very slender, 2 inches long. Barrel Spring branch of Bear Canon.

T. wrightir, Gray. 2 to 3 feet high; leaves broadly lanceolate, repand-toothed; pod becoming two or three inches long, with a very short stipe. , Sandia Mts.; especially on the tops RimtRock. 
2. Sisymbrium, Tourn.

Pubescent annuals or biennials with toothed or finely dissected leaves, very small yellow flowered (in ours), and oblong seeds.

S. Canescens, Nutt. Tansy Mustard. Leaves twice pinnatifid, often hoary or downy, the divisions small and toothed; pods in long racemes. Common about Albuquerque. March and May.

3. Nasturtium, $R . B R$. Water-Cress.

Aquatic or marsh plants usually glabrous with pinnatifid leaves (in ours).

N: Officinate, R. BR. European Water C.'

Le aflets three to eleven, roundish or oblong, nearly entire petals white, twice the length of the calyx; pods 1-2 to 1-3 inches long on slender, widely spreading pedicles. Common in the stream of Tijeras Canon especially toward the upper end.

\section{LAsoderelia, Watson.}

Low herbs, hoary with stellate hairs, yellow flowers, pods with a hyaline septum, nerved from apex to the middle. In ours the leaves are not auriculate clasping, filaments are filiform, seeds marginless, pods glabrous. with a very short stipe, erect on spreading or ascending pedicels.

L. engelemanni, Watson. Densely pubescent, caudex usually unbranched; leaves petioled, ovate to linearspatulate; racenie short; pods 1-4 inch broad. Very common in the mountains in the spring especially in the Pinon Soc. There are probably other species.

\section{Draba, Dill. (Whitlow-Grass.)}

Low herbs with stellate pubescence, entire or toothed. leaves; small white flowers. Ours are winter annuals, with short leafy stems.

D. cuneifolia, Nutt. (Wedged-leaved W.) Leaves cuneate-ovate to lanceolate, coarsely few-toothed or en tire; pods with short appressed hairs. Bear Canon in the Quercus gambelii Soc., early spring.

6. Arabis, $L$. (Rock Cress.)

Low or tall herbs with white or purple flowers, with perpendicular roots, and undivided leaves, the cauline usually clasping, auricled at base.

A. Spatrulta, Nrutt. (?) Hirsute, dwarf and somewhat cespitose, about 4 in. high; root thick; leaves spatvlate-oblong, entire, radical with the long petioles; petals about twice the length. of the sepals; pedicle about half as long as the pod which is rather short, diverging, pointed with a slender style; seeds with a narrow margin. Tijeras Canon.

7. Capselia, Medic. (Shepherd's Purse.)

Smooth or pubescent annuals with toothed or pinnatifid leaves and short obcordate pods.

C.Bursa-Pastoris, Meonch. Radical leaves mostly runcinate-pinnatifid, Cauline lanceolate and auricled at base. Introduced from Europe. About yards in town, not common as in the East.

$$
\text { 8. L.epinium. Pepper Grass. }
$$

Annuals or biennals with pinnatifid or toothed or entire leaves, tapering at the base. Pods rounded, 2winged at summit so as to appear notched.

L. montanum, Nutt. Mountain P.

Decumbent, many branches from a long somewhat woody root spreading in a circular manner; radical leaves more or less pinnatifid, upper trifid or entire; pods indistinctly reticulated, elliptical slightly emarginate, wingless, with a conspicuous style. Sandia Mountains, Rim-Rock towards the southward. Habit of growth much like an Arabis.

L. Eastrwoodiae, Wooton. Has no compound leaves but most of them are very sharply cut into long lobes, from oblanceolate to oblong-linear in outline; lower 2 in. long, petioled, upper entire small and sessile. Sandia Mts.

9. Biscutelca, L. (Spectacle Pod.)

Erect, hispid or tomentose, branching herbs; valves or pods nearly orbicular.

B. Wrstrzeni, Watson. Leaves ovate-lanceolate, tapering into short petioles; repand, dentate; pedicles filiform 1-2 to 2-3 in. long, longer than the flower or fruit; flower about 1-4 in. in diameter; pods 1-2 in. or less in width and about as high, deeply cordate at base. Not rare along the edge of the mesa and in sandy places in the valley.

47. FUMARIACEAE, FUMITORY Familt.

Delicate smooth herbs; with compound dissected leaves; irregular flowers, two small scale-like sepals; four petals in two pairs, the outer with spreading tips, and one or both spurred or saccate base, the inner with crested tips united over the stigma; 6 stamens in 2 sets of, 3 each; 1-celled few to many-seeded pods. The "Dutchman's Breeches" of the east and the "Bleed- 
ing Heart." of the gardens belong here.

$$
\text { Clordalis, Vent. }
$$

Ours have yellow flowers in racemes, corolla onespurred atthe base.

Spur of the corolla barely half the length of the

body, - - - - - c. AUREA.

Spur as long as the body of the petal,

- $\quad-\quad$ - - c. CURVISILIQUa.

C. Aurea, Will D. (Golden C.) Slender with spreading pedicels, spur somewhat secund, . terete, twisted when dry. Ours belong to the Var occIDENTaLs, Engelm. Is more erect and stouter, with larger flowers, and the spur almost as long as the body, and commonly ascending; pods less twisted, mostly incurved. Sandia Mts.

C. Curvisiliqua, Engeln. Like the preceding but flowers rather larger; pods quadrangular. Sandia Mts.

48. BERBERIDEAE. (Barberry FAMILY.

Shrubs (ours), with sepals and petals usually in two rows of three each, alternate leaves.

Berberis, L. (Barberry).

Wood and flowers yellow; 1 to 9 foliate leaves; flowers in drooping racemes; a pair of glands on the base of each of the 6 sepals; stamens will close up towards the pistol if touched; fruit a berry with one or few seeds.

Low, racemes rather open, - - -

3 to $6 \mathrm{ft}$, tall, racemes dense, - - в. FENDLERI. B. NANa. A low evergreen shrub, less than $1 \mathrm{ft}$. high; 3to 7 leaflets, ovate acute, they look like those of a holly only larger. Common especially in the SpruceAcer Soc. of the Sandia Mts.

B. Fendleni, Gray. (Tall Barberry.) Branches smooth and shinning "as if vamished." Calyx with conspicuous red bracts. Bear Clanon below the $7000 \mathrm{ft}$. level. Not as common as the last.

49. RANUNCULACEAE. Cirowfoot $F_{\text {ammly. }}$

Herbs, sometimes woody; with few or numerous sepals, petals stamens and pistols (sometimes apetalous) all distinct and free, sepals often petal-like; fruit an akene, pód or berry; leaves simple or much compounded, petioles dilated at base.

Petals broad and conspicuous, seed erect in the achenes, -- - - - - (1) RaNunculus. Petals none, small, or irregular or spurred; seed horizontal.
Truit ackenes, collected in heads.

Half-woody, leaves opposite, - - (2) clematis.

Herbs, leaves opposite or whorled, (3) anEMoNe.

Herbs, leaves alternate; - - (4). tiraliorrum.

Truit a pod (1-5) leáves alternate.

Flowers regular,

(5) AQUILEGTa.

Flowers irregular,

-(6)' DELPHINIUM.

Frut a berry of one carpel; $\quad-\quad$ - (7) aCtaEA.

1. Ravúvicutus. (Crowfoot.)

Annual or pérennial plants with alternate stem leaves; solitary or corymbed yellow or rarely white flowers; petals with a pit or scale at the base inside; fruit a head of achenes.

Aqutics, petals white, - - $\quad$ R. AQUATILIS. I. I'errestial, petals yellow...

Leaves crenate only, - - - - R. crmbaldia. Some or all leaves cleft or divided

- . - - - - R. RHombotDeus.

R. Aquatilis, L. Var. trichophýllus. Chaix. (White Water C.) Leaves all-submersed and cut into numerous fine segments which collapse out of water; the claw of the petals yellow; achens in a close head, transversely wrinkled. In the valley.

r. CYMbayabia, Pursh. Radical leaves undivided, broadly oval only clustered at the roots and at the nodes of the long rooting runners, glabrous perennials, stemleaves none; petals longer than the green sepals, heads oblong. Atrisco and other places in the valley. In $\mathrm{Ti}^{-}$ jeras Canon.

R. RHOMBoIdeUs, Goldie. 'Dwarf, 3 to 6 inches high, lairy; root-leaves roundish. crenate, lowest stcm-leaves similar or 3 or 5 -lobed, the upper 3 to 5 -parted; petals large, exceeding the calyx. Bear Canon.

2. " Gilematis; $: \dot{L}$. (Virgin's Bower.),

D.pennial herbs or vines climbing by the leaf sinck, 4 c. iured valvate sepals; " "rials; num achenes with the persistent styles forming tails in the fruit.

C. 'Alpina, Mills, Var. occidentalis, Gray. Trailing, nearly glabrous, leaves bilaterally divided, segments orate or oblong, lanceolate, acuminate, frequentry the ce-lobed, irregulan'y 'orehed; sep to purplishblue, thin; some of the conter filaments enlarging to small petals, linear achenes glabrous.: Spruce-AcerRobinia Soc. in Sandia Mts. r.May. 


\section{WATSON Plants of Bernalillo County}

3. Anemone, $L$. (Wind-Flower.)

Sepals colored and petal-like; perennial herbs with radiral leaves, those of the stom opposite or whorled and forming an involucre remote from the apetalous solitary (in ours) flower; achenes flattened, but not ribbed, and (-in ours) with long bearded tails.

a. Patens Var. nuttalliata, Gray. (Pasque-flower)

Villous with long hairs; flowers erect, developed before the ternately divided leaves, large; sepals 5 to 7 purplish; a beautiful and striking plant growing ửndex the Yellow Pines high up on the Sandia Mts. $(8000$ ft anci over) in early spring. Sometinats protruding through the snow.

4. THALICTRUM, TOUm. (MEADOW RUE:)

Perennial herbs with panicled, dioecious flowers; 4 or 5 sepals; numerous tailless and ribbed achenes; and alternate ternately-de-compound leaves.

T. FENDLERI, Eng. Grandular or grandular-pubescent, erect, sometimes tall; leaflets remote small, round with three divergent lobes, the central or all again lobed; stamens numerous; achenes 10 or less. Sandia. Mts. in Quercus Gambelli Soc.

5. AQUILIGIA, Tourn. COLUMBINE.

Perennials herbs with ternately, compound leaves and lobed leafle ts, large and showy flowers terminating the branches, sepals and petals colored alike, petals with spurs much longer than the sepals, pord erect and many seeded.

a. Canadensis, $L$. Spur straight; flowers 2 in. long scarlet, yellow inside or rarely all over, nodding, with the spurs turned up. Sandia Mts.

6. DELPHINIUM, $L$. LARIKSPUR.

Sepals 5, petal-like; petals 2 or 4 ; pods many-seeded; erect herbs with palmjately parted leaves; flowers from blue to white, in racemes.

D. sCOPULORUM, Gray. Finely hoary or glabrous, leafy; leaves orbicular, 3 to 5 parted, the divisions deeply 2 or 3 cleft, the segments many-lobed or laciniate; spur longer than sepals; pods pubescent. In the Aspen Soc. of Rim Rock June and July.

$$
\text { 7. ACTOEA, } L \text {. BANEBERRY. }
$$

Perennials herbs with 2 or 3 ternately compound leaves; sepals 4 or 6 , petal-like. Petals 4 to 10 . Stigma sessile, 2-lobed. Seeds numerous in 2 rows.

A. spicata, $L$. Smooth, 1 to $2 \mathrm{ft}$. high. In the As- pen Soc. high up in Bear Canon. June and July. 50. CARYPHOYLLEAE. PINK FAMILY.

Herbs, with opposite, entire leaves; persistent calyx; 4 or 5 petals; usually twice as many distinct stamens; 4 or 5 , mostly distinct, styles; and seeds atached to the base or central axis of a 1-celled pod. In ours no thipules, and petals without claw or crown. Petals bifid.
1) STELIARIA. Petals entire or wanting, - - - (2) ARENARTA. 1. STELlaria, $L$. CHICKWEED.

Stamens ten or fewer, styles three, usually, capsule gwlobose to oblong, low spreading herbs, flowers white, solitary or cymose mostly 4-angled.

s. JAMESII, Torr. Bracts foliaceous; plant somewhat sticky, rather stout; leaves ovate-lanceolate to linear; seeds smooth. Fir-Spruce-Aspen Soc. , Bear Canon.

2. arenaria, $L$. Sandwort.

Leaves often (as in ours) subulate or rather rigid, always sessile. Ours belongs to Areraria Proper with the three valves of the capsule two eleft or parted; seeds not appendaged at the hilum; caespitose perennials.

A. FENDLERI. Stems numerous from a perennial caudex, glabrous below, more or less glandular-pubescent above; many crowded leaves at the base; leaves long; eymes strict, open-flowered, sepals acuminate with a broad scarious margin. Barrel Spring branch of Bear Canon. July, '08.

Look for. A. Sakosa with lanceolate leaves, more numerous flowers and the sepals with a "hispid, distinct almost keel-like midrib."

\section{FICOIDEAE.}

Chiefly fleshy or succulent plants with opposite leaves and no stipules. Ours are apetalous and with the calyx free from the ovary.

sesuvium; $L$. (Sea Purslane.)

Usually prostrate plants in saline soil, with axillary or terminal purplish flowers, persistent and free, five parted calyx, the lobes apiculate below the top, five to sixty stamens inserted on the calyx, three to five separate styles and a three to five-celled, miany seeded pod whose upper part falls off as a lid.'

S: portulacastrum, $L$ : (Purslane-like S.) Stems often one foot long or more; leaves linear or oblonglanceolate, two fifths to one and one-half inches long;

(79) 
the flowers solitary or clustered, sessile or pedicellate, calyx one-fourth to one-half an inch long,i the, lobes apiculate on the back and more or less purple. In alakli soil towards Isleta July and August.

52. PORTULAOEAE. PURSLANE: FAMILY.

Succulent herbs with entire leaves, two sepals, two to five or more petals, opposite stamens of ithe same number. or (in ours) numerous, - two to : eight cleft styles, and a one celled pod with a free central placenta, stipules none or scarious or reduced to hairs.

\section{Portulaca, Tourn. (Purslane.)}

Annuals with entire leaves, axillary yellow flowers, two sepals united at the base and with the ovary, the free upper portion at.length deciduous, four. to six petals, seven to twenty.stamens and:a deeply three to eight-eleft style; pods opening by a lid, le aves flat in ours.

P. Oleracea..... (Common P.). Prostrate, glabrous, purplish; stem terete, leaves obovate to spatulate, rounded at summit; sepals acute, keeled; petals one-eighth to one-sixth of an inch Iong; stigmas five; pod one-fourth to one-half of. an inch long; seeds black, dull, finely tuberculate. Occasionally about yards and gardens.

P. RETUSA; Englem: Like the last but greener.and the stems more ascending, sometimes covering a space several feet in diameter; leavẹs usually smaller, retuse or emarginate; sepals obtuse, broadly keel-kinged; petals yellow; stigmas three or four; capsule one-fifth to one-fourth of an inch long; seeds more strongly tuberculate. Sandy fields 'and aroyos at edge of mesa.

53. TAMARISCINEAE. Tamarisc-Family.

An Old World family of trees and shrubs to which belongs our, Tamarix, $L$. Tamarisc, often but wrongly called "Tamarack.".

Shrub or small tree with slender branches covered with small green scale-like leaves, and small flowers in termianal spikes or racemes. : ;

T. Gallica, L. Commonly planted on the campus and in the town as a hedge plant.

54. NYCTAGINEAE' (FOUR O'CLOCK FAMILY.)

Herbs with mostly opposite and entire leaves, stems swoolen at the joints, a delicate tubular or funnel-form corolla-like' calyx; with its persistent base constricted above the 1-celled 1-seeded ovary.
Involucre calyx-like of united-bractlets, 1 to 12 flowered.

Involucre 5-lobed, enlarged in fruits, 1 to 5 flow-

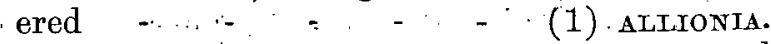

Involucre deeply 3-lobed, 3-flowered, not enlarged in fruit, - $\quad$ - $\quad-\cdot \quad$ - . (2) wEDELIA. Involucre of 5 or more distinct bracts, under a many.- flowreed head, ... - : (3) ABRoNia.

Involucre minute, 3 purplish bracts to each flower,

$$
\text { 1.: Allionia, Loefl. }
$$

(4) BoERHatia.

Herbs with very large thick perennial roots, opposite leaves, calyx with a-very short tube and bell-shaped (rose or purple) deciduous limb which is plaited in the bud; usually 3 stamens, filiform style and fruit usually several-ribbed or angled.

Fruit glabrous, involucre 3-flowered, 'А. оХуварноाDEs. Fruit pubescent, involucre 3 to 5-flowered,

- . . - _ - A. ANGUSTIFOLIA.

A. oxybaphoides, (Gray.) Kuntze. Stems slender, duffuse, procumbent; leaves all deeply cordate on rather long petioles, the lowest reniform; the upper acuminate. and sometimes subangulate; involucre and peduncles very viscid. Tijeras Canon.

A. angustifolia; Nutt. Often tall, glabrous -execept. the more or less hirsute peduncles and involucres; leaves linear thick and glabrous, often elongated, 2 to 6 in. long.

\section{WEDELIA, Loefl.}

Annual or perennial herbs, with opposite very unequal leaves; flowers on peduncles in the axils., usually three stamens; the ovate compressed fruit surrounded by a rigid winged margin, smooth and convx on the inner side and with a double line of tubercles on the back.

W. 'incarnata, $L$, Kuntze. Stems slender; branch. ing, prostrate; pubescence viscid, short' or woolly leaves ovate; lobes of involucre concave, acute. Common on the sandier parts of the mesa.

$$
\text { 3. Abronia, Juss. }
$$

Low, usually viscid plants, with thick petioled unequal leaves, peduncles bearing numerous showy and sessile. flowers in a solitary head: salverform calyx with limb of 5 segments, 5 unequal and included stamens adnate to the tube, and a coriaceous 
one or 2-winged fruit, inclosing a smooth cylindrical achene.

Fruit, coriaceous, not rigid,

A. FRAGRANS. Fruit more rigid or woody,

A. CYCLOPTERA.

A. Fragrans, Nutt. Root-perennial; stems ascending; leaves oblong or ovate; involucre bracts large, broadly ovate, white and scarous; flowers white; fruit not crested, the cavity extending through the entire wing. Common in the more sandy places on the mesa. Summer.

A. Cycloptera, Gray. Annual; flowers large-and showy upon long peduncles; fruit with wings completely encircling it, making the outline orbicular, membranaceous and prominently veined, the smooth body usually 3-nerved. On mesa. Not common, in summer.

4. Boerhavia, $L$.

Slender annual or perennial, diffuse or procumbent herbs, with more or less unequal leaves, usually very small flowers, a 5-lobed funnel-form or campanulate perianth, and a ribbed clavate or obovate fruit, jointed upon the pedicle.

B. WRIGHTI, Gray. Small-flowered 4-o'clock. Stems erect and slender from an annual root, loosely branched, branches viscid; leaves small oblong-obovate, undulate, black punctate, white below; peduncles paniculately spiked, bearing few flowers on very. short pedicles; bracts and bractlets minute, purplish, deciduous; calyx pale purplish; fruit barely one-eighth of an inch long, obovate, glabrous, wrinkled between the ribs. Mesa.

55. CHENOPODIACEAE. (Goose-Foot Family.

Chiefly herbs of homely aspect, more or less thick and fleshy, with mostly. alternate lèaves, stipules scari-. ous bracts or none, minute greenish flowers with a free persistent calyx, stamens as many as the calyx lobes and inserted opposite, two (rarely 3 to 5 ) styles or stigmas and a 1-celled ovary and a 1-seeded fruit.

With fleshy or at least thick leaves, or spiny.

Flowers perfect, herbs or shrubs.

Calyx wingless, leaves succulent, (1) Suakda. Calyx winged in fruit, leaves spiny,

$$
\text { (2) SALSOLA. }
$$

Flowers unisexual-calyx winged, shrub,

Leaves not fleshy, larger.
Calyx in fruit surrounded by a horizontal continuous membranaceous wing, (4) Crcloloma. Calyx unchanged or fleshy in fruit;

(5) Chenopodium.

1. Suacda, Forsk. Sea Blite.

Herbs or shrubs with subterete leaves, axillary, clustered, or solitary sessile flowers, calyx-lobes unappendaged (in ours), 5 stamens, 2 or 3 stigmas, and a black shining seed.

Herbaceous annual 12 to 16 inches high, .S. DIFFusa. Perennials with woody base, 2 to 5 ft. high, S. MoQdinI.

S. DifFusa, Watson. Erect 12 to 16 inches high, diffusely branching with usually slender flexous branches; leaves 1-2 to $1 \mathrm{in}$. long, acute or acuminate; floral 1 similar but shorter, usually rather distinct on the branchlets; clusters 2 to 4 -flowered; calyx cleft to below middle, fleshy but not keeled; seeds perfectly smooth, 1-25 of an in. in width. Towards Isleta, in alkiline fields. July and August.

S. Moquini, Torr: The herebaceous le afy branches smooth or tomentose; leaves as in the last; clusters several-flowered; calyx rather large; deeply cleft, seeds finely tuberculate 1-16 of an inch broad. Not widely distributed but found in twop laces in the valley (along the railroad 5 miles south of town and near Upper Alemeda) it forms a large society where it is almost the only plant. - Its branches kold the soil from being blown away and hummocks several feet.high result. Occasionally higher up the same arroyo to where the Bear Canyon trail crosses it.

\section{Salisola, $L$. Saltwort.}

Flowers with two bractlets. "Calyx 5-parted, persistent and inclosing the depressed fruit in its base; its divisions at length horizontally winged on the back, the wings forming a broad and circular scarious border. Stamens mostly 5, styles 2, seeds filled by the embryo which is coiled in a conical spiral, the flowers sessile and axillary.

S. Kalt, var. tragus. The Russian Thistle, "Tumble Weed." This spiny plant is too common around Albuquerque, especially on the western edge of the mesa and where the soil has been disturbed by grading or along trails. 
3. Sarcobatus, Nees. Greasewood.

A rigid and 'spre ading 'branched shrub,' with linear leaves, naked stamenite flowers in aments, axillary and solitary pistillate ones with saccate calyx which is adherent at the contracted somewhat 2-lipped apex to the. base of the stigmas, and margined on the side by a border which in fruit becomès a wing $; 2$ to 5 stamens a nd fleshy anthers.

S. Verimiculatus, Hook, Torr. Erect, subspinescent, scraggy, 2 to 8 feet high, leafy; branches with smooth white bark; staminate spikes terminal. Quite common on the foot hills of the mesa.

4. 'Crclóloma, Moq. Winged Pigweed.

Coarse and much-branched annual herb with alternate petioled 1 eaves, very small scattered sessile perfect or pistillate flowers in open panicles, 5-stamens, 3 (rairely:2) styles and flat seeds.

C. ARTRIPLicifolia, Spreng. Sorrel Leaved W. P.)

Diffuse; 6 to" 14 ' inches high, 'more or less webbyhaired, light green or often purple; leaves lanceolate, 1 to 2 inches long, coarsely-toothed. Sandy or alkali fields in the valley.

5. Chenopodium, L. (Goose-foot, Pig-weed.)

Annual weeds flowering in late summer and autumn, usually mealy or glandular, with perfect sessile flowers in small clusters collected in spiked panicles, 5parted calyx, 5 stamens'with filiform filaments, 2 styles, and lens-shaped seeds.

C. ALbUM, L. (Lamb's Quarters.) Erect 1 to $4 \mathrm{ft}$. high, mealy; I eaves from lanceolate to rhombic-ovate, acute, at least the lower angulate-toothed; clusters spiked panicled, mostly dense; calyx .06 or 1-6 inches broad in fruit with strongly keeled lobes, nearly or quite covering the fruit. A common weed in the East, accasionally"about Old Albuquerque gardens.

C. mybridum, L. ' (Maple-leaved Goose-foot.)

Bright green throughout; stems widely much branched 2 to 4 feet high ; leaves thin, 2 to 6 inches long, somewhat triangular and cordate; taper-pointed, sinuateangled, the angles extending into a few large and pointed teeth; racemes duffusely and loosely panicled; leafless; calyx not fully covering the fruit. its lobes keeled. Tijeras Canon.'

56. AMARANTHACEAE. (AMaranth Family.) Chiefly hèrbs with entire leaves destitute of stipules, small perfect or unisexual flowers usually subtended by scarious bracts and with a persistent calyx of one to five more or less scarious sepals. There are probably other genera within our limits but I have collected only these.

Axarantreus, $L$. Amarianth.

With thin alternate leaves; small greenish or pur plish flowers with 1 or 3 bracts in axillary or terminal spikes, like clusters, and 2-celled anthers (most of the genera have 1-celled anthers.)

Utical (pod) thin, with a lid at the top.

$$
\text { A. RETROFLEXES. }
$$$$
\text { Utrical bursting; leaves with spiny axils, }
$$
Utrical bursting; leaves with spiny axals,

A. spinosus.

A. RETroflexus, L. Rough more or less pubescent, erect 1 to 6 feet high, leaves dull green long petioled, ovate, undulate; flowers green in thick spikes crowded in a head-like panicle, petals and stamens .5; bracts pointed, rigid, longer than the acute or obtuse sepals.

A. spinosus, $L$. Thorny Amaranth.

Smooth, bushy; redish stem; leaves rhombic-ovate or.ovate-lanceolate, dull green, a pair of spines in the axils; flowers yellowish-green, monoecious. Yards about town, perhaps introduced.

57. POLYGONACEAE. (Buckwheat Family.

Herbaceous or woody plants, with alternate, e ntire, leaves; stipules form sheath about the swollen joints of the stem or are absent; mostly perfect flowers on jointed pedicels, a persistent 3 to 6 -cleft calyx; a 1celled ovary with 2 or 3 styles or stigmas and a single erect seed; 4 to 9 stamens; fruit an achene, compressed or 3 or 4 -angled.

Flowers with an involucre; stamens 9 ; stipules nont,

- $\quad$ - $\quad$ - $\quad$ - ' $\quad$ (1) ERIogonUm

Flowers without an involucre; stamens 4 to 8 ; stipules forming sheaths.

Sepals 5, equal and erect in fruit, achenes triangular or lenticular, - (2) Polygonum.

Sepals 6 , the outer row reflexed, the inner erect and enlarged in fruit, - - (3) Rumex.

1. Eriogonum, $M x$.

Herbaceous or a little woody, leaves radical alternate or verticillate; involucre bell-shaped with several exserted flowers, compressed of 4 to 8 pointless 


\section{WATSON - Plants of Bernalillo County}

Iobes or teeth; calyx 6-cleft, inclosing the 3 angled achene; 3 stigmas.

Involucre campanulate not nerved or angled.

Involucre 4 to S-toothed; bracts foliaceous,

Involucre 5-toothed, bracts not foliaceous,

E: TENELLUM

Involucre cylindrical, 5 to 6-nerved and often ribbed or angled in age,

E. WRIGHTII.

E. LACHNogYNUM, Torr. Cespitose and densely. tomentose; leaves all radical, oblong-lanceolate; the slender naked peduncles a foot high; involucres solitary, the bracts small, the flowers densely tomentose achenes densely villous. Tijeras Canon.'

E. TENELLUM, Torr. Tall, densely white-tomentose branches of the woody caudex short and crowded or elongated; leaves ovate or rounded tomentose on both sides; radical ; flowers white or pinkish, glabrous, outer sepals broadly obovate or orbicular, the inner linearoblong. Lower Sandia Mts.

E. Wrightil, Torr. Stems leafy, white tomentóse, much branched and slender; leaves oblong to linear lanceolate, acute, 1 inch or less long, white-tomentose beneath, bracts small, triangular; - involucre solitary. and sessile, loosely spicate along the ascending branches 1-12 to 1-8 inches long with rigid acute teeth; flowers white or rose color, the length of the bracts, glabrous; achene scabous above, acute at base. Sandia Mts. near the base.

\section{Polygonum, L. Knotweed.}

Herbs of late summer and autumn; flowers small and perfect in axillary or spicate racemose fascicles. Besides the one species collected there are undoubtedly others in the county.

P. aviculare, $L$. Pigmyweed.

Slender mostly prostrate or ascending bluish green plants. In the East it oftens forms a thick turf-like mat on the ground, but here are only a few scattering plants; leaves oblong to lanceolate; 1-4 inch to nearly an inch long; usually acute; sepals scarcely $1-25$ of an inch long; green with pinkish margins; stamens 8 . Along acequias, etc.

58. LORANTHACEAE. (Mistletioe Family.)

Shrubbery plants, with coriaceous, greenish foilage. Ours are parasitic on Cedars.

\section{Bulletin University of New Mexico-No. 49}

Prroradenron, Nutt. (False Mistletoe.) Yellowish-green dioecious, much branched, stems, fforming a thick bunch; berries semli-transparent.

P. JUNIPERINum, Engelm. Glabrous 6 to 10 inches high; branches round. The youngest pranchlets quad rangular; scales (leaves) broadly triangular, rather obiuse apex; berry, whitish or light red; $1-8$ of an in. in width. Common on Cedars in the mountains. Further south grows the American Mistletoe ( $P$. flavescens) with green foliaceous leaves.

59. SANTALiACEAE, (Sandat-wood Family.)

Herbs or a bit shrubby at base, mostly root parasites, with angled or straight branches; entire, alternate, sessile leaves, without stipules; perfect flowers with 3 to 5 cleft perianth adherent to the 1-celled 2. to 4-ovuled ovary, which becomes an indehiscent 1-seeded nut-like fruit; 3 to 5 stamens at the edge of disk which covers the ovary.

Comandra, Nutt. (Bastard Toad-flax.)

Low, herbaceous, smooth perennials, with subterranean roots-stocks; glaucous leaves, lowest scale like; greenish-white flowers in small umbellate clusters; calyx bell-shaped with a 5-lobed limb; stamens included.

C. umbelitate, Nutt. 6 to 12 inches high, branched; very leafy; leaves oblong, pale, 1 inch long. Calyx tube. forms a neck on the dry giobular urn-shaped fruit. This is apparently var. ANGUSTIFolis, with all the middle and upper leaves linear and acute. Sandia. Mts.

60. URTICACEAE. (Nettre Family.

Herbs, shrubs, or trees (ours small), with stipules, monoecious or dioecious or rarely perfect, flowers; calyx regular, free from the (usually 1-celled) ovary which forms a 1-seeded fruit; stamens as many as the calyx lobes or fewer and opposite them. The elms and commonly planted mulberry, the hedge plant 'Osage orange (thorny), and the hop vine belong here.

$$
\text { Ceittis, } L \text {. Hackberry. }
$$

A small tree with alternate, unequal sharply pinnate-veined serrate leaves with short petioles, stipules falling early; greenish axillary flowers.

C. Meticulata, Torr: (Reticulated. H.) Somewhat pubescent with short spreading hairs; leaves thick, very rough and strongly reticulated, 2 to 4 inches long, obliquely ovate-cordate at base, shortly acuminate, 


\section{WATSON- Plants of Bernalillo County}

fruit a 1-seeded globose drupe, 1-4 inch or more broad, on a slender stem; 4-10 of an inch or 5-10 of an inch long. Common along the lower parts of the streams flowing out of Bear Tijeras, Pinon, and probably other canons. The last trees as you descend these streams; are not usually over 15 feet high.

Look for C.Pallida, a shrub. 6-10 feet high with an orange-yellow colored fruit and for $\mathrm{C}$. occIDENTILIs, the common' hackberry of the East which is larger with a reddish or yellowish fruit which turns purple at maturity. Théy may occur here.

61. CUPDLIFERAE. OAK FAMILY.

Trees or shrubs with alternate simple straightveined leaves; decideous stipules; morroecious flowers, the sterile in catkins the fertile in solitary or small elusters.

\section{Quercus, $L$. (Oak.)}

Trees or shrubs, blossoming in April or May and maturing their acorns in autumn of the same year (in ours); or the following year. Our species are very confusing and others probably oeur.

Q.GAMBELIIS Engelm is the taller oak found in dense groves in the canons and growing to 20 feet or more high; nuts edible.

Q. INLULATE, var. JAMIESII, is the lower shrub oak with the smaller leaves, that covers most of the higher slopes of the mountains and Rim Rock. Tbis and the last are deciduous.

LIVE OAKS are evergreen shrubs with more or less spiny leaves which resemble those of the holly. Our species are difficult for a beginner, the species are Q. Grisea. Lick and Q. turbinata.

62. SALICINEAE. (WILLOW F FMILY.

Dioecious trees and shrubs, with both kinds of flowers without envelopes, (except a bract), and in catkins. Seeds with long down to catch the wind. Wood soft and light, bark bitter.

Bracts entire; stamens few, stigmas short, buds with single scale, - - - - - - - SAIIX Bracts lacerate, stamena numierous; stigma long, bud scaly;

\section{SaLIX, L. Willow.}

Too well known to need further description. Not common here.
Bulletin University of New Mexico-No. 49

S. Amygdaloides, Anders. (Peach-leaved Willow.)

Leàves lanceolate, 2 to 4 inches long; with a long slender point, pale beneath, on slender petioles closely serrate with teeth bent in. Stipules deciduous early. Sand dunes to oward Isleta.

S. NigRA, Marsh. (Black W.). Leaves narrowly lanceolate with very long curved tip; stipules large and persistent. Near streams of water in the Sandia Mts.

S. LONGIFOLIA, Long-leaved $\mathrm{W}$.)

Leaves linear-lanceolate, 3 to 4 in. long and 1-12 to 1-2 in. broad, tapering at each end, (as neither of the preceding spécies do.) Stipuless small, decidious. The leaves have only a few teeth which project. Along the Rio Grande among the cotton woods.

Populus, L. (Poplar, Aspen.)

Besides our three native species the following are planted in the valley; the tall-tapering (conical-shaped) Lombarda Poplar from Europe is often planted along drives and the Silver Poplar with leaves very bright green' but silvery beneath. S.'E. of the Dining Hall, on the Campus and places in the valley. Spreads from roots.

P. Balsamifera, $L$, and its var candicans. (Balsam P. Balm of Gilead), with very large sticky buds, heart shaped leaves, serrate, whitish beneath, 1-2 to 2 in. long. $A$ fine tree of this species overhangs the east end of the viaduct over the railroad on Iron Ave.

P.monilifera, Art. The Cototn-wood of the East with broadly deltoid le aves is occasionally planted. Leaves broad, cordate.

Pod large, grows along the Rio Grande,

- - P. FRemont

Pod small, grows high up in the Canons of. Mts.

- - - - P. TREMULOIDES. Leaves ovate-lanceolate, grows low down in the Canons,

- - - - Pl ANGUSTIFolia P. FREMonti Watson, Var (?) Wislizeni. (Valley Cotton-wood.) A good sized tree with cracked bark; leaves broadly deltoid or somewhat kidney shaped, broader than long with acuminate apex, 4 to 12 teeth on each side, petioles 1 to 3 in. long. Pod 1-3 to 1-2 in. long. Composes the for ests along the Rio Grande and is, common along the acequias and other places in the valley, and commonly planted.

P. TREmuloIdes, $M x$. (American Aspen, Quaking (89) 
Asp.) A small slim tree 20 to 50 feet high but seldom over a foot thick, with smooth greenish-white bark; leaves roundish-cordate, with a sharp point and small somewhat regular teeth, smooth on both sides, with downy margins on very slender petioles which cause them to vibrate in the wind. In the narrow Canons and on North facing steep slopes high up in the Sandia Mts., where it forms dense groves. Very conspicuous in October when the leaves are a bright yellow. New Mexico and Texas is its southern limit from whence it ranges to the Aretic Ocean.

P. Angustrfolia, James. (Narrow-leaved Poplar. Willow-like Poplar. Branches glabrous, leaves alternate at base, glabrous, acute, crenate-serrate. A large tree of the lower part of Bear Canon, often called "Willow.". 'Also grows below Clamp Whitcomb and in other Canons:

63. PIPERACEAE. Pepper Family.

Herbs with pointed stems, alternate entire leaves and perfect, spicate flowers.

\section{Houttứnia, Thunb.}

Perennial herb, spreading by stolons, with thick pungent root; thick leaves with transparent dots; the white flowers crowded in a conical head, (the white part is a bract not a sepal), 6 to 8 stamens.

H. CAlifornica, $B$. and $H$. Stem erect, 2 to 6 in. or more high with a single broad clasping leaf in the center, and an axillary branchlet reduced to one or more slender-petioled leaves; radical leaves oblongoval, cordate.at base, 1 to 6 in. long, glabrous. Exceedingly common in alkili soil in the valley where it often forms a turf.

\section{MONOCOTYLEDONS.}

64. ORCHIDEAE. (ORchis Family.)

Peremials herbs; leaves alternate; flowers perfect and irregular, 6-parted perianth united below with the 1-celled ovary, the 3 sepals and 2 of the petals similar but the third (lip) differing from the others, 1 to 2 stamens borne on the pistil, with pollen waxy and cohering in masses; very numerous and minute seeds.

Whitish or yellowish, leaves reduced to scales,

- - - CoraliorHiza.

With green leaves, -

GOODYERA.

Corallorinza, Haller. (Coral-root.)

The solitary scape has 2 to 4 membranaceous sheaths and a simple raceme of flowers which in ours are yellowish-green or whitish, often mottled with purple. Root thick, resembling a piece of coral, parasitic.

C. multiflora, Nult. 1 to 2 feet high, many-flowered; sepals and petals 3-nerved; lip 3-lobed and bearing a spur which is grown to the ovary; capsule 1-2 to 3-4 in. long. Among the pines, etc. of the Sandia Mountains.

Goodyera, R. Br. Rattlesnake Plantain.

Scapes with a few bracts; leaves thick, arranged in a rosette at the base. Rootstock creeping with fleshy roots.

G. Menziessi, Lindl. Scape pubescent; leaves smooth, ovate-oblong or oblong-lanceolate marked along the main veins with light green markings giving to the leaf a peculiar appearence. Flowers white. Among the Douglas Spruces high up in the Sandias. Not common. In Fern Canon branch of Bear Canon. 65. IRIDEAE. (IrIS FaMILY.

Pernnial herbs, with 2-ranked sheathing leaves; perfect flowers, perianth petal-like, 6-cleft, in two sets of three each, the tube adherent to the 3-celled ovary but above it in ours, 3 distinct stamens.

Iris, Tourn: (Fleur-de-Luce, Flag.)

Stamens beneath the 3 arching petal-like branches of thestyle. Stems from a thick rootstock near the surface of the ground. Flowers pale blue in ours and usually 2 together.

I. Missouriensis, $N u t t$. (Western Iris.)

Stems naked or with 1 or 2 leaves, 6 to 24 in. high; leaves shorter; flower 2 to 3 in. long. Among the oaks of Rim Rock.

\section{LILIACEAE, (LILY Family}

Herbs, or rarely woody plants with regular symmetrical flowers; perianth free from the 3-celled ovary, 6 stamens. Here belongs the Asparagus of the gardens. A. officinalis which frequently runs wild in the valley. F'loral bracts scarious, stamens perigynous.

Flowers in umbells, stems from a bulb,

(1). Alimum.

Flowers in racemes or panicles, no bulb.

Perianth segments many-nerved, leaves thick, fruit a pod,

(2) YUCCA.

Perinath segments 1-nerved.

Fruit a pod, leaves linear, (3) Nolina. (91) 
Fruit a berry; leaves cordate to lenceolate, - - $\because$ (4). VAGNERA.

Floral bracts none or green.

Perianth deciduous, - - (5). Calocontus.

Perianth persistent, - - (6). Zyqadenus.

1. Allium, $L$. (Onion. Garlic.)

Strong-scented pungent, stemless, herbs, from ... a coated bulb; sepals and petals 1-nerved, distinct or united at base; 1-2 black seeds in each cell.

Bulbs cespitose, crowning a rhizome, A. CERNUUM. Bulbs mostly solitary, no rhizome, leaves narrowly linear, flat or channeled

Bulb coats more or less fibrous; several leaves,

- - - - - A. NutTallit.

Bulb coats not fibrous, the outer more or less reticulated, leaves 2 to 4 .

Perianth white with.red mid-vein,

Perianth mostly rose-color, A. STELIATUM. A.cternutu, Roth. (Wild Onion.) Scape naked, angular, 6 to 24 in. high, nodding at apex, beáring a loose or drooping few or many-flowered umbel, leaves flat, linear, sharply keeled, $1 \mathrm{ft}$. Iong; sepals and petals oblong-ovate, rose-color, stamens and style exserted; pod 6 .crested. Bear Canon.

A. Nutrallin, Watson, Scape low, 4 to 6 in. high; bulb very fibrous; perianth segments acute or acuminate, rose-color to white. Sandia Mountains.

A. scaposum, Benth. : (Mesa Onion.) $1 \mathrm{ft}$. high or more; outer bulb-scales dark, with coarse rectilinear veining; umbels loose, rather few-flowered; perianth divisious lanceolate, acuminate 1-4 to $1-3$ in. long, avary not crested. Common on the mesa in spring.

A. Stellatum, Fraser. 6 to 10 inches high, slender; umbel. erect; outer coats of bulb reddish. with linear reticulations, which are very close; perinth segments broad, acute; stamens and style exserted; ovary conspicuously 6-crsted. Rim Rock. July. YUCCA, L. (Spanish Bayonet.)

Stem woody, ours short, bearing the thick evergreen leaves; flowers in a racemose panicle, perianth whitish, campanulate.

Fruit a berry-panicle, sessile, in mountains,

Fruit a capsule, panicle on a scape, - Y. Y. GLACACA.
Y: Baccita, Torr. (Thick-leaved or Mountain Yucea). Stem short or none, leaves coarsely filamentous on the margin, very thick and rigid, 16 to 48 in. long, 1to 2 wide, channeled or concave, with' a very short brown spine. Common in the Pinon Soc. Much eaten by cattle in winter.

Y. Gladca, Fraser. (The Mesa, Y.) Leaves straight and pointed, 1 to $3 \mathrm{ft}$. long and 1-4 to 1-2 in. wide, smooth; raceme usually simple, 1 to $4 \mathrm{ft}$. long, flowers grenish-white or tinged with brown. Very common on the sandier parts of the mesa at the base of the mountains but not extending into them beyond the Candelabria Soc. (Y. angustifolia.) "Amole."

(3). Nolinia, $M x$.

- Trunk cylindrical and stout, leaves' numerous, serrulate; flowering stem bearing compound panicle with very numerous flowers, pedicels solitary; flowers small, polygamo-dioecious, with persistent whitish oblong-lanceolate segments, included stamens; dry and thin in-dehiscent fruit and subglobose light-colored seeds.

N. Texana, Watson. Stems several, 1 to $2 \mathrm{ft}$. high including the panicle, from a very short candex; leaves 2 to $4 \mathrm{ft}$. long (but usually chewed off here) 1-2. in. wide, roughish on the margins covering the ground, panicle compound, the main bracts foliaceous and with dilated bases; pod 1-6 to 1-4 in. broad, on pedicles of about the same length; seed globose ne arly smooth, 1-6 in. broad, bursting the cell. Common on the base of the Sandia Mts., the Manzanellas, etc. Among the rocks, evergreen.

4. Vagnera. False Soloman's-Seal. Also named Smilacina and Unifolium.)

Perennials herbs with simple stemis from a creeping rootstock; alternate, nerved, sessile leaves; white flowers, in a terminal raceme.

V. stellata. Star-like S. S. $1 \mathrm{ft}$, high or less; leaves 7 to 12 , oblong lanceolate, slightly clasping; raceme simple, sessile or nearly so; berries blackish. In Spruce-Acer-Robinia Assn. of Sandia Mts.

5. Calochortus, Pursh. Mountain Tulip. Stems slender; leaves few, linear-lanceolate, the 1-3 cauline alternate clasping, with many nerves; open bell-shaped flowers much the shape of a small tulip; with densely hairy glands; the pod oblong, obtusely angled.

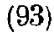




\section{WATSON- Plants of Bernalillo County}

C. Gunnisonr, Watson. Stem with a bulb at base; petals 1.2 to 1.4 in. long, light lilac, yellowish-green below the middle and lined with purple, the transverse gland nearly as broad as the petal. Among the oaks, high up in the Sandia Mts.

\section{Zygadends, $M x$.}

Very smooth perennials, with simple stems from a coated bulb, leaves linear; large-panicled, greenishwhite perfect or polygamous flowers; the sepals petallike; oblong or obovate; with 1 or 2 gland's near the base; stamens free from the sepals and about their length; 3 styles, ovoid conical pod and angled seeds.

Z. Nutraldir, Gray. Stemis 1 to $3 \mathrm{ft}$. high; leaves flat, carinate; racemes rather densely flowered with narrow bracts; perianth free; sepals with an ill-defined gland at base, not at all clawed; seeds 1-4 in. broad. Sandia Mts. July.

Fam. 67, theRushes; 69, the Sedaes (scarce here(; and 70, the Grasses are not treated here as they are difficult for beginners.

68. LEMNACEAE. Duckiveed $F$.

Minute stemless plants, floating free on the water, no differentation of leaf arid stem, but merely a froud with hanging roots underneath. "The blossoms and fruit are rarely seen.

Frond 7 to 11 nerved, with severed rootlets, SpIrodeIa. Frond 1 to 5 nerved, with 1 roptlet, $:-$ LEMñ.

Spirodela poiyrriziza, L. Schleiden. Frond. round-obovate, 1-6 to 1-3 in. long, thick, purple and rather convex beneath, dark green above, palmately mostly 7-nerved. Common in some ponds about the Fair Grounds.

Lempa, minor, $L$. Fronds round to elliptical-obovate, 1-2 to 1-8 in. in diameter. With the last.

7. ALISMACEAE. (Water-plantain Family.

Marsh herbs with fibrous roots, scape-like stems; transversely veined, sheathing petioled radical leasves; perianth of 3 herbaceous persistent sepals, and 3 white deciduous petals; many 1-celled ovaries forming 1seeded achenes.

\section{Sagittaria, L. (Arrow-head.)}

Stoloniferous; juice milky; the leaves often bladeless; stems mostly simple, bearing one or a few whorls of flowers usually in threes. Stamenate above, stamens numerons.

(94)
Bulletin University of New Mexico-No. 49

S. VARIABILIS, Engelm. 4 to 40 in. high; angled stem; leaves very varible but usually sagittate; petals white. "Albuquerqué, Jupne 1st, '99." (Weinzirl.)

72. NAIADACEAE. (PoND-WeED FAMILY.

Immersed aquatic herbs, with l eafy stems. I have an unidentified species of the genus Potamogetor whose flowers occur in spikes and have 4 sepals and 4 stamens. From the reservoir of the Water Supply Co.

73. TYPHACEAE. (CAT-TAIL FAMILY.

Marsh or aquatic herbs with nerved, long-linear, sessile leaves, monoecious flowers in a dense spike.

Typia latifolia, $L$. (Common cat-tail. Too well known to need description. Very common in the valley in swampy places and on the mud flats of the Rio Grande.

\section{GLASS II. GYMNOSPERMS.} 74. GNETACEAE.

Ours shrub, with jointed branches (like a rush); leaves scale like in ours. Stamens monadelphous; a membranous bifid calyx-like perianth, anthers discharge thru a hole at the apex; fertile flowers consist of an ovule with an exserted style, peranth persistent

Ephedra TrIfdrca, Torr. Very common on the mesa especially the western foothills, 1 to $3 \mathrm{ft}$. high. May.

75. CONIFERAE. (Pine Family..)

Evergreen (ours), trées and shrubs with resinous juice; awl-shaped or needle-shaped leaves, entire; monoecious flowers in catkins, no calyx; fruit a cone or berry.

Leaves linear or needle-like. Fruit a cone.

2 to 5 in a cluster, 2 years for cones, (1) Pińus.

Solitary, cones ripening the first year.

Leaves sessile, cones erect, -
Leaves petioled, cones pendulous,

(2) ABits.

(3) $\mathrm{P}$

Leaves scale-like, fruit a berry

$$
\text { 1. PINus, } L \text {. (Pine) }
$$

Leaves 5, each with one fibrorvascular bundle,

$$
\text { - - - - - - - - P. FLEXILis. }
$$

Leaves 2 or 3, each with two fibro vascular bupndles,

Leaves in 2's (rarely 3's), P. EDULIS.

Leaves in 3's (rarely 2's), P. PONDEROSE.

P. FLtexilis, James. (Western "White Pine.)

About 40 to 60 feet high and 3 to 5 feet in diame-

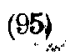


ter when full grown, with furrowed gray bark; leaves: 1.2 t o 2 in. long, subtermnal, light brown with someoval 3 to 5 in. long, subterminal, light brown with somewhat spreading scales only slightly thickened at apex and wkithout priekle or point. On Rim Rock towards North Mountain. Not as common as the others.

P. eudurs, Engelm. (ernon, Nut Pine.)

A low tree 20 to $30 \mathrm{ft}$. high or rarely more; much branched; leaves 1 to 1 1-2 in. long; rigid; spreading, sheathes close cones sessile, subglobose, 2 in. long, tips of the scales thickened but awnless; seeds brown. The commonest pine of the mountains and growing in much more Xerophytic situations than the others. It covers the middle slopes of the Sandia, Manzanellas, and Manzans and most of the country to the east of them:

P. Ponderosa, Doug: (Yellow P. Bull Pine). A large tree said to grow to be $275 \mathrm{ft}$. high and $9 \mathrm{ft}$. in diameter but there are no such giants here; bark reddish brown and very thick, deply furrowed and split into large sections; leaves 5 to 7 in. long; cones oval, $\therefore$ to 5 in. long and 1.6 in. thick, brown, sessile or nearly so and often 3 to 5 together; scales thickened at apex and with a stout recurved prickle. Common low down in the canons and towards the top of the east slope where is also found var scopulorum, which is smaller, leaves 3 to 6 in. long and often in pairs, cones -2 to 3 in. long, grayish brown. The forests towards the south end of Rim Rock are of this variety.

Abies, Luik. Fir.

Conical trees of rapid growth, but wood brittle and decaying quickly; the leaves on the horizontal branches are twisted so as to appear 2-ranked. Ours show 2 longitude resinducts.

A. concolon, Lindl. "Blue Spruce,"

Grows to be 80 to $150 \mathrm{ft}$. high with a diameter of 2 to 4 feet, and a rough gray bark; cones oblong-cylindrical 3 to 5 in: long and 1 to 1.8 in. in diameter; pale green or dull purple, scales 5 to 6 in. wide and only about 1-2 as high. Called also "White Fir." Grows in the canons high up on north-facing slopes and sparingly on Rim 'Rock.

Piseudotsdaa, Carr. Douglas Spruce:

- Quite similar to the last in form but larger and more spreadng with age, from which it differs also in its stomata on the lower surface of the leaf only.
P.pouglasir, Carr. Grows to be 150 to 300 feet high (but not here). and 6 to $9 \mathrm{ft}$. in diameter,' bark very thick, brown, deeply fissured, leaves flat, linear, 1-2 to 1 inch long or more; cones 2 to 4 inches long, subcylindrical, "bracts protruding and spreading giving a fringed appearance to the cones." More common than the last, grows lower down in the canons but t'e fir does not entirely replace it higher up as it ciows even on Rim Rock.

4. Juniperús, $L$. (Juniper. Cedar.)

Shrubs or low trees: Ours have small bluish black berries with a white bloom.

J: Virgindana, L. (Red Cedar. Savin.)

Bark shreddy; wood red and aromatic, leaves opposite, mostly acute with entire margins; berries on straight peduncles; 1 or 2-seeded. Occasional in Sandia Mts. in the Canons; not common as the next nor as stiff.

J. occidentalis, Hook. (Western Cedar.)

Wood pale reddish-yellow; leaves closely appressed, in pairs or more often in 3's, margins delicately fringed; berries .3 to .4 in. in diameter with one or more seds. Very common on the bases of the mountains, wherever rocks outcrop, and there are seattered plants on the Leva Flow. Most of ours'seems to be var, monosperma. (One-seeded Cedar) which has its leaves as often in 2's as 3's and smaller berry usually a single less-grooved seed.

The following genius belong to the Polegonaceae was accidentally omitted:

\section{RUMEX, L. DOCK.}

R. HYMENOSEPalus, torR Canatgre 'Is a low plant with an immense root from which comes a rosette of large leaves in early spring and later a flower stalk. Common in the rich arroyas of the mesa, especially towards the base of the mountains.

$R$. CRISPUS, $L$. CURLED DOCK; So very common in the East, is occasionally seen about town. It is a rather low plant, with a narrow curled leaf.

R. oвtusifolids, $L$. Is also introduced about town. The leaves are broader and not curled.;

R. BERLANDIERI, MEISU, Is the large common dock of the valley, 2 to 3 feet high.

(97) 


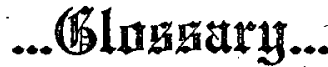

Acaulescent. Stemless or apparently so.

Achene. A small, dry and har̀d, 1-celled, 1-seeded, in indehiscent fruit.

Acuminate. Tapering at the en.

Acute. Terminating with a sharp or well-defined angle.

Adnate. United, as the inferior ovary with the calyxtube. Adnath anther, one attached for its whole length to the inner or outer face of the filament.

Adventive. Recently or omperfectly naturalized.

Albumen. Any deposit of nutritive material accom panying the embryo.

Alternate. Not opposite to each other, as sepals and petals, or as leaves upon a stem.

Ament. A catkin, or peculiar scaly unisexual spike.

Annular. In the form of a ring.

Anterior. On the front side of a flower and next the bract, remote from the axils of inflorencence; equivalent to inferior and (less properly) exterior.

Antheriferous. Anther-bearing.

Apetalous. Having no petals.

Apiculate. Ending in a short pointed tip.

Appressed. Lying close and flat against.

Arachnoid. Cobwebby; of slender entangled hairs.

Articulate. Jointed; having a node or joint.

Ascending. Rising somewhat obliquely, or curving upward.

Ascending ovule. one that is attached above the base of the ovary and is directed upward.

Attenuate. Slenderly tapering; becoming very narrow.

Auricle. An ear-shaped appendage.

Auriculate. Furnished with auricles.

Awl-shaped. Narrowed upward from the base to a slender or rigid point.

A w'n. A bristle-shaped appendage.

Axillary. Situated in the axis.
Bifid. Two-cleft.

Bract. A more or less modified leaf subtending a flower or belonging to an inflorescence, or sometimes cauline.

Braceate. Having bracts.

Caducous. Falling off very early.

Calyculate. - Having bracts around the calyx imitating an outer calyx.

Campanulate. Bell-shaped; cup-shaped with a broad base.

Canescent. Hoary with gray pubescence.

Capitate. Shaped like a head; collected into a head or dense cluster.

Capsule. A dry dehiscent fruit composed of more than one carpel; the spore-case of Hepaticae, etc.

Carpel. A simple pistil, or one member of a compound pistil.

Cartitaginous. Of the texture of cartilage; firm and tough.

Caudate. Having a slender tail-like appendage.

Caudex. The persistent base of an otherwise annual herbaceous stem.

Caulescent. Having a manifest stem.

Cespitose. Growing in tufts; forming mats of turf.

Ciliate. Marginally fringed with hairs.

Cinerous. Ash-color.

Circumscissile. Dehiscing by a regular transverse circular line of divsion.

Clavate. Club-shaped; gradually thickened upward. Cleft. Cut about to the middle.

Comose. Furnished with a como or tuft of hars.

Connate. United congenitally.

Cordate. Heart-shaped with the point upward.

Corymb. A flat-topped or convex open flower-cluster, in the stricter use of a word equivalent to a contracted raceme and progressing in its flowering from the margin inward.

Corymbose. .In corymbs, or corymb-like.

Crenate. Dentate with the teeth much rounded.

Crown: An inner appendage to a petal, or to the throat of a corolla.

Cucullate. Hooded or hood-shaped; cowled.

Cuneate. Wedge-shaped; triangular with the acute angle downward. 
W'ATSON-Plants' of Bernalillo County

Cuspidate. Tipped with acusp, or sharp and rigid point.

Cyme. A usual broad and flatish dèterminate infloencence, $\dot{i}$. e. with central or treminal flowers blooming" eärliest.

Cymose. Bearing cymes or cyme-like.

Decumbent. Reclining, but with the summit ascending.

Decurrent (leaf. Extending down the stem below the insertion.

Dehiscent. Opening regularly by valves; slits, etc.," aś a capsule or anther.

Dentàte. Toothed, usually with the teeth directed outward.

Diadelphous (stamens). Combined in two sets.

Dichotomous. Forking regularly by pairs.

Didynamous (stamens). In two pairs of unequal length.

Dioecious. Unsexual, with the two kinds of flowers on separate plants.

Dorsal. Upon or relating to the back or outer surface of an organ.

Drupe. A fleshy or pulpy fruit with the inner portion of the pericarp (1-celled and 1-sedeed, or sometimes several-celled) hard or stony.

Exserted. Projecting beyond an envelope, as stamens from a corolla.

Falcate. Scythe-shaped; curved and flat, tapering gradually.

Foliaceous. Leaf-like in texture or appearance.

Fornicate. Arched over, as the corona of some Borraginaceae, closing the throat.

Fugacious. Falling or fading very e arly .

Gibbous. Protuberant or swollen on one side.

Glabrate. Somewhat glabrous, or becoming glabrous.

Hirsute. Pubescent with rather coarse or stiff hair.

Hispid. Beset with rigid or bristly hairs or with bristles.

Hoary. Grayish-white with a fine close pubescence.

Incised. Cut sharply and irregularly, more or less deeply.

Included. Not at all protruded from the surrounding envelope.

Inferior. Lower or below; outer or anterior.
Bulletin University of New Mexico-No. 49

Involucle. A secondary involucre, as that of an umbellet in Umbelliferae.

Lanceolate. Shaped like a lance-head, broadest above the base and narrowed to the apex.

Lenticular. Lental-shaped; of the shape of a doubleconvex lens.

Loculicidal. Dehiscent into the cavity of a cell thru the dorsal suture.

Lyrate. Pinnatifid: with. a large and rounded terminal lobe, and the lobes small.

Monadelphous. (stamens). United by their filaments into a tube or column.

Monaecious. With stamens and pistils in separate flowers on the same plant.

Mucro. A short and small abrupt tip.

Mucronate. Tipped with a mucro.

Ob. A Latin prefix, usually carrying the idea of in version.

Ochroleuceous. Yellowish white.

Ovate. Egg-shaped; having an outline like that of an egg, with the broader end downward.

Pedicel. The support of a simple flower.

Peduncle. A primary flower-stalk, supporting ether a cluster or a solitary flower.

Puberulent. Minutely pubescent.

Pubescent. Covered with hairs, especially if short, soft and downy.

Pungent. Terminating in a rigid sharp point; acrid.

Raceme. A simple inflorescence of pedicelled flowers. upon a common more or less elongated axis.

Racemose. In racemes; or res emblng a raceme.

Radical. Belonging to or proceeding from the root or

base of the stem near the ground.

Regular. Uniform in shape or structurè.

Rotate (corolla). Wheel-shaped; flat and circular in outline.

Rugose. Wrinkled.

Salver-shaped (corolla). Having a slender tube abruptly expanded into a flat limb.

Scape. A peduncle rising from the ground.

Scapose. Bearing or resembling a scape:

Scarious. Thin, dry, and membranaceous, not green. Septicidal (capsule).-Dehiscing through the partitions and between the cells.

Serrate. Having teeth pointing forward.

(101) 


\section{W'ATSON-Plants of Bernalillo County}

Serrulate. Finely serrate.

Sinnate. With the outline of the margin strongly wavy Spike... A form of simple inflorescence with the flowers sessile or nearly so upon a more common axis:

Succulent. Juicy; fleshy.

Tetradynamous. Having four long and two shorter stamens.

Tomentose. Densely pubesecent with matted wool.

Villous: Bearing long and soft hairs:

Viscid. Glutinous; sticky:

Whorl: Ari arrangement of leaves; etc, in à circle round thestem.

\section{Bulletin University of New Mexico-No. 49}

\section{INDEX}

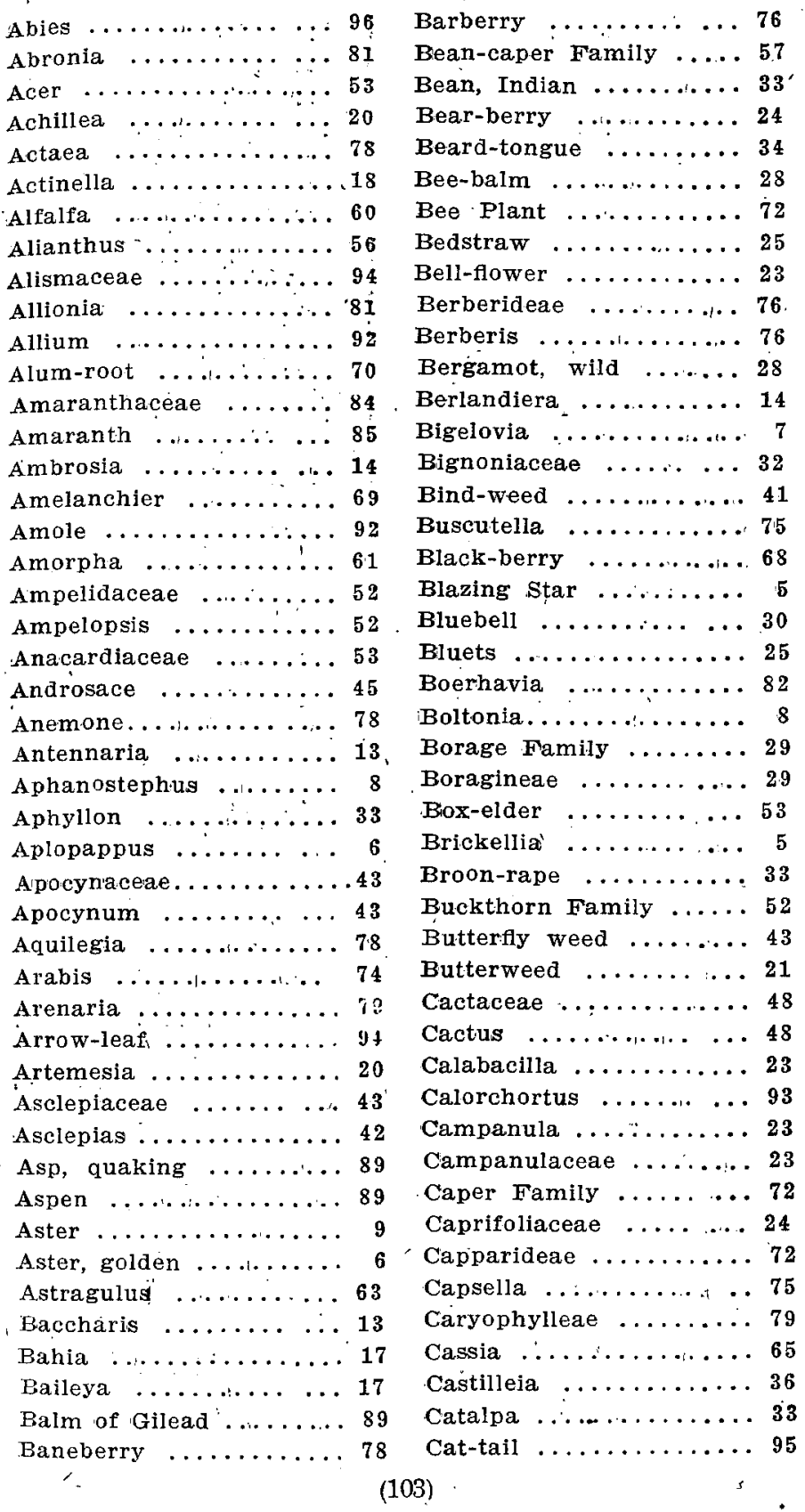




\begin{tabular}{|c|c|c|}
\hline & & \\
\hline dar $\ldots \ldots, \ldots \ldots$ & 97 & Dandelion \\
\hline edronella $\ldots: \cdots:: \cdots \ldots$ & 29 & Dandelion, Fr \\
\hline trineae $\ldots \ldots \ldots$ & 52 & 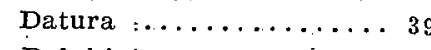 \\
\hline$\ldots \ldots, \cdots \cdots, \ldots$ & 87 & Delphinium . . \\
\hline$y \quad \ldots \ldots \ldots \ldots$ & 44 & Desert Willow \\
\hline çarpus .......... & 68 & Dock $\ldots \ldots \ldots \ldots \ldots$ \\
\hline$\ldots \ldots \ldots \ldots \ldots$ & 49 & \\
\hline saracha..$\ldots \ldots$ & 38 & ne $\ldots . \ldots \ldots$. \\
\hline diaceae $\quad . \ldots \ldots$ & 82 & $\mathrm{ur} \quad \ldots \ldots \ldots \ldots \ldots$ \\
\hline opodium ...... & $8: 4$ & $a \ldots \ldots \ldots \ldots$ \\
\hline ry $\quad \ldots \ldots \ldots \ldots \ldots$ & 67 & Need Family .... \\
\hline ry, ground $\ldots \cdots \cdots$ & 38 & $\ldots \ldots \ldots \ldots$ \\
\hline$\cdots \cdots \cdots \cdots$ & 79 & permum ...... \\
\hline$\ldots \ldots \ldots \ldots$ & 33 & delabria...... \\
\hline sis $\quad \ldots \ldots \ldots \ldots$ & 6 & $\ldots \ldots \ldots \ldots$ \\
\hline$i 1 \ldots \ldots \ldots \ldots \ldots$ & 68 & \\
\hline$r_{s} \ldots \ldots \ldots \ldots \ldots$ & 25 & \\
\hline latis $\ldots \ldots \ldots \ldots . \quad$. & 77 & \\
\hline ne $\ldots \ldots \ldots \ldots \ldots$ & 72 & \\
\hline$\ldots \ldots \ldots \ldots \ldots$ & 75 & \\
\hline$\ldots \ldots \ldots \ldots$ & 60 & bia $\ldots \ldots \ldots \ldots$ \\
\hline weet $\ldots \ldots \ldots$ & 60 & laceae...$\ldots$. \\
\hline$\ldots \ldots \ldots \ldots \ldots$ & 21 & ing $\ldots \ldots \ldots \ldots$ \\
\hline False $\ldots \ldots \ldots$. & 18 & us $\ldots \ldots \ldots \ldots$. \\
\hline bur,$\ldots \ldots \ldots$. & 15 & a ............ \\
\hline$n$ bine $\ldots \ldots \ldots \ldots$ & 78 & $\cdots \cdots \cdots$ \\
\hline ndra $\ldots \ldots \ldots \ldots$ & 87 & e....... \\
\hline ae $\ldots \ldots \ldots \ldots$ & 1 & . Family ... . . . . \\
\hline$\ldots \ldots \ldots \ldots$ & 95 & $\ldots \ldots \ldots \ldots \ldots$ \\
\hline laceae $\ldots \ldots \ldots$ & 41 & ger $\ldots \ldots \ldots 6$ \\
\hline$a \ldots \ldots \ldots \ldots$ & 90 & eria $\ldots \ldots \ldots \ldots \ldots$ \\
\hline ot $\quad \ldots \ldots \ldots$ & 90 & $\ldots \ldots \ldots$ \\
\hline$\ldots \ldots \ldots \ldots \ldots$ & 76 & $\mathrm{Fl}$ \\
\hline od $\quad \because \ldots \ldots \ldots$ & 89 & \\
\hline atae............. & 72 & $r$ de lis $\ldots \ldots \ldots . .$. : \\
\hline$\cdots \cdots \cdots \cdots \cdots$ & 74 & Four O'clock Family .....8 8 \\
\hline$\ldots \ldots \ldots \ldots$ & 55 & garia.......... 6 \\
\hline ot Family $\ldots \ldots$ & 76 & a $\ldots$ \\
\hline $\operatorname{ard} \ldots \ldots \ldots \ldots$ & 17 & iceae $\ldots \ldots \ldots \ldots$ \\
\hline$e^{\prime} \ldots \ldots \ldots$ & 73 & y Family ...... \\
\hline$\ldots \ldots \ldots \ldots$ & 23 & dia $\ldots \ldots \ldots \ldots$ \\
\hline aceae $:: \cdots \cdots$ & 23 & 然 \\
\hline 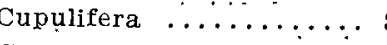 & 88 & $\ldots \ldots \ldots 4$ \\
\hline 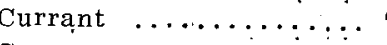 & 72 & Ger \\
\hline$\cdots: \cdots_{\cdots}$ & 42 & \\
\hline & 8 & \\
\hline & & \\
\hline
\end{tabular}
(104)

\begin{tabular}{|c|c|}
\hline & sae \\
\hline$\ldots \ldots \ldots \ldots 6-7$ & ae... \\
\hline olden-rod, Rayless $\ldots$. & \\
\hline blden-rod, Western $\because \therefore 6$ & $1 y s-\ldots \ldots$ \\
\hline era $\ldots \ldots \ldots: \ldots 1$ & \\
\hline rry $\ldots \ldots \ldots \ldots \cdot 71$ & \\
\hline se-foot $\ldots \ldots \ldots \cdot 84$ &.$\ldots \ldots \ldots$ \\
\hline $\operatorname{ard} \ldots \ldots \ldots \ldots \ldots 23$ & \\
\hline$e^{\prime} \ldots \ldots \ldots \ldots \ldots 2$ & \\
\hline alerian .......4 & \\
\hline $00 d . \ldots \ldots \ldots: 84$ & (5) \\
\hline Cherry ...... 38 & \\
\hline el . ........... 21 & mum ... \\
\hline el-tree $\ldots \ldots \ldots \ldots$ 13 & \\
\hline ia $\ldots \ldots \ldots \ldots, 6$ & ( \\
\hline nia $\ldots \ldots \ldots \therefore 16$ & antain $\ldots .$. \\
\hline erms $\quad \ldots \ldots \ldots .95$ & $\ldots \ldots \ldots \ldots$ \\
\hline$\ldots \ldots \ldots \ldots 87$ & ss. Ver \\
\hline$\ldots \ldots \ldots \ldots \ldots 41$ & \\
\hline $\operatorname{ed} \ldots \ldots \ldots \ldots \ldots, \ldots 22$ & e $\ldots$ \\
\hline$\ldots \ldots \ldots \ldots \ldots 27$ & \\
\hline us $\ldots \ldots \ldots \ldots 16$ & \\
\hline um $\ldots \ldots \ldots \ldots 29$ & LJ \\
\hline Iian $\ldots \ldots \ldots .43$ & \\
\hline$\ldots \ldots \ldots \ldots \ldots 70$ & untain... \\
\hline$m \cdots \ldots \ldots$ & mily $\ldots \ldots \ldots$ \\
\hline 28 & \\
\hline eggia $\ldots \ldots \ldots \ldots 65$ & ia $\ldots \ldots \ldots$. \\
\hline kle Family .... 24 & \\
\hline$=\therefore \ldots \ldots \ldots \ldots 56$ & d, Fetid .. \\
\hline$a \ldots \ldots \ldots \ldots .25$ & $a \ldots \ldots \ldots$ \\
\hline ia............90 & y Bush. \\
\hline laceae ........ & a......... \\
\hline herium .......19 & Rue $\ldots \ldots$ \\
\hline pappus $\ldots \ldots \ldots 18$ & -sweet \\
\hline Talse $\ldots \ldots \ldots$ & gium .... \\
\hline$\ldots \ldots \ldots \ldots \ldots$ & \\
\hline$\ldots \ldots \ldots \ldots \ldots \ldots$ & $\cdots \cdots \cdots$ \\
\hline nerican ...... & $\cdots \cdots$ \\
\hline adder..... & \\
\hline$\ldots \ldots \ldots \ldots$ & \\
\hline weed........... & $\ldots \ldots \ldots$ \\
\hline$r r y \ldots \ldots \ldots \ldots 69$ & \\
\hline$\cdots \ldots \ldots \ldots$ & ily . \\
\hline$\ldots \ldots \ldots$ & \\
\hline kia $\ldots \ldots \ldots \ldots$ & oe, false. \\
\hline ae $\ldots \ldots \ldots$. & $\ldots \ldots \ldots$ \\
\hline 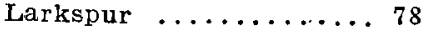 & \\
\hline & \\
\hline
\end{tabular}

(105)

\author{
98 \\ 20
}




\begin{tabular}{|c|c|c|}
\hline & & \\
\hline$\ldots \ldots$ & 71 & \\
\hline$\ldots \ldots \ldots \ldots$ & 28 & \\
\hline key flower ........ & 36 & Pigweed, Winged \\
\hline otyledons........ & 90 & Pine $\ldots \ldots \ldots .$. \\
\hline ustard Family $\ldots \ldots \ldots$ & & Pink Family . \\
\hline ard, Tansy $\ldots . .$. & 74 & Pinon......... \\
\hline $\operatorname{ama} \ldots \ldots \ldots \ldots \ldots$ & 32 & Pinus $\ldots \ldots \ldots$ \\
\hline asturtium $\quad \ldots \ldots \ldots \ldots$ & 74 & Piperace \\
\hline $10 \ldots \ldots \ldots \ldots \ldots$ & 53 & neae. \\
\hline e Family ......... & 87 & in $\ldots \ldots \ldots \ldots$ \\
\hline e, Horse $\ldots \ldots \ldots$ & 39 & ain, Rattlesnak. . \\
\hline ceae $\ldots \ldots \ldots \ldots \ldots$ & 95 & go. $\ldots \ldots \ldots \ldots$ \\
\hline na $\ldots \ldots \ldots \ldots$ & 33 & Pola \\
\hline ade $\quad \ldots \ldots \ldots \ldots 37$ & 37 & pae. \\
\hline ark $\ldots \ldots \ldots \ldots \ldots 68$ & 68 & $2 \ldots \ldots \ldots$ \\
\hline$\ldots \ldots \ldots \ldots \ldots 93$ & 93 . & ol \\
\hline neae $\ldots \ldots \ldots .88$ & 80 & ae $\ldots$ \\
\hline$\ldots \ldots \ldots$ & 88 & $n \ldots . .$. \\
\hline$\ldots \ldots \ldots \ldots$ & 46 & $\$ \ldots \ldots$ \\
\hline rariae $\ldots \ldots \ldots$ & 45 & Pond \\
\hline$\ldots \ldots \ldots \ldots \ldots \ldots$ & 92 & \\
\hline$\ldots \ldots \ldots \ldots$ & 50 & \\
\hline mily.$\ldots \ldots .90$ & 90 & \\
\hline$\ldots \ldots \ldots \ldots$ & 90 & ceae. \\
\hline ceae $\ldots . . . \ldots$ & & Pot \\
\hline nily $\ldots \ldots \ldots$ & 72 & $\ldots \ldots$ \\
\hline rhiza $\ldots \ldots \ldots$ & 48 & ver $\ldots$. \\
\hline$\therefore \ldots \ldots \ldots \ldots$ & 58 & eae $\ldots .$. \\
\hline royo $\ldots . . .$. & 14 & $\therefore \ldots \ldots$ \\
\hline us $\ldots \ldots \ldots \ldots$ & & e, Evening \\
\hline $\mathrm{s} \ldots \ldots \ldots \ldots$ & 63 & se, $\operatorname{Fam} . \ldots \ldots$ \\
\hline na $\ldots \ldots \ldots . . .$. & 52 & Pru \\
\hline p $\ldots \ldots \ldots$ & 36 & suga $\ldots$ \\
\hline er......... & 78 & $s \ldots \ldots \ldots$ \\
\hline$n \ldots \ldots \ldots$ & 14 & Psol \\
\hline$y \ldots \ldots \ldots$ & 58 & Pte \\
\hline kly $\ldots \ldots \ldots$ & 50 & \\
\hline$\cdots \ldots, \ldots: \cdots$ & 20 & e $\ldots \ldots \ldots$ \\
\hline neae $\ldots \ldots \ldots$. & 33 & , sea $\ldots$ \\
\hline daris $\ldots \ldots \ldots \ldots$ & 36 & pappus \\
\hline Mock ..... & 27 & \\
\hline$\therefore \ldots \ldots \ldots$ & 34 & \\
\hline ass $\ldots \ldots \ldots$ & 75 & d Spiny $:$. \\
\hline $10 n \ldots . . . \ldots \ldots$ & 62 & laceae .. \\
\hline$\ldots \ldots \ldots \ldots$ & 31. & \\
\hline$s \quad \ldots \ldots \ldots$ & 70 & \\
\hline ron.......... & & less Golden-rod \\
\hline & & \\
\hline
\end{tabular}

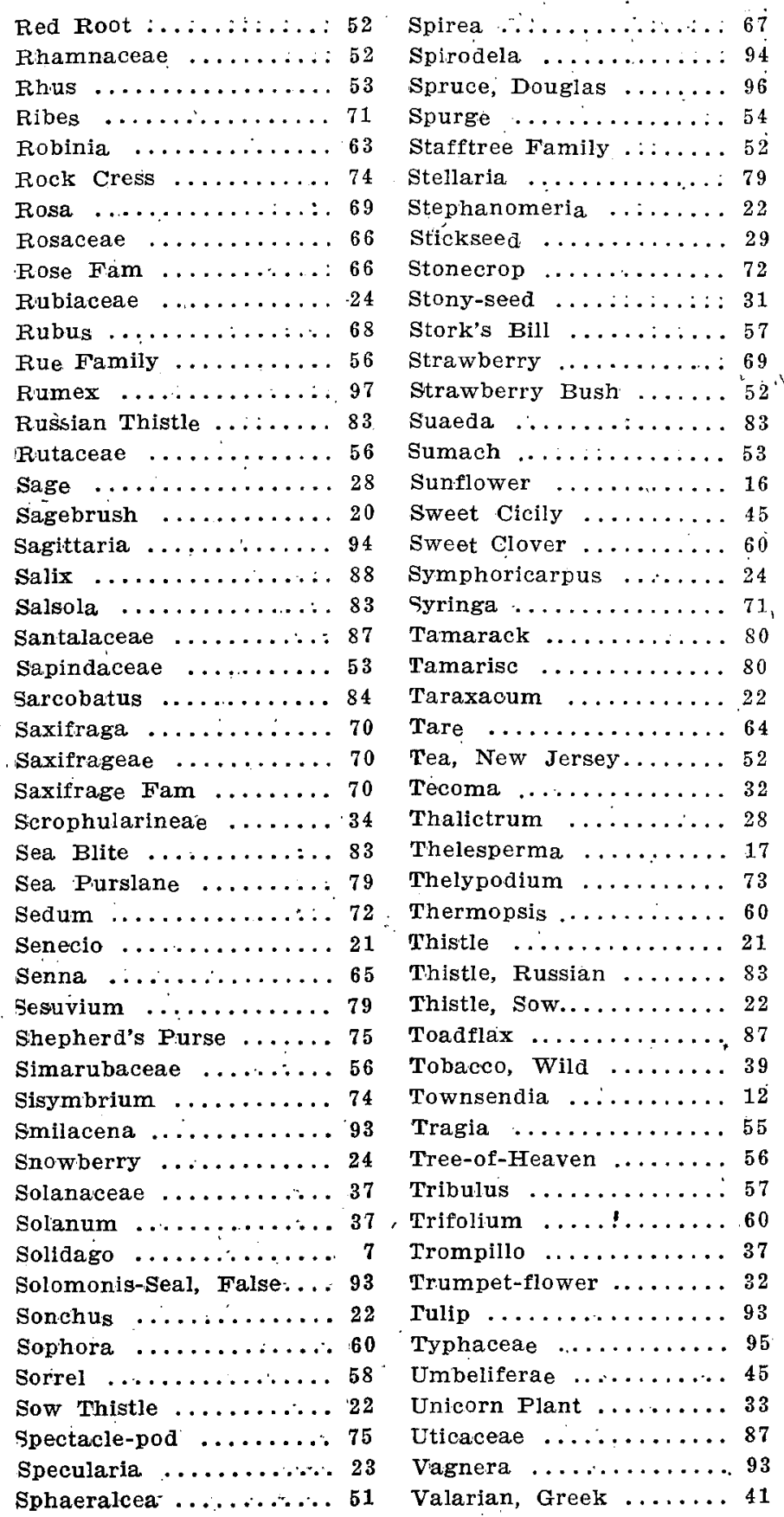

(107) 


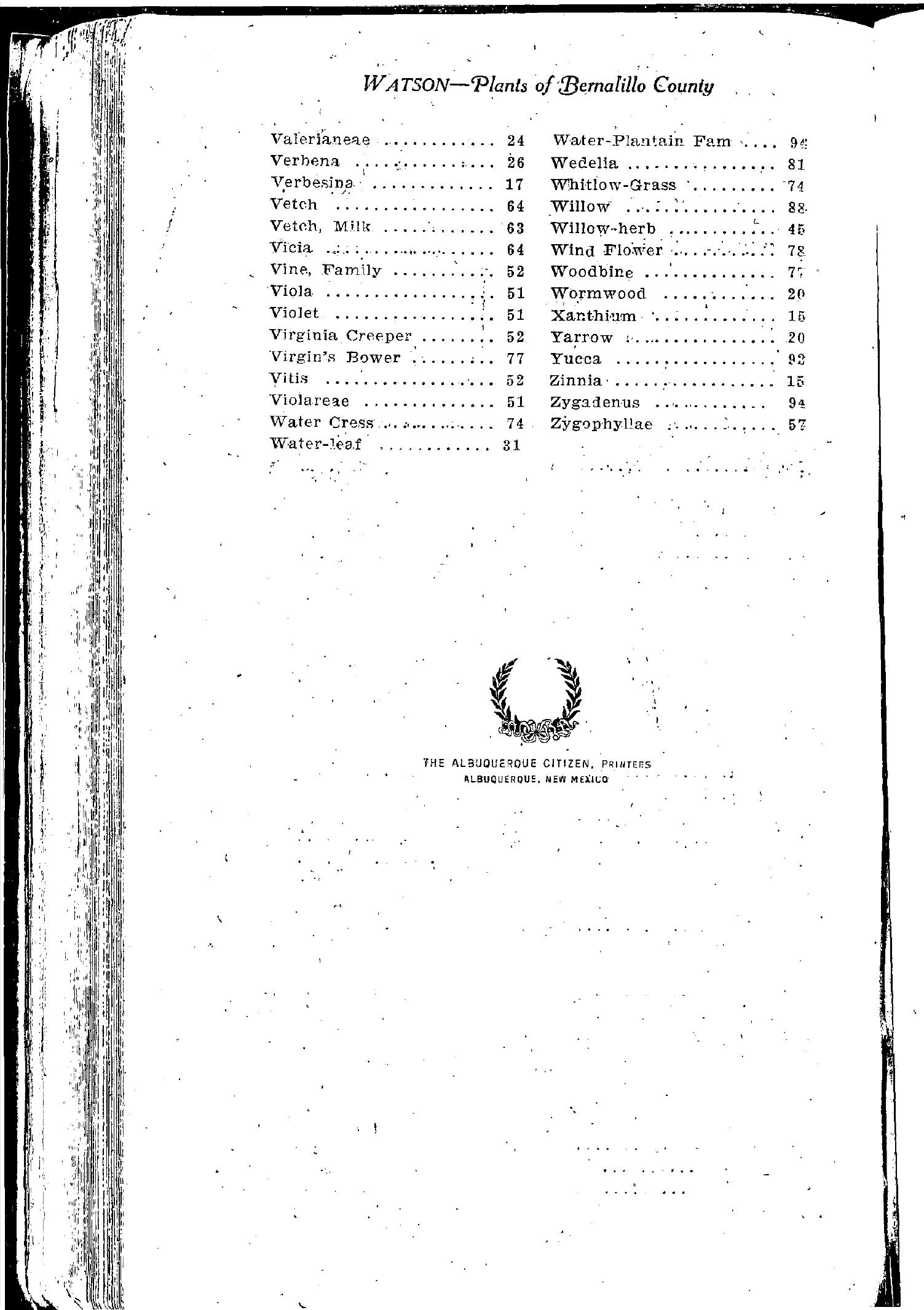

